\title{
UTILIZAÇÃO DE SULFETO COMO DOADOR DE ELÉTRONS PARA A DESNITRIFICAÇÃO AUTOTRÓFICA APLICADA AO TRATAMENTO DE ESGOTO SANITÁRIO
}

Dissertação apresentada à Escola de Engenharia de São Carlos, da Universidade de São Paulo, como parte dos requisitos para a obtenção do título de Mestre em Engenharia Hidráulica e Saneamento

ORIENTADOR: PROF. TIT. EUGENIO FORESTI 

AUTORIZO A REPRODUÇÄO E DIVULGAÇÄO TOTAL OU PARCIAL DESTE TRABALHO, POR QUALQUER MEIO CONVENCIONAL OU ELETRÔNICO, PARA FINS DE ESTUDO E PESQUISA, DESDE QUE CITADA A FONTE.

Ficha catalográfica preparada pela Seção de Tratamento da Informação do Serviço de Biblioteca - EESC/USP

M827u

Moraes, Bruna de Souza

Utilização de sulfeto cono doador de elétrons para a desnitrificação autotrófica aplicada ao tratamento de esgoto sanitário / Bruna de Souza Moraes ; orientador Eugenio Foresti. -- São Carlos, 2009.

Dissertação (Mestrado) - Programa de Pós-Graduação e Area de Concentração em. Hidráulica e Saneamento -Escola de Engenharia de São Carlos da Universidade de São Paulo.

1. Nitrogênio - remoção. 2. Desnitrificação autotrófica. 3. Sulfeto. 4. Doador de elétrons. 5. Modelagem cinética. 6. Transferência de massa.

7. Esgotos sanitários. I. Título. 

FOLHA DE JULGAMENTO

Candidata: Engenheira BRUNA DE SOUZA MORAES

Dissertação defendida e julgada em 20/02/2009 perante a Comissão Julgadora:

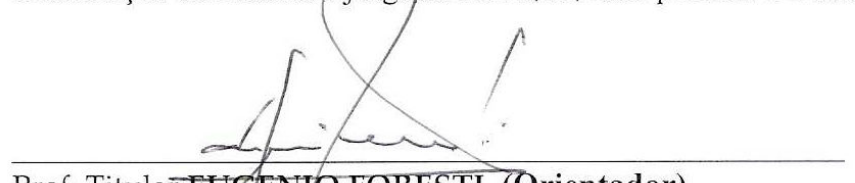

Prof. Titular EUGENIO FORESTI (Orientador)

Afrovada

(Escola de Engenharia de São Carlos/USP)

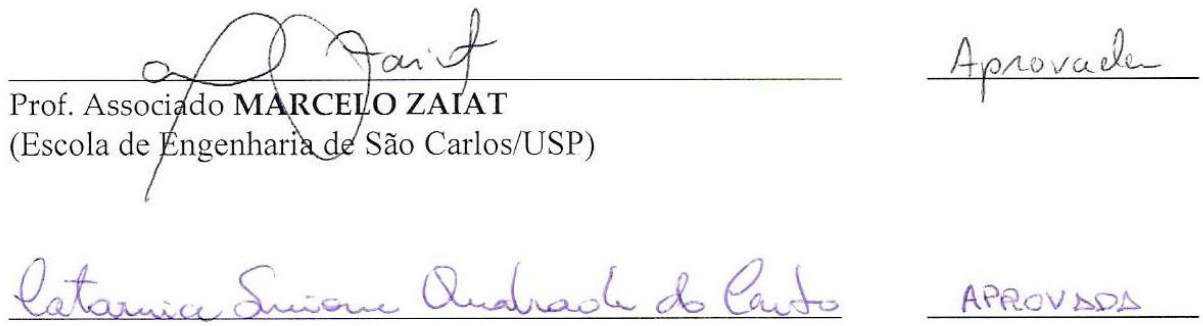

Profa. Dra. CATARINA SIMONE ANDRADE DO CANTO

(Instituto Mauá de Tecnologia/EEM)
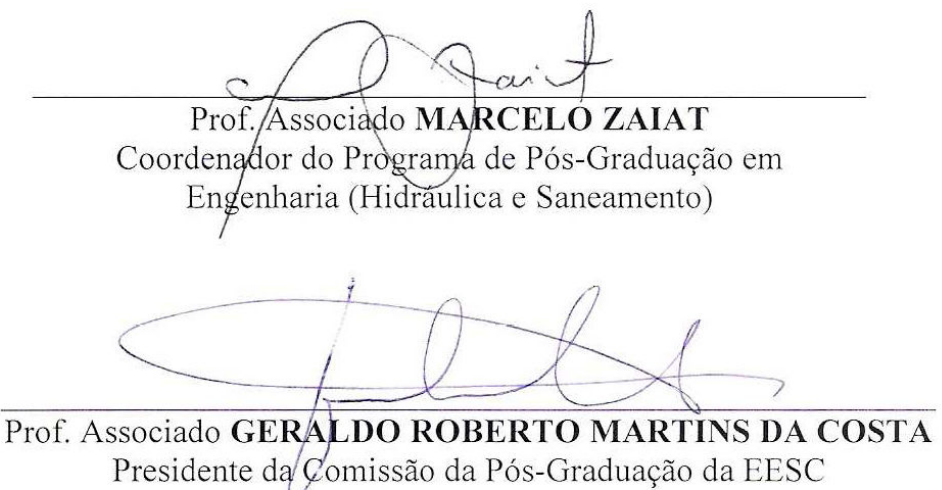

Mos meus pais Pedro e Cisela, a minha irmã Évica e ao meu querido. Forge, pelo apoio, confiansa, amor e amizade incansáveis e infundáweis. 



\section{AgRADECIMENTOS}

Agradeço a Deus, acima de tudo, por me guiar e iluminar meus caminhos durante esta longa jornada.

À minha querida família, em especial Pedro, Gisela, Érica, Vó Diva e Vô Pedro, pelo carinho, dedicação, apoio e incentivo constantes... amo vocês!

Ao meu Jorginho, pelo amor, confiança, paciência e dedicação... te amo! Salve Jorge!

Ao professor Dr. Eugenio Foresti, pela confiança e amizade concedidas, por todos ensimanentos transmitidos (e foram muitos!), e por orientar este trabalho com sabedoria e excelência.

Ao professor Dr. Marcelo Zaiat, pela grande colaboração, auxílio e sugestões para elaboração e conclusão da dissertação, e pela generosa amizade.

À professora Dra. Maria Bernadete, pelo auxílio e sugestões durante a etapa experimental, principalmente a respeito da microbiologia.

À professora Giovana e à Márcia, pelas críticas e sugestões muito bem vindas nos exames de qualificação.

Às minhas queridíssimas "roommates", Ana Flávia e Renata (minha "revisora particular"!), e ao grande companheiro de experimentos, Theo, pela profunda amizade construída, pelas risadas e bons momentos em São Carlos, e por estarem sempre presentes, apoiando e ajudando em tudo que podiam (vocês estarão para sempre no meu coração!).

Aos amigos e colegas de laboratório, em especial a Dani, Tiagão, Júlia, Isabel, Kátia, Regiane, Sandra e Carol.

A todos os amigos das disciplinas, em especial à Juliana, Rafael e Ricardo.

Às funcionárias do Laboratório de Processos Biológicos Janja e Eloísa pela constante disposição em me auxiliar quando precisei durante a fase experimental desta pesquisa.

Às secretárias do Curso de pós-graduação em Hidráulica e Saneaemento, Rose, Sá e Pavi, pelas informações e por todo auxílio.

Ao CNPq por parte da bolsa de mestrado concedida.

À FAPESP pela bolsa e pelo auxílio finaceiro concedidos.

A todos aqueles que contrubuíram, direta ou indiretamente, para a realização deste trabalho. 

"O conhecimento é orgulhoso por ter aprendido tanto; a sabedoria é humilde por não saber mais.

"Avida éuma pesa de teatro que não permite ensaios. Par isso cante, ria, dance, chore e viva intensamente cada momento de sua vida, antes que a cortina se feche e a pesa termine sem aplausos." (Gharles Ghaplin) 



\section{RESUMO}

MORAES, B.S. (2009). Utilização de sulfeto como doador de elétrons para a desnitrificação autotrófica aplicada ao tratamento de esgoto sanitário. Dissertação (Mestrado) - Escola de Engenharia de São Carlos, Universidade de São Paulo.

A presente pesquisa teve, por principal objetivo, avaliar a viabilidade da desnitrificação autotrófica, empregando sulfeto como doador de elétrons, aplicada a efluentes de reatores anaeróbios tratando esgoto sanitário. Estudos anteriores indicam que o sulfeto presente na fase líquida de efluentes e no biogás pode ser utilizado como doador de elétrons para a desnitrificação. Porém, há poucas informações sobre as interações entre os ciclos do carbono, nitrogênio e enxofre neste processo que permitam a utilização prática dos fundamentos já conhecidos sobre a desnitrificação na presença de sulfeto. Neste trabalho, realizaram-se ensaios de desnitrificação na presença de sulfeto, a fim de se avaliar o potencial de uso desse composto como doador de elétrons. Inicialmente, foram utilizados frascos de $1 \mathrm{~L}$ contendo biomassa imobilizada em espuma de poliuretano, alimentados com meio sintético nitrificado contendo sulfeto como doador e nitrito e nitrato como receptores de elétrons. Variou-se a concentração de sulfeto, obtendo-se diferentes relações N/S. Constatou-se desnitrificação completa de ambos os receptores estudados; entretanto, isto só ocorreu com estabilidade para relações $\mathrm{N} / \mathrm{S}$ inferiores à relação estequiométrica baseada nas reações químicas correspondentes, isto é, quando foi aplicado sulfeto em excesso. Os resultados mostraram que a oxidação total ou parcial dos compostos de enxofre no processo depende da relação N/S, e a velocidade de consumo de nitrato foi maior que a de nitrito. Posteriormente, realizaram-se novos ensaios semelhantes ao anterior, porém, a alimentação consistiu na mistura do efluente sintético nitrificado a efluente de reator anaeróbio tratando água residuária de abatedouro de aves, e o único receptor de elétrons aplicado foi nitrato. Neste caso, foi constatada desnitrificação completa na relação N/S correspondente à estequiometria relativa a sulfeto e nitrato. A cinética de remoção de nitrogênio seguiu modelo de decaimento exponencial de primeira ordem; entretanto, houve limitação à transferência de massa intraparticular e na fase líquida, fato que caracterizou os modelos ajustados como sendo de primeira ordem. As velocidades específicas aparentes obtidas na primeira fase foram próximas de $15 \mathrm{mgN} \cdot \mathrm{gSSV}^{-1} \cdot \mathrm{h}^{-1}$, tanto com a aplicação de nitrato, quanto de nitrito como receptores de elétrons. Na segunda fase, a máxima velocidade específica aparente de remoção de nitrato foi da ordem de $6 \mathrm{mgN} \cdot g \mathrm{SSV}^{-1} \cdot \mathrm{h}^{-1}$.

PALAVRAS-CHAVE - Remoção de nitrogênio, desnitrificação autotrófica, sulfeto, doador de elétrons, modelagem cinética, transferência de massa, esgoto sanitário 


\section{Abstract}

MORAES, B.S. (2009). Utilization of sulfide as electron donor in autotrophic denitrification applied to treatment of domestic sewage. MSc. Dissertation, Escola de Engenharia de São Carlos - Universidade de São Paulo.

The feasibility of autotrophic denitrification of effluent from anaerobic reactor treating domestic sewage using sulfide as electron donor was evaluated. Prior researches reveals sulfide into liquid phase of effluents and biogas can be utilized as electron donor for denitrification. However, information about the interaction between carbon, nitrogen and sulfur cycles in this process are few to permit practice utilization of known fundamentals about denitrification in presence of sulfide. In this work, laboratory tests of denitrification in the presence of sulfide were carried out to evaluate potential employ of this compound as electron donor. Initially, 1 L flasks with immobilized biomass in polyurethane foam was fed with synthetic nitrified wastewater containing sulfide as donor and nitrite e nitrate as electron acceptors. Sulfide concentration was diversified to obtain different N/S ratios. Complete denitrification occurred with nitrate and nitrite; nevertheless, it was observed in a stable way only for $\mathrm{N} / \mathrm{S}$ ratios smaller than stoichiometric rate based in the corresponding chemistry reactions, that is, when applied excess of sulfide. The results showed that total or partial sulfur compounds oxidation depends on N/S ratio and the nitrate removal rate was bigger than nitrite removal rate. Afterward, new assays were carried out in the same way. However, the flasks were fed with synthetic nitrified wastewater mixed to effluent from anaerobic reactor treating bird slaughterhouse wastewater, and nitrate was the only electron acceptor applied. In this case, complete denitrification was evidenced for stoichiometric N/S ratio relating to sulfide and nitrate. Nitrogen removal kinetic followed exponential decay model of first order; however, this behavior was due to mass transfer limitation in the liquid phase and intraparticular. Apparent specific rates of nitrogen removal found in the first phase were nearby $15 \mathrm{mgN} \cdot g \mathrm{gSV}^{-1} \cdot \mathrm{h}^{-1}$, with nitrate as well as nitrite application. In the second phase, maxima apparent specific rate of nitrogen removal in nitrate form was about $6 \mathrm{mgN} \cdot \mathrm{gSSV}^{-1} \cdot \mathrm{h}^{-1}$.

KEYWORDS - Nitrogen removal, autotrophic denitrification, sulfide, electron donor, kinetic modelling, mass transfer, domestic sewage 


\section{LISTA DE FIGURAS}

Figura 1 - Distribuição das formas de sulfeto para diferentes valores de $\mathrm{pH}$ : $(\nabla)$ faixa de $\mathrm{pH}$ da digestão anaeróbia e $(\mathbb{\mathbb { N }}) \mathrm{pH}$ ótimo para digestão metanogênica.

Figura 2 - Fluxograma do procedimento experimental 18

Figura 3 - Reatores desnitrificantes operados em batelada (RI1, RI2, RI3).

Figura 4 - Morfologias observadas sob microscopia óptica de contraste de fase do lodo de inóculo: presença de filamentos, bacilos, cocos e filamentos semelhantes à Mehtanosaeta sp....

Figura 5 - Valores médios dos dados de monitoramento do $\mathrm{pH}$ : (•) início e (०) final do ciclo; experimento utilizando nitrato como receptor de elétrons

Figura 6 - Valores médios dos dados de monitoramento de sulfato: (•) início e (०) final do ciclo; experimento utilizando nitrato como receptor de elétrons

Figura 7 - Valores médios dos dados de monitoramento de sulfeto: (•) início e (o) final do ciclo; ---- concentração teórica adicionada de sulfeto; experimento utilizando nitrato como receptor de elétrons

Figura 8 - Valores médios da variação de sulfato: ---- concentração teórica resultante de sulfato; experimento utilizando nitrato como receptor de elétrons.

Figura 9 - Valores médios dos dados de monitoramento de nitrato: (•) início e (०) final do ciclo; ---- concentração teórica adicionada de nitrato; experimento utilizando nitrato como receptor de elétrons

Figura 10 - Valores médios dos dados de monitoramento de nitrito: $(\bullet)$ início e (०) final do ciclo; experimento utilizando nitrato como receptor de elétrons

Figura 11 - Valores médios dos dados de monitoramento de nitrogênio amoniacal: $(\bullet)$ início e (०) final do ciclo; experimento utilizando nitrato como receptor de elétrons

Figura 12 - Valores médios dos dados de monitoramento do $\mathrm{pH}$ : (•) início e (o) final do ciclo; experimento utilizando nitrito como receptor de elétrons .....

Figura 13 - Valores médios dos dados de monitoramento de sulfato: $(\bullet)$ início e (०) final do ciclo; experimento utilizando nitrito como receptor de elétrons.....

Figura 14 - Valores médios da variação de sulfato: ---- concentração teórica resultante de sulfato; experimento utilizando nitrito como receptor de elétrons .....

Figura 15 - Valores médios dos dados de monitoramento de sulfeto: (•) início e (०) final do ciclo; --- concentração teórica adicionada de sulfeto; experimento utilizando nitrito como receptor de elétrons 
Figura 16 - Valores médios dos dados de monitoramento de nitrato: (•) início e (०) final do ciclo; experimento utilizando nitrito como receptor de elétrons

Figura 17 - Valores médios dos dados de monitoramento de nitrito: (•) início e (०) final do ciclo; ---- concentração teórica adicionada de nitrito;experimento utilizando nitrito como receptor de elétrons

Figura 18 - Valores médios dos dados de monitoramento de nitrogênio amoniacal: $(\bullet)$ início e (o) final do ciclo; experimento utilizando nitrito como receptor de elétrons

Figura 19 - Valores médios dos dados de monitoramento do pH: (•) início e (०) final do ciclo; experimento da segunda fase

Figura 20 - Valores médios dos dados de monitoramento de sulfeto: (•) início e (०) final do ciclo; --- concentração teórica adicionada de sulfeto; experimento da segunda fase

Figura 21 - Valores médios dos dados de monitoramento de sulfato: (•) início e (०) final do ciclo; experimento da segunda fase

Figura 22 - Valores médios da variação de sulfato: ---- concentração teórica resultante de sulfato; experimento da segunda fase.

Figura 23 - Valores médios dos dados de monitoramento de nitrato: (•) início e (०) final do ciclo; experimento da segunda fase

Figura 24 - Valores médios dos dados de monitoramento de nitrato: (•) início e (o) final do ciclo; ---- concentração teórica adicionada de nitrato; experimento da segunda fase

Figura 25 - Valores médios dos dados de monitoramento de nitrogênio amoniacal: (•) início e (o) final do ciclo; experimento da segunda fase

Figura 26 - Primeiro perfil temporal dos parâmetros durante um ciclo de 24 horas, com emprego de nitrato como receptor de elétrons, em RI1: $(\bullet) \mathrm{N}^{-\mathrm{NO}_{3}}{ }^{-} ;(\boldsymbol{\Delta})$

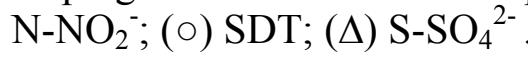

Figura 27 - Primeiro perfil temporal dos parâmetros durante um ciclo de 24 horas, com emprego de nitrato como receptor de elétrons, em RI2: (•) $\mathrm{N}^{-\mathrm{NO}_{3}}{ }^{-} ;(\boldsymbol{\Delta})$

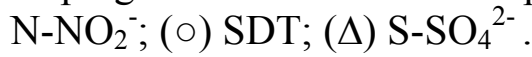

Figura 28 - Primeiro perfil temporal dos parâmetros durante um ciclo de 24 horas, com emprego de nitrato como receptor de elétrons, em RI3: $(\bullet) \mathrm{N}^{-\mathrm{NO}_{3}}{ }^{-} ;(\boldsymbol{\Delta})$

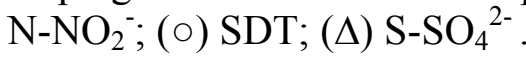

Figura 29 - Segundo perfil temporal dos parâmetros durante um ciclo de 24 horas, com emprego de nitrato como receptor de elétrons, em RI1: $(\bullet) \mathrm{N}^{-\mathrm{NO}_{3}}{ }^{-} ;(\boldsymbol{\Delta})$ $\mathrm{N}-\mathrm{NO}_{2}{ }^{-} ;(0) \mathrm{SDT} ;(\Delta) \mathrm{S}_{-} \mathrm{SO}_{4}{ }^{2-}$ 
Figura 30 - Segundo perfil temporal dos parâmetros durante um ciclo de 24 horas, com emprego de nitrato como receptor de elétrons, em RI2: (•) $\mathrm{N}^{-\mathrm{NO}_{3}}{ }^{-} ;(\boldsymbol{\Delta})$ $\mathrm{N}-\mathrm{NO}_{2}^{-} ;(0) \mathrm{SDT} ;(\Delta) \mathrm{S}_{-} \mathrm{SO}_{4}{ }^{2-}$

Figura 31 - Segundo perfil temporal dos parâmetros durante um ciclo de 24 horas, com emprego de nitrato como receptor de elétrons, em RI3: (•) $\mathrm{N}_{-\mathrm{NO}_{3}}^{-} ;(\boldsymbol{\Delta})$

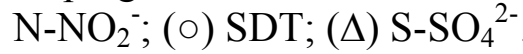

Figura 32 - Perfil temporal dos parâmetros durante um ciclo de 24 horas, com emprego de nitrito como receptor de elétrons, em RI1: (•) $\mathrm{N}_{-\mathrm{NO}_{3}}^{-} ;(\boldsymbol{\Delta})$ $\mathrm{N}-\mathrm{NO}_{2}^{-} ;(0) \mathrm{SDT} ;(\Delta) \mathrm{S}_{-} \mathrm{SO}_{4}{ }^{2-}$

Figura 33 - Perfil temporal dos parâmetros durante um ciclo de 24 horas, com emprego de nitrito como receptor de elétrons, em RI2: (•) $\mathrm{N}^{-N_{3}}{ }_{3}^{-} ;(\boldsymbol{\Delta})$ $\mathrm{N}-\mathrm{NO}_{2}^{-} ;(0) \mathrm{SDT} ;(\Delta) \mathrm{S}_{-} \mathrm{SO}_{4}{ }^{2-}$

Figura 34 - Perfil temporal dos parâmetros durante um ciclo de 24 horas, com emprego de nitrito como receptor de elétrons, em RI3: $(\bullet) \mathrm{N}_{-}-\mathrm{NO}_{3}{ }^{-} ;(\boldsymbol{\Delta})$

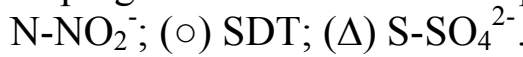

Figura 35 - Primeiro perfil temporal dos parâmetros durante um ciclo de 24 horas, com emprego de nitrato como receptor de elétrons, em RI1 (segunda fase): (•) $\mathrm{N}-\mathrm{NO}_{3}^{-} ;(\boldsymbol{\Delta}) \mathrm{N}^{-} \mathrm{NO}_{2}^{-} ;(\mathrm{O}) \mathrm{SDT} ;(\Delta) \mathrm{S}^{-} \mathrm{SO}_{4}{ }^{2-}$

Figura 36 - Primeiro perfil temporal dos parâmetros durante um ciclo de 24 horas, com emprego de nitrato como receptor de elétrons, em RI2 (segunda fase): (•) $\mathrm{N}-\mathrm{NO}_{3}^{-} ;(\boldsymbol{\Delta}) \mathrm{N}_{-} \mathrm{NO}_{2}^{-} ;(\circ) \mathrm{SDT} ;(\Delta) \mathrm{S}_{-} \mathrm{SO}_{4}{ }^{2-}$

Figura 37 - Primeiro perfil temporal dos parâmetros durante um ciclo de 24 horas, com emprego de nitrato como receptor de elétrons, em RI3 (segunda fase): $(\bullet)$

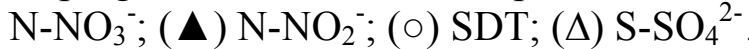

Figura 38 - Primeiro perfil temporal da DQO total durante um ciclo de 24 horas, com emprego de nitrato como receptor de elétrons: (०) RI1; ( $\square)$ RI2; ( $\Delta$ ) RI3

Figura 39 - Segundo perfil temporal dos parâmetros durante um ciclo de 24 horas, com emprego de nitrato como receptor de elétrons, em RI1 (segunda fase): (•) $\mathrm{N}-\mathrm{NO}_{3}{ }^{-} ;(\boldsymbol{\Delta}) \mathrm{N}_{-} \mathrm{NO}_{2}{ }^{-} ;(\mathrm{O}) \mathrm{SDT} ;(\Delta) \mathrm{S}^{-\mathrm{SO}_{4}}{ }^{2-}$

Figura 40 - Segundo perfil temporal dos parâmetros durante um ciclo de 24 horas, com emprego de nitrato como receptor de elétrons, em RI2 (segunda fase): (•) $\mathrm{N}-\mathrm{NO}_{3}^{-} ;(\boldsymbol{\Delta}) \mathrm{N}_{-} \mathrm{NO}_{2}^{-} ;(\circ) \mathrm{SDT} ;(\Delta) \mathrm{S}^{-} \mathrm{SO}_{4}{ }^{2-}$

Figura 41 - Segundo perfil temporal dos parâmetros durante um ciclo de 24 horas, com emprego de nitrato como receptor de elétrons, em RI3 (segunda fase): (•) $\mathrm{N}-\mathrm{NO}_{3}^{-} ;(\boldsymbol{\Delta}) \mathrm{N}_{-} \mathrm{NO}_{2}^{-} ;(\mathrm{O}) \mathrm{SDT} ;(\Delta) \mathrm{S}_{-} \mathrm{SO}_{4}{ }^{2-}$

Figura 42 - Segundo perfil temporal da DQO total durante um ciclo de 24 horas, com emprego de nitrato como receptor de elétrons: (०) RI1; ( $\square)$ RI2; $(\Delta)$ RI3

Figura 43 - Ajustes de modelos cinéticos considerando reação de primeira ordem para remoção de nitrato (primeiro perfil): (o) RI1; ( $\square)$ RI2; ( $\Delta$ ) RI3 
Figura 44 - Velocidades específicas de remoção de nitrato (primeiro perfil): (O) RI1; () RI2; ( $\Delta)$ RI3

Figura 45 - Ajustes de modelos cinéticos considerando reação de ordem zero para

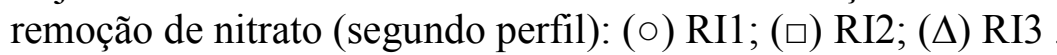

Figura 46 - Ajustes de modelos cinéticos considerando reação de primeira ordem para remoção de nitrito: (०) RI1; ( $\square) \mathrm{RI} 2 ;(\Delta) \mathrm{RI} 3$

Figura 47 - Velocidades específicas de remoção de nitrito: (०) RI1; (口) RI2; ( $\Delta$ ) RI3 79

Figura 48 - Ajustes de modelos cinéticos considerando reação de primeira ordem para remoção de nitrato (primeiro perfil da segunda fase): (०) RI1; ( $\square)$ RI2; ( $\Delta$ ) $\mathrm{RI} 3$.

Figura 49 - Ajustes de modelos cinéticos considerando reação de primeira ordem para remoção de nitrato (segundo perfil da segunda fase): (०) RI1; ( $)$ RI2; $(\Delta)$ RI3.....

Figura 50 - Velocidades específicas de remoção de nitrato (primeiro perfil da segunda fase): ( ०) RI1; ( $\square)$ RI2; ( $\Delta$ ) RI3 .

Figura 51 - Velocidades específicas de remoção de nitrato (segundo perfil da segunda fase): (o) RI1; ( $\square) \mathrm{RI}$; ( $\Delta$ ) RI3

Figura 52 - Morfologias observadas sob microscopia óptica de contraste de fase no período inicial dos experimentos. (a) Filamentos, cocos, aglomerado de bacilos e material inerte, (b) bacilos dispersos, (c) cocos, (d) morfologia semelhante a Methanosarcina.

Figura 53 - Morfologias observadas sob microscopia óptica de contraste de fase após 30 dias de operação da primeira fase. (a) Aglomerado de bacilos próximos à formas semelhantes à enxofre elementar, (b) Aglomerado de bacilos próximos à formas semelhantes à enxofre elementar e alguns filamentos.

Figura 54 - Morfologias observadas sob microscopia óptica de contraste de fase na condição N/S equivalente a 1,6. (a) Bacilos dispersos e filamentos (b) Formas semelhantes à enxofre elementar

Figura 55 - Morfologias observadas sob microscopia óptica de contraste de fase na condição $\mathrm{N} / \mathrm{S}$ equivalente a 0,8 . (a) Bacilos e formas semelhantes à enxofre elementar (b) Formas semelhantes à enxofre elementar.

Figura 56 - Morfologias observadas sob microscopia óptica de contraste de fase na condição em que foi aplicado nitrito como receptor de elétrons, após o aquecimento de $100^{\circ} \mathrm{C}$. (a) e (b) bacilos com morfologia descaracterizada.

Figura 57 - Morfologias observadas sob microscopia óptica de contraste de fase referente aos experimentos realizados na segunda fase. (a) aglomerado de bacilos, (b) bacilos dispersos e espiroquetas, (c) bacilos e formas semelhantes a enxofre elementar, (d) filamento e espiroquetas..... 


\section{LISTA DE TABELAS}

Tabela 1 - Composição da água residuária sintética nitrificada.

Tabela 2 - Composição dos micronutrientes presentes na água residuária.

Tabela 3 - Caracterização do efluente real de reator anaeróbio tratando água residuária de abatedouro de aves utilizado.

Tabela 4 - Concentrações teóricas do doador e dos receptores de elétrons correspondentes às relações $\mathrm{N} / \mathrm{S}$ aplicadas nas duas fases na pesquisa.

Tabela 5 - Parâmetros e metodologia de análise

Tabela 6 - Cronograma da alimentação e das análises de monitoramento realizados semanalmente.

Tabela 7 - Concentrações teóricas das soluções de sulfeto e de nitrato aplicadas aos ensaios abióticos, com as respectivas relações $\mathrm{N} / \mathrm{S}$, em ambas as fases.

Tabela 8 - Valores médios do monitoramento da DQO total.

Tabela 9 - Parâmetros adimensionais para avaliação da magnitude dos efeitos de transferência de massa, para os três reatores estudados, relativos ao primeiro perfil temporal empregando nitrato como receptor de elétrons.

Tabela 10 - Parâmetros adimensionais para avaliação da magnitude dos efeitos de transferência de massa, para os três reatores estudados, relativos ao segundo perfil temporal empregando nitrato como receptor de elétrons.

Tabela 11 - Parâmetros adimensionais para avaliação da magnitude dos efeitos de transferência de massa, para os três reatores estudados, relativos ao perfil temporal empregando nitrito como receptor de elétrons.

Tabela 12 - Velocidades específicas de remoção de nitrato referentes aos experimentos realizados na segunda fase.

Tabela 13 - Parâmetros adimensionais para avaliação da magnitude dos efeitos de transferência de massa, para os três reatores estudados, relativos ao perfil temporal empregando nitrito como receptor de elétrons.

Tabela 14 - Efeito das atividades químicas na desnitrificação autotrófica avaliada em reatores em batelada durante um ciclo de 24 horas.

Tabela 15 - Valores médios dos parâmetros monitorados nas duas fases do trabalho, para cada receptor de elétrons utilizado, medidos no início e ao final de 24 horas. 
Tabela 16 - Valores médios dos parâmetros relativos à modelagem cinética, obtidos para os três reatores, contemplando as duas fases do trabalho e os dois receptores de elétrons utilizados. 


\section{LISTA DE ABREVIATURAS E SIGLAS}

$B i \quad$ Número de Biot

$C_{N^{\prime}} \quad$ Concentração de nitrogênio por unidade de massa de SSV .[L $]^{-3}$

$C_{N} \quad$ Concentração de nitrogênio [M].[L $]^{-3}$

$C_{N i} \quad$ Concentração de nitrogênio na interface líquido sólido [M].[L] $]^{-3}$

$C_{N L} \quad$ Concentração de nitrogênio na fase líquida [M].[L] $]^{-3}$

$D_{e} \quad$ Difusividade efetiva do substrato $[\mathrm{L}]^{2} \cdot[\mathrm{T}]^{-1}$

$D_{L} \quad$ Difusividade do substrato na fase líquida $[\mathrm{L}]^{2} \cdot[\mathrm{T}]^{-1}$

$d_{p} \quad$ Diâmetro da esfera equivalente [L]

DQO Demanda química de oxigênio

$\mathrm{HS}^{-} \quad$ Sulfeto na forma iônica

$\mathrm{H}_{2} \mathrm{~S} \quad$ Sulfeto de hidrogênio

$J_{D} \quad$ Fator de Colburn

$k_{0} \quad$ Constante cinética específica de ordem zero [T] $]^{-1}$

$k_{1} \quad$ Constante cinética de primeira ordem $[\mathrm{T}]^{-1}$

$k_{s} \quad$ Coeficiente de transferência de massa líquido-sólido $[\mathrm{L}]^{3}$.[T $]^{-1}$

$\mathrm{N}-\mathrm{NH}_{4}^{+} \quad$ Nitrogênio na forma amoniacal

$\mathrm{N}_{-} \mathrm{NO}_{3}{ }^{-} \quad$ Nitrogênio na forma de nitrato

$\mathrm{N}_{-} \mathrm{NO}_{2}{ }^{-} \quad$ Nitrogênio na forma de nitrito

RDNA Redução dissimilativa de nitrato a amônia

$r_{N} \quad$ Velocidade de reação (consumo de nitrogênio) $[\mathrm{M}] .[\mathrm{L}]^{-3}[\mathrm{~T}]^{-1}$

$r_{N^{\prime}} \quad$ Velocidade específica de consumo de nitrogênio $[\mathrm{T}]^{-1}$

$r_{N_{o b s}} \quad$ Velocidade específica de consumo de nitrogênio observada $[\mathrm{T}]^{-1}$

$R_{e p}{ }^{*} \quad$ Número de Reynolds de partícula modificado

$R_{p} \quad$ Raio da biopartícula [L]

RI1 Reator em batelada com biomassa imobilizada 1

RI2 Reator em batelada com biomassa imobilizada 2

RI3 Reator em batelada com biomassa imobilizada 3

SDF Sólidos dissolvidos fixos [M] 
SDT Sulfeto dissolvido total [M]

SDV Sólidos dissolvidos voláteis [M]

SSF Sólidos suspensos fixos [M]

SSV Sólidos suspensos voláteis [M]

STF Sólidos totais fixos [M]

STV Sólidos totais voláteis [M]

$\mathrm{S}^{2-} \quad$ Sulfeto na forma iônica

$\mathrm{S}-\mathrm{SO}_{4}{ }^{2-} \quad$ Enxofre na forma de sulfato

Sc Número de Schimidt

Sh Número de Sherwood

$\alpha \quad$ Coeficiente de absorção

$\mu_{\mathrm{L}} \quad$ Viscosidade do líquido $[\mathrm{L}]^{2} \cdot[\mathrm{T}]^{-1}$

$\mu_{\mathrm{m}} \quad$ Micrômetro [L]

mM Milimolar

$\mathrm{v}_{\mathrm{S}} \quad$ Velocidade superficial de líquido considerando a área da seção líquida do reator

$\varepsilon \quad$ Porosidade do leito

$\phi_{\text {obs }} \quad$ Módulo de Thiele observado

$\eta \quad$ Fator de efetividade 



\section{SUMÁRIO}

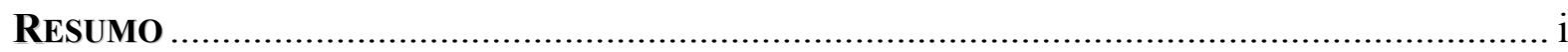

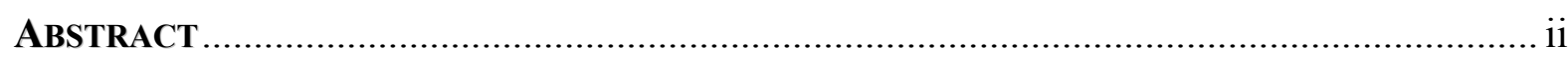

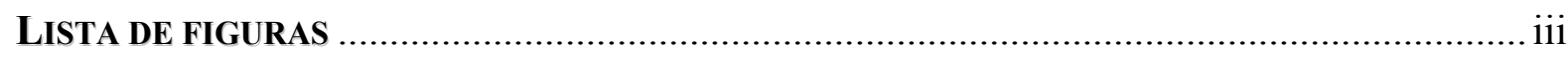

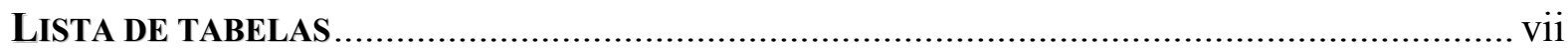

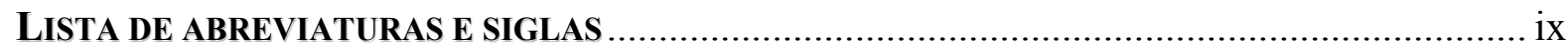

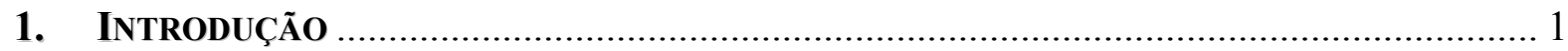

2. OBJETIVOS

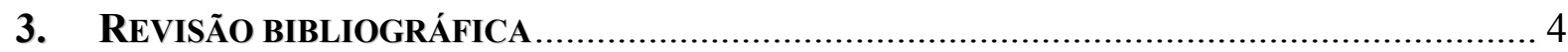

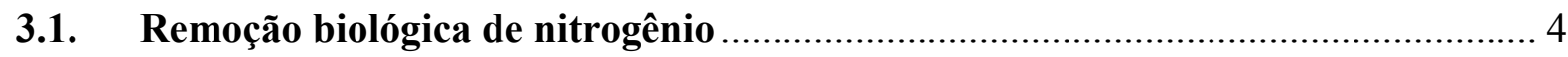

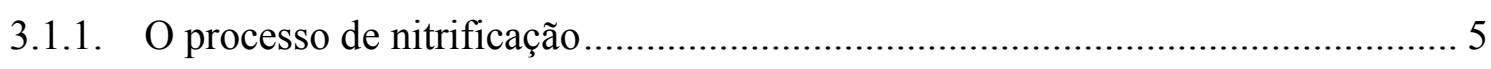

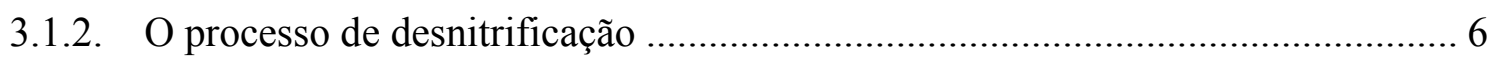

3.1.3. Nitrificação e desnitrificação simultâneas ......................................................... 7

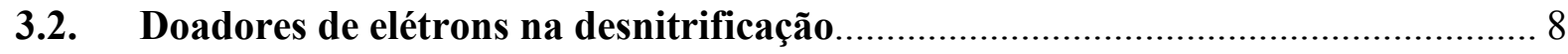

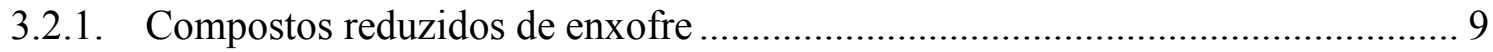

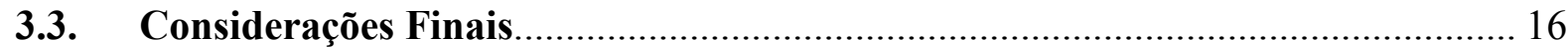

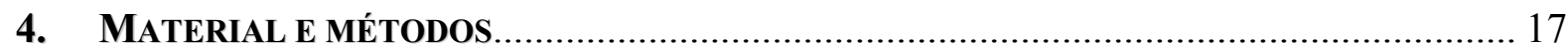

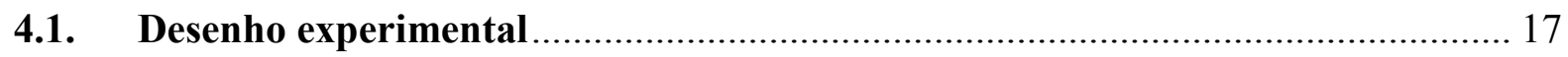

4.2. Descrição dos reatores desnitrificantes operados em batelada........................... 19

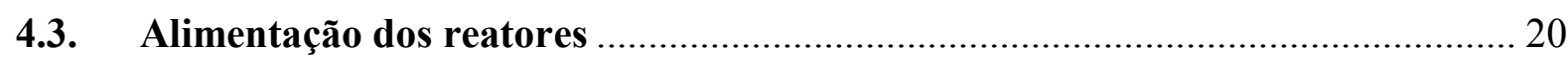

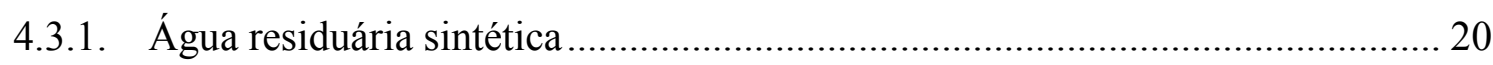

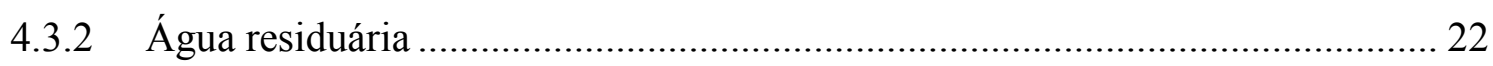

4.3.3. Sulfeto de sódio fornecido como doador de elétrons ......................................... 23

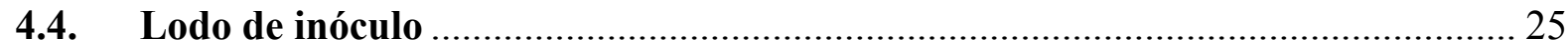

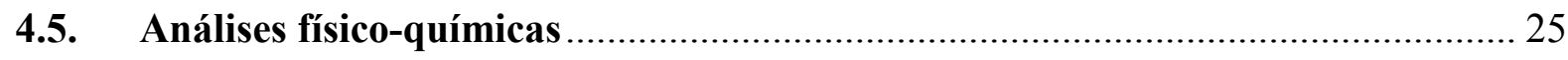

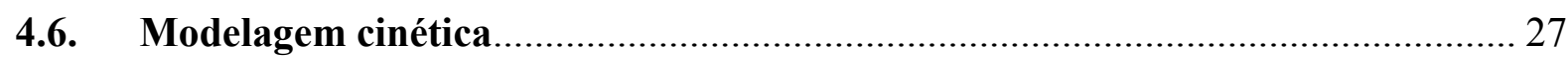

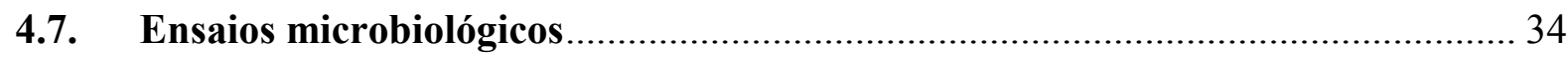

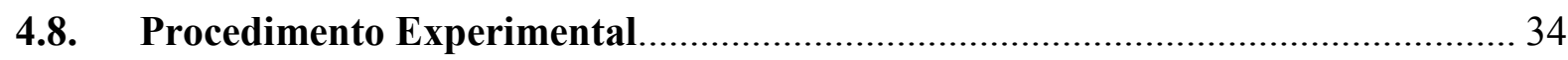

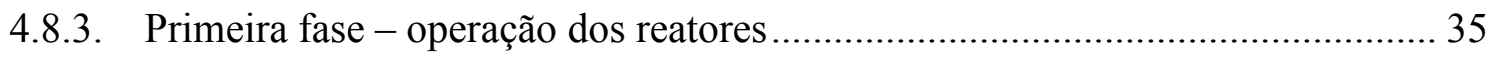




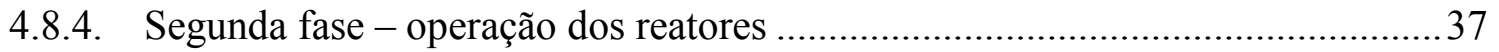

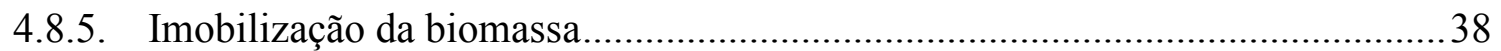

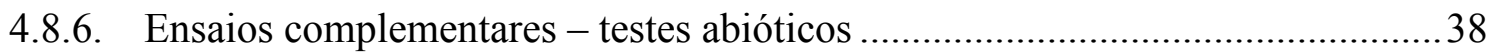

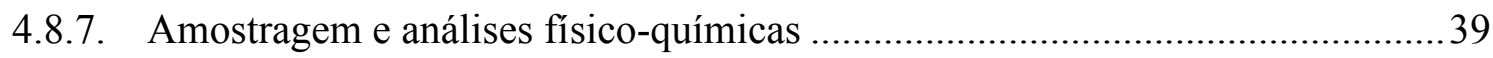

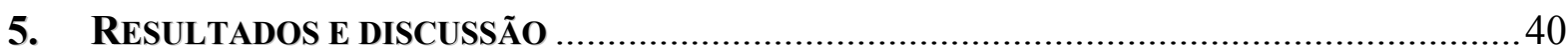

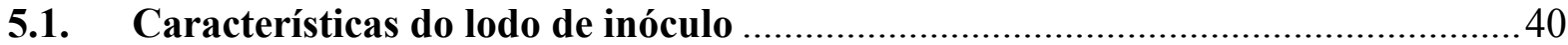

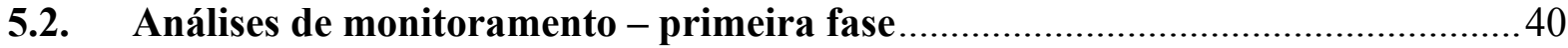

5.2.1. Nitrato como receptor de elétrons ............................................................... 41

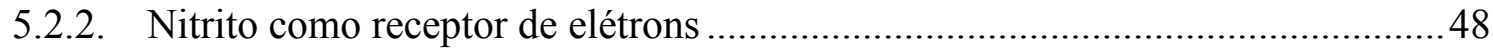

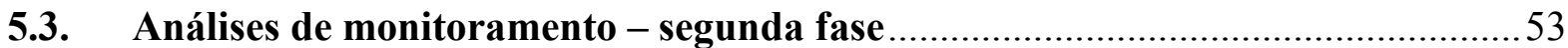

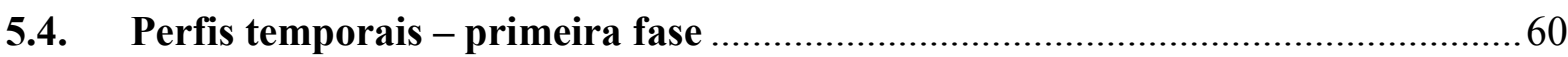

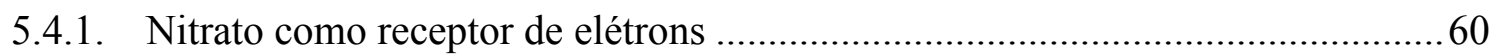

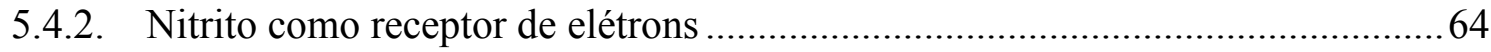

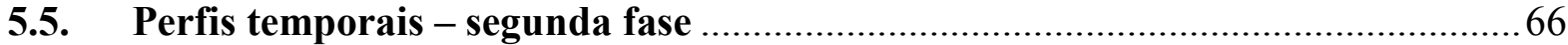

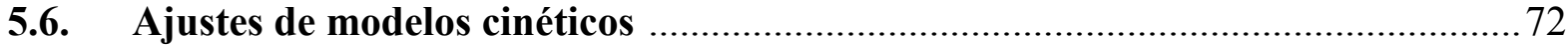

5.6.1. Parâmetros utilizados na análise dos fenômenos de transferência de massa...... 72

5.6.2. Primeira fase - nitrato como receptor de elétrons .............................................. 73

5.6.3. Primeira fase - nitrito como receptor de elétrons................................................ 78

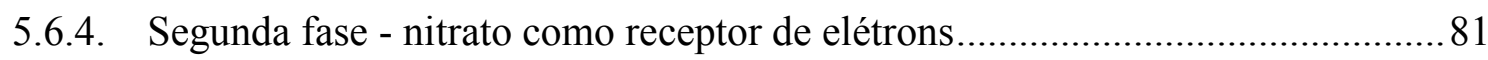

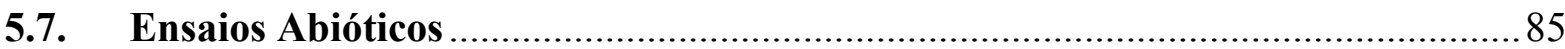

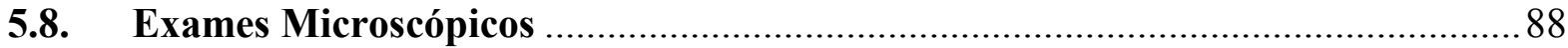

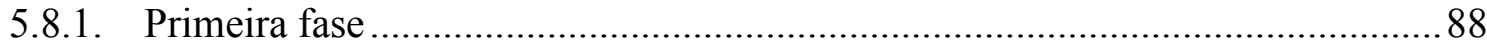

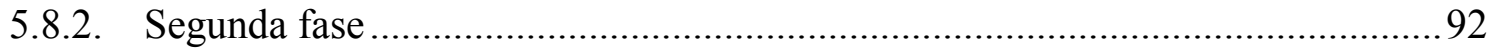

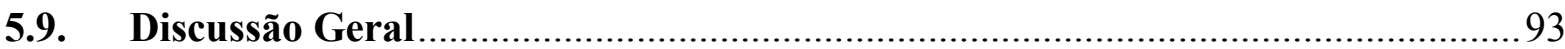

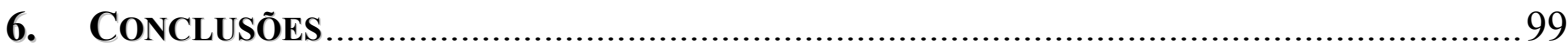

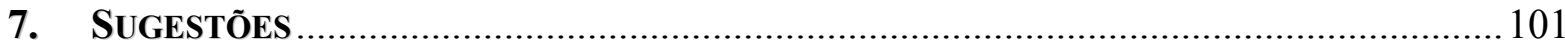

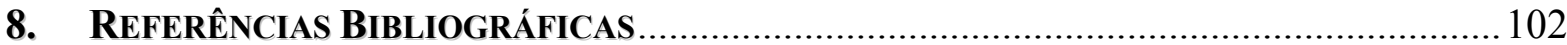





\section{INTRODUÇÃO}

$\mathrm{O}$ reconhecimento da interdependência entre ambiente e crescimento industrial e populacional fez com que houvesse uma maior preocupação e conscientização em relação aos problemas ambientais advindos de tal relação. Desse modo, as exigências da legislação ambiental têm sido intensificadas com relação ao lançamento de efluentes em corpos d'água receptores. Conseqüentemente, estão sendo utilizadas as mais diversas alternativas para o tratamento de águas residuárias, com a finalidade de melhor proteger os corpos hídricos.

Com relação ao tratamento biológico de esgotos sanitários no Brasil, nos últimos anos, tem-se notado a crescente utilização de reatores anaeróbios como primeira unidade de tratamento para remoção de matéria orgânica, tendo em vista as vantagens econômicas e operacionais destes sobre os reatores aeróbios. Entretanto, o tratamento anaeróbio não promove a remoção eficiente de nutrientes (N e P). Sendo assim, há a necessidade do póstratamento do efluente de reator anaeróbio, de modo que este apresente a qualidade adequada para ser descartado, de acordo com as normas vigentes na legislação brasileira.

Convencionalmente, a remoção biológica de nitrogênio envolve duas etapas principais: a nitrificação autotrófica seguida pela desnitrificação heterotrófica, as quais resultam na formação de nitrogênio gasoso como produto final. O processo global requer a disponibilidade de alcalinidade e oxigênio no meio para a nitrificação, e de uma fonte orgânica de elétrons para a desnitrificação. Neste último processo, os microrganismos utilizam a matéria orgânica originada de fontes endógenas ou exógenas como fonte de energia e de carbono. Entretanto, a utilização de reator anaeróbio como primeira unidade de tratamento, a qual vem crescendo no Brasil, implica na remoção da fração de matéria orgânica rapidamente biodegradável que poderia ser utilizada como fonte endógena para desnitrificação heterotrófica. Desse modo, se faz necessária a adição de fontes externas de 
carbono para a remoção de nitrogênio, resultando em um considerável encarecimento operacional desse sistema.

O aumento nos custos operacionais do tratamento justifica a realização de diversas pesquisas direcionadas à minimização dos custos relacionados à desnitrificação por meio da utilização de fontes alternativas de doadores de elétrons. Entre tais pesquisas destaca-se a viabilidade da aplicação da desnitrificação autotrófica utilizando fontes endógenas, uma vez que, segundo Foresti et al. (2006), a biodigestão anaeróbia gera subprodutos que podem ser recuperados e reutilizados, como o biogás, o qual apresenta grande potencial de uso, seja como alternativa energética renovável, seja como produto para outros processos.

Neste trabalho foi avaliada a viabilidade da desnitrificação autotrófica utilizando sulfeto como doador de elétrons, aplicada a efluentes nitrificados e parcialmente nitrificados de reatores anaeróbios tratando esgoto sanitário e água residuária de abatedouro de aves, o qual apresenta composição semelhante ao esgoto, porém concentrado.

É importante salientar que para melhor descrever e compreender os processos físicos e bioquímicos envolvidos na desnitrificação autotrófica utilizando compostos de enxofre se faz necessária a investigação de modelos cinéticos para tais processos. Há relatos na literatura sobre a cinética da desnitrificação autotrófica com a utilização de enxofre elementar (Batchelor et al., 1978; Koenig e Liu, 2001; Kim et al., 2004). Entretanto, existem poucas informações a respeito da cinética deste processo utilizando sulfetos como fonte de elétrons, fato que ressalta a importância da realização de pesquisas nesta área. 


\section{OBJETIVOS}

O objetivo geral da pesquisa foi avaliar a viabilidade da desnitrificação autotrófica, utilizando sulfeto como doador de elétrons, aplicada a efluentes de reatores anaeróbios tratando esgoto sanitário, com vistas a aprofundar a investigação de aspectos fundamentais deste processo.

Os objetivos específicos foram:

- Avaliar a viabilidade técnica da aplicação da desnitrificação autotrófica no tratamento de efluentes de reatores anaeróbios nitrificados em reatores operados em bateladas utilizando-se sulfeto como doador de elétrons para a desnitrificação;

- Verificar as relações N/S que proporcionem melhor remoção de nitrogênio de efluentes de reatores anaeróbios nitrificados, com a aplicação da desnitrificação autotrófica empregando sulfeto;

- Avaliar a viabilidade técnica da aplicação da desnitrificação autotrófica no tratamento de efluentes de reatores anaeróbios em reatores operados em bateladas com uma mistura de efluentes nitrificados e não nitrificados;

- Determinar os parâmetros cinéticos da desnitrificação autotrófica;

- Avaliar a diversidade microbiana presente nos reatores desnitrificantes por meio de microscopia de contraste de fase. 


\section{REVISÃO BIBLIOGRÁFICA}

Neste item é apresentado primeiramente o processo biológico convencional de remoção de nitrogênio, sendo abordados os aspectos físico-químicos e microbiológicos referentes à nitrificação autotrófica e desnitrificação heterotrófica. Seqüencialmente, é discutida a busca por novos processos de remoção biológica de nitrogênio, sendo ressaltada a possibilidade de integrar a remoção de compostos de enxofre a estes sistemas.

\subsection{REMOÇÃO BIOLÓGICA DE NITROGÊNIO}

O descarte, nos corpos receptores, de nutrientes provenientes de esgotos sanitários e águas residuárias industriais, como o nitrogênio e o fósforo, é o principal responsável pela eutrofização dos corpos hídricos, já que propicia o crescimento de plantas aquáticas. Além disso, o nitrogênio amoniacal é facilmente oxidado por organismos nitrificantes que consomem o oxigênio dissolvido, podendo tornar a vida aquática aeróbia inviável. Dessa forma, a remoção de nutrientes é de extrema importância no tratamento de efluentes, particularmente com relação aos compostos nitrogenados, cujos padrões de lançamento exigidos pela legislação têm se tornado cada vez mais restritivos.

Com intuito de preservar a qualidade dos corpos receptores e atender aos requisitos da legislação vigente, diversos processos de remoção de nitrogênio vêm sendo estudados (Ahn, 2006; Khin e Annachhatre, 2004; Villaverde, 2004; Vestraete e Philip, 1998), no sentido de se integrar, com sucesso, a etapa de remoção biológica de nitrogênio a sistemas sustentáveis.

O método mais comum de remoção consiste em promover a nitrificação, em ambiente aeróbio, e subseqüentemente a desnitrificação em ambiente anóxico. Porém, Lee et al. (2001) ressaltam que estes processos podem ocorrer simultaneamente quando o reator é submetido a reduzidas concentrações de oxigênio dissolvido. 


\subsubsection{O processo de nitrificação}

A nitrificação convencional é um processo autotrófico que envolve a conversão aeróbia de $\mathrm{N}-\mathrm{NH}_{4}{ }^{+}$a N-NO${ }_{2}^{-}$ou N-NO${ }_{3}^{-}$, tendo $\mathrm{O}_{2}$ como receptor de elétrons. A fonte de carbono inorgânico para crescimento da biomassa é o $\mathrm{CO}_{2}$ (Metcalf \& Eddy, 2003).

De acordo com Henze et al. (1997), a etapa limitante deste processo é a oxidação do $\mathrm{N}$-amoniacal devido ao fato de sua velocidade ser mais lenta em relação à oxidação do nitrito. Os autores ainda afirmam que a temperatura, o pH, a concentração de oxigênio dissolvido, a concentração e composição do substrato são fatores ambientais importantes que influenciam o processo de nitrificação.

Van Haandel e Marais (1999) descrevem as etapas deste processo conforme a equação (1) e a equação (2). Pode-se observar que, para cada mol de $\mathrm{N}^{-\mathrm{NO}_{3}}{ }^{-}$(14 g) formado há produção de 2 mols de $\mathrm{H}^{+}$(acidez mineral), o que é equivalente ao consumo de $100 \mathrm{~g}$ de $\mathrm{CaCO}_{3}$, ou seja, ocorre a redução da alcalinidade. Também é possível observar as altas demandas de oxigênio requeridas para oxidação de $\mathrm{N}$-amoniacal.

$$
\begin{gathered}
\mathrm{NH}_{4}^{+}+3 / 2 \mathrm{O}_{2} \rightarrow \mathrm{NO}_{2}^{-}+\mathrm{H}_{2} \mathrm{O}+2 \mathrm{H}^{+} \\
\mathrm{NO}_{2}^{-}+1 / 2 \mathrm{O}_{2} \rightarrow \mathrm{NO}_{3}^{-}
\end{gathered}
$$

Os estágios envolvidos na nitrificação ocorrem devido à ação de gêneros distintos de bactérias, os quais utilizam amônia ou nitrito como fonte de energia e dióxido de carbono como fonte inorgânica de carbono, enquanto o oxigênio molecular é o receptor final de elétrons. Na nitritação, conversão de nitrogênio amoniacal a nitrito, o gênero mais comumente envolvido é Nitrosomonas, sendo que, segundo Ahn (2006), Nitrosococcus, Nitrosopira, Nitrosovibrio e Nitrosolobus também são capazes de oxidar amônia a nitrito. Na nitratação, conversão de nitrito a nitrato, há destaque para o gênero Nitrobacter, sendo conhecidos 
também Nitrospira, Nitrospina, Nitrococcus e Nitrocystis (Schmidt et al., 2003; Metcalf e Eddy, 2003).

\subsubsection{O processo de desnitrificação}

A desnitrificação é a conversão biológica do nitrogênio, na forma de nitrato e nitrito, a formas mais reduzidas, como $\mathrm{NO}, \mathrm{N}_{2} \mathrm{O}$ e $\mathrm{N}_{2}$ (Ros, 1995). A utilização de compostos de carbono como doadores de elétrons neste processo é a forma mais conhecida de remoção de nitrogênio.

As reações de redução de nitrato envolvem as seguintes etapas: redução de nitrato a nitrito, a óxido nítrico, a óxido nitroso e finalmente a nitrogênio gasoso, conforme representado a seguir (Metcalf e Eddy, 2003):

$$
\mathrm{NO}_{3}^{-} \rightarrow \mathrm{NO}_{2}^{-} \rightarrow \mathrm{NO} \rightarrow \mathrm{N}_{2} \mathrm{O} \rightarrow \mathrm{N}_{2}
$$

Os três últimos produtos são liberados na forma gasosa, mas apenas a redução a $\mathrm{N}_{2}$ é capaz de evitar danos ambientais como a destruição da camada de ozônio e intensificação do efeito estufa.

Para que o processo de desnitrificação se desenvolva, algumas condições ambientais são necessárias, como a baixa concentração ou ausência de oxigênio dissolvido e substâncias tóxicas, presença de nitrato ou nitrito como receptores de elétrons, e valores adequados de temperatura e pH do meio (van Haandel e Marais, 1999; Garbossa, 2006).

Com relação à alcalinidade, van Haandel et al. (1999) afirmam que o processo de desnitrificação recupera a metade do que foi consumido na nitrificação, reduzindo ou eliminando a necessidade de adição de cal para corrigir o pH. Segundo os mesmos autores, há produção de $50 \mathrm{~g}$ de $\mathrm{CaCO}_{3}$ por mol de $\mathrm{N}(14 \mathrm{~g})$. 

ao tratamento de esgoto sanitário

As bactérias envolvidas na desnitrificação heterotrófica utilizam nitrito ou nitrato como receptores de elétrons e matéria orgânica como fonte de carbono e energia. O gênero Pseudomonas é o mais comum entre as desnitrificantes, havendo ainda Alcaligenes, Achromobacter, Acinetobacter, Agrobacterium, Arthrobacter, Bacillus, Chromobacterium, Corynebacterium, Flavobacterium, Hypomicrobium, Moraxella, Neissria, Paracoccus, Propionibacterium, Rhizobium, Rhodopseudomonas, Spirillum e Vibrio (Ahn, 2006; Metcalf e Eddy, 2003).

\subsubsection{Nitrificação e desnitrificação simultâneas}

Este processo consiste na ocorrência da nitrificação e desnitrificação em um mesmo reator, no qual o N-amoniacal é removido em uma única etapa. Segundo Iamamoto (2006), este processo requer um substrato lentamente biodegradável devido à lenta oxidação de Namoniacal, de modo que o potencial redutor desse substrato esteja disponível para a desnitrificação ao invés de ser rapidamente oxidado a $\mathrm{CO}_{2}$ nos períodos aerados.

Alguns estudos mostram que o processo simultâneo aumenta as vantagens econômicas, devido à diminuição do número ou do tamanho dos reatores, já que os processos de nitrificação e de desnitrificação ocorrem no mesmo reator sob condições idênticas de operação (Lee et al., 2001). Além disso, o referido processo é efetivo em manter o pH neutro no reator, sem adição de fonte externa de ácido/base, considerando que a faixa ótima para as bactérias nitrificantes está entre 7,6 - 8,6 enquanto que para as desnitrificantes está entre 7,08,0 (Iamamoto, 2006).

Em uma pesquisa realizada por Pochana e Keller (1999), foram avaliados os fatores que influenciam o processo simultâneo de nitrificação e desnitrificação como: fonte de carbono, concentração de oxigênio dissolvido e tamanho do floco. Foram utilizados reatores operados em bateladas seqüenciais, com aeração intermitente e sob agitação, que operaram 
em condições variáveis de temperatura, de $\mathrm{pH}$ e de concentração de oxigênio dissolvido. A adição de uma fonte de carbono de fácil degradação resultou em aumento significativo da velocidade de desnitrificação. Foi observada que com o aumento da concentração de oxigênio dissolvido, a taxa de nitrificação foi aumentada, havendo maior produção de nitrito e nitrato, o que causou o aumento concomitante na taxa de desnitrificação. Com relação ao tamanho dos flocos, sua diminuição de $80 \mu \mathrm{m}$ para $40 \mu \mathrm{m}$ provocou um decréscimo na eficiência do processo global, de $52 \%$ para $21 \%$. Assim, os autores concluíram que a limitação da difusão de oxigênio nos flocos permitiu a ocorrência simultânea da nitrificação e desnitrificação, o que gerou condições anóxicas no centro dos flocos.

\subsection{DOADORES DE ELÉTRONS NA DESNITRIFICAÇÃO}

A baixa concentração de matéria orgânica presente no efluente de sistemas de tratamento secundário faz com seja necessária a adição de uma fonte de doador de elétrons para que a desnitrificação se efetive. Com a finalidade de se obter maior compreensão de tal processo, juntamente com a minimização dos custos e a otimização da eficiência do mesmo, pesquisas acerca da influência de diferentes doadores de elétrons e sua relação com nitrogênio vêm sendo realizadas (Manconi et al., 2007; Kalyuzhnyi et al., 2006; Moon et al., 2004; Oh et al., 2002; Kimura et al., 2001; Pochana e Keller, 1999; Her e Huang, 1995).

Vale ressaltar que a desnitrificação utilizando doadores inorgânicos se procede na ausência de fonte externa de carbono, ao contrário da desnitrificação heterotrófica convencionalmente aplicada, ao mesmo tempo em que produz baixas quantidades de biomassa (Kimura et al., 2002). Além disso, a aplicação da desnitrificação autotrófica em efluentes de reatores anaeróbios é especialmente vantajosa em função da possibilidade de 

ao tratamento de esgoto sanitário

serem utilizadas fontes endógenas de doadores de elétrons. Assim, pode-se considerar esta alternativa eficiente e de baixo custo.

Inserida neste contexto, a utilização de compostos presentes no biogás ou solúveis no próprio efluente como doadores de elétrons se mostra como uma alternativa interessante, em particular os compostos de enxofre.

\subsubsection{Compostos reduzidos de enxofre}

A produção de sulfeto é um dos maiores problemas associados ao tratamento anaeróbio de efluentes contendo sulfato. Este apresenta odor desagradável e causa grande demanda de oxigênio no efluente, além de causar a corrosão em tubulações de esgoto feitas de aço e de concreto (Speece, 1996). A exposição de sulfeto, na forma gasosa, a seres humanos pode causar danos à saúde ou até mesmo ser fatal. O sulfeto gerado no tratamento anaeróbio é distribuído entre $\mathrm{S}^{2-}, \mathrm{HS}^{-}, \mathrm{H}_{2} \mathrm{~S}$ em solução e $\mathrm{H}_{2} \mathrm{~S}$ no biogás, além de sulfetos metálicos insolúveis, de acordo com o equilíbrio físico-químico. Sulfeto em solução é um ácido fraco, o qual se encontra em equilíbrio segundo a equação (3):

$$
H_{2} S_{(a q)} \leftrightarrow H S_{(a q)}^{-}+H^{+} \leftrightarrow S_{(a q)}^{2-}
$$

A distribuição das formas de sulfeto é função do $\mathrm{pH}$ da solução, conforme apresentado na Figura 1. Em pH neutro, o equilíbrio químico entre $\mathrm{H}_{2} \mathrm{~S}$ e $\mathrm{HS}^{-}$é o mais importante, sendo que pequenas variações de $\mathrm{pH}$ na faixa de 6 a 8 afetam significativamente a concentração de $\mathrm{H}_{2} \mathrm{~S}$. O equilíbrio entre $\mathrm{H}_{2} \mathrm{~S}$ na fase líquida e na fase gasosa é regido pela Lei de Henry, segundo a equação (4).

$$
H_{2} S_{(a q)}=\alpha \cdot H_{2} S_{(\text {gas })}
$$


Segundo Wilhelm et al. (1977), o coeficiente de absorção $\alpha$ do $\mathrm{H}_{2} \mathrm{~S}$ está em torno de 1,99 a $30^{\circ} \mathrm{C}$. Considerando tal valor, pode-se afirmar que a formação de $\mathrm{H}_{2} \mathrm{~S}$ no biogás, de acordo com esta lei, pode reduzir significativamente a concentração de $\mathrm{H}_{2} \mathrm{~S}$ em solução.

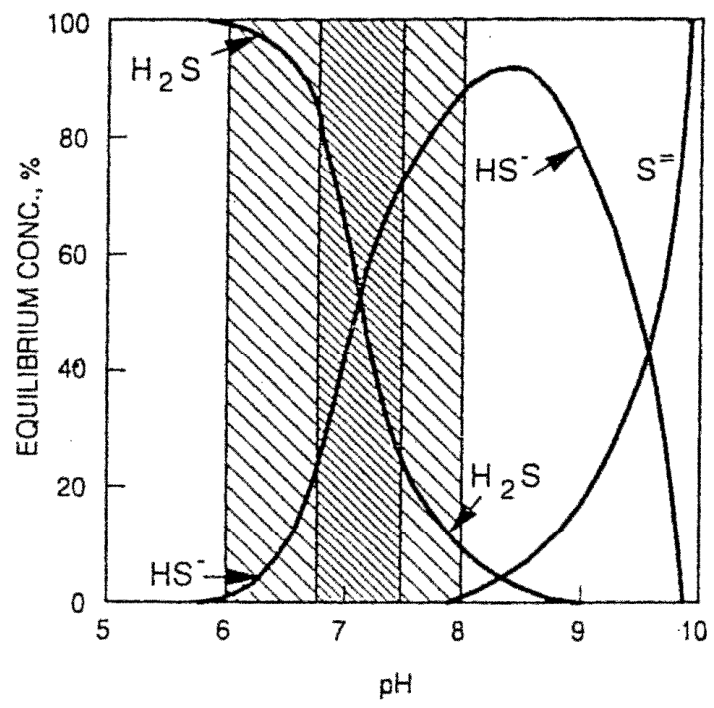

Figura 1 - Distribuição das formas de sulfeto para diferentes valores de $\mathrm{pH}$ : $(\nabla)$ faixa de $\mathrm{pH}$ da digestão anaeróbia e $(\mathbb{\mathbb { N }}) \mathrm{pH}$ ótimo para digestão metanogênica.

Fonte: Lens et al. (1998).

De acordo com Garbossa (2006), a concentração de $\mathrm{H}_{2} \mathrm{~S}$ presente no biogás varia diretamente em função da concentração de compostos oxidados de enxofre contidos na água residuária a ser tratada anaerobiamente. Ele ainda ressalta que a parcela de $\mathrm{H}_{2} \mathrm{~S}$ para esgoto sanitário é menor que $1 \%$ do total de biogás produzido.

Inicialmente, Hulshoff Pol et al., (1998) sugeriram a utilização de sulfetos no processo de desnitrificação de águas residuárias afirmando que os metabolismos do enxofre e do nitrogênio interagem em vários níveis do tratamento, sendo possível integrar a remoção de nitrogênio ao ciclo do enxofre. Além disso, Beristain-Cardoso et al. (2006) afirmam que a utilização de nitrato para controlar a corrosão e os maus odores causados pelo sulfeto em redes de esgoto é uma alternativa conhecida e muito interessante comercialmente. 
Em águas residuárias contendo compostos de nitrogênio e enxofre, o nitrato gerado na nitrificação pode ser recirculado para a fase anaeróbia de tratamento, com a finalidade de promover simultaneamente a oxidação de sulfetos e desnitrificação de nitratos (Vaiopoulou et al.,2005). Esta concepção vem sendo investigada para o tratamento de efluentes industriais (Manconi et al., 2007; Vaiopoulou et al.,2005; Kleerebezem e Mendez, 2002).

Segundo Zhang e Lampe (1999), a desnitrificação autotrófica utilizando compostos de enxofre como doadores de elétrons ocorre por meio da ação de bactérias oxidadoras do enxofre, tais como Thiobacillus denitrificans e Thiomicrospira denitrificans. Tais bactérias quimiolitotróficas são capazes de oxidar compostos reduzidos de enxofre como sulfeto, sulfito, tiossulfato, assim como enxofre elementar, a sulfato, ao mesmo tempo em que reduzem nitrato a nitrogênio gasoso (Moon et al., 2004). Krishnakumar e Manilal (1999) ainda salientam que essas bactérias apresentam requerimento nutricional simples, o que torna vantajosa sua utilização. Segundo Beristain-Cardoso et al. (2006), o processo de oxidação de compostos de enxofre realizado por tais microorganismos também pode se proceder em condições aeróbias.

De acordo com Mahmood et al. (2007), a redução de nitrato utilizando sulfeto como fonte de energia pode ser representada pela equação (5), tendo como produtos finais sulfato e $\mathrm{N}_{2}$.

$$
\begin{aligned}
& 5 \mathrm{HS}^{-}+8 \mathrm{NO}_{3}^{-}+3 \mathrm{H}^{+} \rightarrow 5 \mathrm{SO}_{4}^{2-}+4 \mathrm{~N}_{2}+4 \mathrm{H}_{2} \mathrm{O} \\
& \Delta G_{m}^{\theta}=-3848 \mathrm{~kJ} / \mathrm{mol}
\end{aligned}
$$

Todavia, a oxidação de sulfeto pode ocorrer parcialmente a enxofre elementar, de acordo com a equação (6) apresentada por Klerebeezem e Mendez (2002). De acordo com Jassen et al. (1999), o enxofre elementar, por ser insolúvel, pode ser removido fisicamente do efluente para reuso, por exemplo para a produção de ácido sulfúrico. 


$$
\begin{aligned}
& \mathrm{HS}^{-}+0,4 \mathrm{NO}_{3}^{-}+1,4 \mathrm{H}^{+} \rightarrow \mathrm{S}^{0}+0,2 \mathrm{~N}_{2}+1,2 \mathrm{H}_{2} \mathrm{O} \\
& \Delta G^{o^{\prime}}=-412,7 \mathrm{~kJ} / \text { reação }
\end{aligned}
$$

A desnitrificação autotrófica completa também pode ocorrer a partir de enxofre elementar, conforme a equação (7), descrita por Sierra-Alvarez et al. (2007). Neste caso, observa-se que alcalinidade é consumida, ao contrário dos casos em que sulfeto é oxidado.

$$
\begin{aligned}
& \mathrm{S}^{0}+1,2 \mathrm{NO}_{3}^{-}+0,4 \mathrm{H}_{2} \mathrm{O} \rightarrow \mathrm{SO}_{4}^{2-}+0,6 \mathrm{~N}_{2}+0,8 \mathrm{H}^{+} \\
& \Delta G^{o^{\prime}}=-547,6 \mathrm{~kJ} / \text { reação }
\end{aligned}
$$

Vale ressaltar que a desnitrificação completa a sulfato pode não ser adequada para águas residuárias que contenham naturalmente altas concentrações de sulfato, devido à contribuição para o aumento significativo do sulfato no efluente.

Reyes-Ávila et al. (2004) avaliaram a remoção biológica simultânea de carbono, nitrogênio e enxofre sob diferentes condições de desnitrificação bem definidas. Foi utilizado um reator anaeróbio contínuo sob agitação com volume de 1,3 L e tempo de detenção hidráulica de 2 d. Foram adicionadas cargas de acetato $\left(0,29 \mathrm{kgC} \cdot \mathrm{m}^{-3} \cdot \mathrm{d}^{-1}\right)$ e nitrato $(0,2$ $\mathrm{kgN} \cdot \mathrm{m}^{-3} \cdot \mathrm{d}^{-1}$ ) com a relação $\mathrm{C} / \mathrm{N}$ equivalente a 1,45 . Sob condições estáveis de desnitrificação, a eficiência da remoção de carbono e de nitrogênio atingiu valores maiores que 90\%. Posteriormente, o reator foi alimentado com diferentes cargas de sulfeto $(0,042-0,294 \mathrm{~kg}$ sulfeto. $\left.\mathrm{m}^{-3} \cdot \mathrm{d}^{-1}\right)$, a fim de ser avaliado o seu desempenho nessas condições. A eficiência de remoção de nitrato manteve-se elevada. Porém, a eficiência da remoção de carbono decresceu para $65 \%$.

Em um trabalho realizado por Soares (2002), a desnitrificação autotrófica em reatores com biomassa imobilizada, tendo apenas enxofre elementar granular como doador de elétrons, foi avaliada em laboratório. O reator foi alimentado com uma solução contendo carbono inorgânico solúvel, na forma de bicarbonato de sódio, que era a fonte de carbono fornecida 
aos microorganismos. A solução também foi enriquecida com nitrato e fosfato. $\mathrm{O}$ experimento ocorreu na ausência de luz, à temperatura de $24^{\circ} \mathrm{C} \pm 1{ }^{\circ} \mathrm{C}$. A velocidade máxima de nitrogênio removido foi de $0,20 \mathrm{kgN} \cdot \mathrm{m}^{-3} \mathrm{~d}^{-1}$, com tempo de detenção hidráulica de $1 \mathrm{~h} \mathrm{e}$ carga de nitrato correspondente a $0,24 \mathrm{kgN} \cdot \mathrm{m}^{-3} \cdot \mathrm{d}^{-1}$. O autor concluiu que o sistema de desnitrificação estudado foi extremamente simples, estável e de fácil manutenção.

Beristain-Cardoso et al. (2006) investigaram a fisiologia e cinética da desnitrificação quimiolitotrófica utilizando sulfeto de hidrogênio, enxofre elementar ou tiossulfato como doadores de elétrons. A atividade metabólica do processo foi consideravelmente maior com o uso de tiossulfato em comparação com os outros compostos. Foi observada a completa oxidação de sulfeto a sulfato quando as concentrações de nitrato foram iguais ou superiores em relação ao requerido estequiometricamente. Quando as concentrações de nitrato foram limitantes, ocorreu somente oxidação parcial de sulfeto a enxofre elementar. O aumento da concentração de sulfeto de 2,5 a $10 \mathrm{mM}$ inibiu os processos de conversão do nitrato e geração de sulfato. Os autores concluíram que a velocidade de desnitrificação e sulfo-oxidação depende fortemente dos compostos inorgânicos de enxofre utilizados como doadores de elétrons.

Uma pesquisa realizada por Brunet e Garcia (1996) consistiu na utilização de diferentes compostos de enxofre $\left(\mathrm{H}_{2} \mathrm{~S}, \mathrm{FeS}, \mathrm{S}_{2} \mathrm{O}_{2}{ }^{-3}\right)$ como doadores de elétrons para a remoção, em laboratório, do nitrato presente em sedimentos de uma represa. Observou-se a ocorrência de desnitrificação em baixas concentrações de sulfeto. Porém, em altas concentrações observou-se a redução dissimilativa de nitrato a amônia (RDNA) e desnitrificação incompleta. Os autores afirmam que a ocorrência da RDNA está relacionada à concentração inicial de sulfeto, a qual poderia causar a inibição da NO-redutase ou $\mathrm{N}_{2} \mathrm{O}$ redutase, levando os compostos oxidados de nitrogênio à amônia. 
Em um trabalho realizado por Krishnakumar e Manilal (1999), foi avaliada a desnitrificação autotrófica por Thiobacillus denitrificans na presença de sulfeto utilizando-se biomassa suspensa. Observou-se que a oxidação do sulfeto pelo processo de desnitrificação foi relevante após $2 \mathrm{~h}$, tendo continuidade até o consumo completo de sulfeto. Porém, em condições limitantes de nitrato, a reação de oxidação foi incompleta. Em alguns ensaios, durante a oxidação, a solução tornou-se branca devido ao acúmulo de enxofre elementar. Análises demonstraram que cerca de 40 a $60 \%$ do sulfeto foi convertido a sulfato e o restante a enxofre elementar. A velocidade de oxidação bacteriana de sulfeto seguiu uma reação de ordem zero, isto é, não foi afetada pela concentração do substrato, e o valor obtido ficou em torno de $0,9 \mathrm{~g}$ sulfeto.gSSV${ }^{-1} \cdot \mathrm{h}^{-1}$. Os valores de $\mathrm{pH}$ foram elevados de 7,5 para 8,0 durante a oxidação incompleta do sulfeto, em função da formação de enxofre elementar. Observou-se também acúmulo de nitrito, o que pode ser devido ao retardo no início da ação das enzimas redutoras de nitrito na presença de nitrato, tipo de bactéria, inibição pela presença de nitrato em relação ao nitrito, entre outros fatores.

Garbossa (2006) realizou ensaios em batelada de desnitrificação com biomassa imobilizada de Reator Misto Radial de Leito Fixo (RMRLF) utilizando sulfeto de sódio como doador de elétrons. A alimentação foi feita utilizando água residuária sintética simulando efluente nitrificado de reator biológico anaeróbio. Foi verificado que houve grande aumento nos valores do $\mathrm{pH}$, de 7,5 $\pm 0,4$ a $8,2 \pm 1,3$. A quantidade de nitrato removido do sistema correspondia à produção de nitrogênio gasoso, numa relação 1,2:1. Após a fase de adaptação dos reatores, foram obtidos parâmetros cinéticos da desnitrificação, e foi concluído que o consumo de nitrato pode ser representado por uma reação de ordem zero.

Vaiopoulou et al. (2005) avaliaram a utilização da desnitrificação autotrófica, em escala piloto, para remoção de sulfeto e nitrogênio de águas residuárias de indústrias petroquímicas. O sistema de tratamento possuía múltiplos estágios e foi alimentado com uma 

ao tratamento de esgoto sanitário

mistura contendo efluente de refinarias, efluente nitrificado e sulfeto de sódio. O processo ocorreu com sucesso, sendo que $110 \mathrm{mg}$ sulfeto. $\mathrm{L}^{-1}$ foram totalmente convertidos a $\mathrm{SO}_{4}{ }^{2-}$, restando no efluente uma concentração residual inferior a $0,1 \mathrm{mg}$ sulfeto. $\mathrm{L}^{-1}$. A implantação prática deste processo biológico combinado com a remoção física obtida pela injeção de $\mathrm{CO}_{2}$ (stripping) para remoção de sulfeto já existente na refinaria possibilitou a redução de $70 \%$ na demanda de energia para a compressão do gás $\mathrm{CO}_{2}$ e, conseqüentemente, a redução de custos.

Manconi et al. (2007) investigaram a desnitrificação autotrófica por meio de culturas suspensas de Thiobacillus denitrificans, utilizando compostos de enxofre como doadores de elétrons em sistema de lodos ativados. Com o uso de sulfeto, a eficiência atingida foi superior a $90 \%$ na remoção de nitrogênio quando o reator foi operado em baixos valores de N/S (0,50,9), ou seja, quando foram aplicadas concentrações excessivas de sulfeto. Quando a concentração de sulfeto foi limitante $(\mathrm{N} / \mathrm{S}=1,8)$, a eficiência da remoção de nitrogênio decresceu para $60 \%$. Em todas as condições testadas foi observado consumo completo de sulfeto, com a formação de sulfato como principal produto e enxofre elementar como intermediário. Este último foi formado nas condições em que foi aplicado sulfeto em excesso, sendo observada alteração na coloração do líquido no interior do reator, o qual se tornou turvo e esbranquiçado.

Kleerebezem e Mendez (2002) propuseram um esquema alternativo de tratamento de águas residuárias de indústrias processadoras de peixe, as quais são ricas em matéria orgânica biodegradável, amônia e sulfato. Este sistema combinou a remoção de sulfeto de hidrogênio presente no biogás do processo anaeróbio anterior e a pós-desnitrificação autotrófica para eliminação de nitrato. Foi demonstrado que o biogás gerado no pré-tratamento anaeróbio do efluente utilizado continha sulfeto suficiente para a desnitrificação autotrófica subseqüente. Foram realizados experimentos em reator de filme fixo em escala laboratorial. Os parâmetros cinéticos estimados para a desnitrificação autotrófica com o uso de sulfetos não apresentaram 
limitações à aplicação do processo. O balanço de massa demonstrou a ocorrência de acúmulo de enxofre elementar, devido à incompleta oxidação do sulfeto, quando o reator foi alimentado com elevadas cargas de sulfeto. Os autores ainda ressaltaram a importância de maiores pesquisas a respeito da cinética deste processo.

Pérez et al. (2007) propuseram o processo de nitrificação/desnitrificação autotrófica via nitrito utilizando sulfetos como doadores de elétrons para o pós-tratamento de efluente de digestor de lodo de esgoto sanitário. Foi utilizado reator de batelada seqüencial (RBS), em escala laboratorial, contendo biomassa suspensa. Sulfeto de sódio hidratado era injetado em concentrações equivalentes a $80-85 \%$ da estequiométrica para evitar a oxidação do excesso de sulfeto a enxofre elementar nos períodos aerados. Entretanto, este fato ocasionou acúmulo de

nitrito residual $\left(30 \mathrm{mgN}-\mathrm{NO}_{2}{ }^{-} \cdot \mathrm{L}^{-1}\right)$, que poderia não representar problema se o efluente fosse recirculado à planta principal para melhor remoção. A eficiência de remoção de nitrogênio alcançada foi maior que $95 \%$, sendo obtida remoção total de $0,70 \mathrm{kgN} \cdot \mathrm{m}^{-3} \mathrm{~d}^{-1}$.

\subsection{CONSIDERAÇÕES FINAIS}

A revisão da literatura efetuada permitiu concluir que a desnitrificação utilizando compostos de enxofre como fonte de doadores de elétrons é um processo não totalmente elucidado. Porém, sabe-se que esta alternativa pode implicar na redução de custos requeridos para remoção de nitrogênio, já que a adição de fonte externa de carbono pode ser eliminada ou reduzida. As lacunas na literatura são particularmente significativas no que se refere ao uso da desnitrificação autotrófica utilizando compostos reduzidos de enxofre para a remoção de nitrogênio de esgotos sanitários. Desse modo, este projeto visa contribuir para a ampliação do conhecimento acerca do processo de desnitrificação na presença de sulfeto, avaliando a viabilidade de aplicação do referido processo a efluentes de reatores anaeróbios tratando esgoto sanitário. 


\section{MATERial e MÉtodos}

Os experimentos desta pesquisa foram estruturados e operados nas dependências do Laboratório de Processos Biológicos (LPB) do Departamento de Hidráulica e Saneamento (SHS) da Escola de Engenharia de São Carlos (EESC), Universidade de São Paulo (USP).

\subsection{DESENHO EXPERIMENTAL}

Basicamente, os ensaios foram divididos em duas fases, conforme esquematizado na Figura 2. As etapas estão descritas a seguir de forma geral e resumida. Durante tais experimentos também foram realizados exames microscópicos para avaliação da diversidade microbiana presente nos reatores, os quais envolveram todas as condições testadas.

$\boldsymbol{F A S E} 1$ - Esta primeira etapa foi realizada para a verificação da ocorrência da desnitrificação autotrófica em efluente sintético simulando água residuária nitrificada, utilizando sulfeto como doador de elétrons. Após o período de adaptação, foi verificada a relação entre as concentrações de nitrato e sulfeto dissolvido (N/S) mais adequada ao alcance da estabilidade dos reatores. Atingida a estabilidade operacional, com aplicação de sulfeto em excesso, foram realizados perfis temporais para o ajuste de modelos cinéticos relativos ao consumo de nitrogênio na forma de nitrato $\left(\mathrm{N}^{-\mathrm{NO}_{3}}{ }^{-}\right)$. $\mathrm{O}$ mesmo procedimento foi realizado com o uso de nitrito em substituição ao nitrato, para verificação da desnitrificação pela via curta.

$\boldsymbol{F A S E} 2$ - Nesta fase foi verificada a ocorrência da desnitrificação autotrófica em uma mistura de efluente sintético nitrificado e de efluente real não nitrificado proveniente de reator UASB tratando água residuária de abatedouro de aves. Esse tipo de ensaio pretendeu simular os processos de remoção de nitrogênio quando somente parte do efluente do reator anaeróbio é submetido ao processo de nitrificação. A adaptação da biomassa ocorreu de forma idêntica à 
primeira fase, utilizando a mesma água residuária. Após a adaptação, a água residuária foi substituída pela mistura de efluentes (nova condição) e os reatores foram monitorados para verificação da relação entre as concentrações de nitrato e sulfeto dissolvido (N/S) que possibilitou o alcance da estabilidade operacional. Isto ocorreu com a aplicação de solução de sulfeto na concentração estequiométrica com relação a $\mathrm{N}_{-} \mathrm{NO}_{3}{ }^{-}$. Em seguida, foram realizados perfis temporais para o ajuste de modelos cinéticos relativos ao consumo de $\mathrm{N}_{-} \mathrm{NO}_{3}{ }^{-}$.

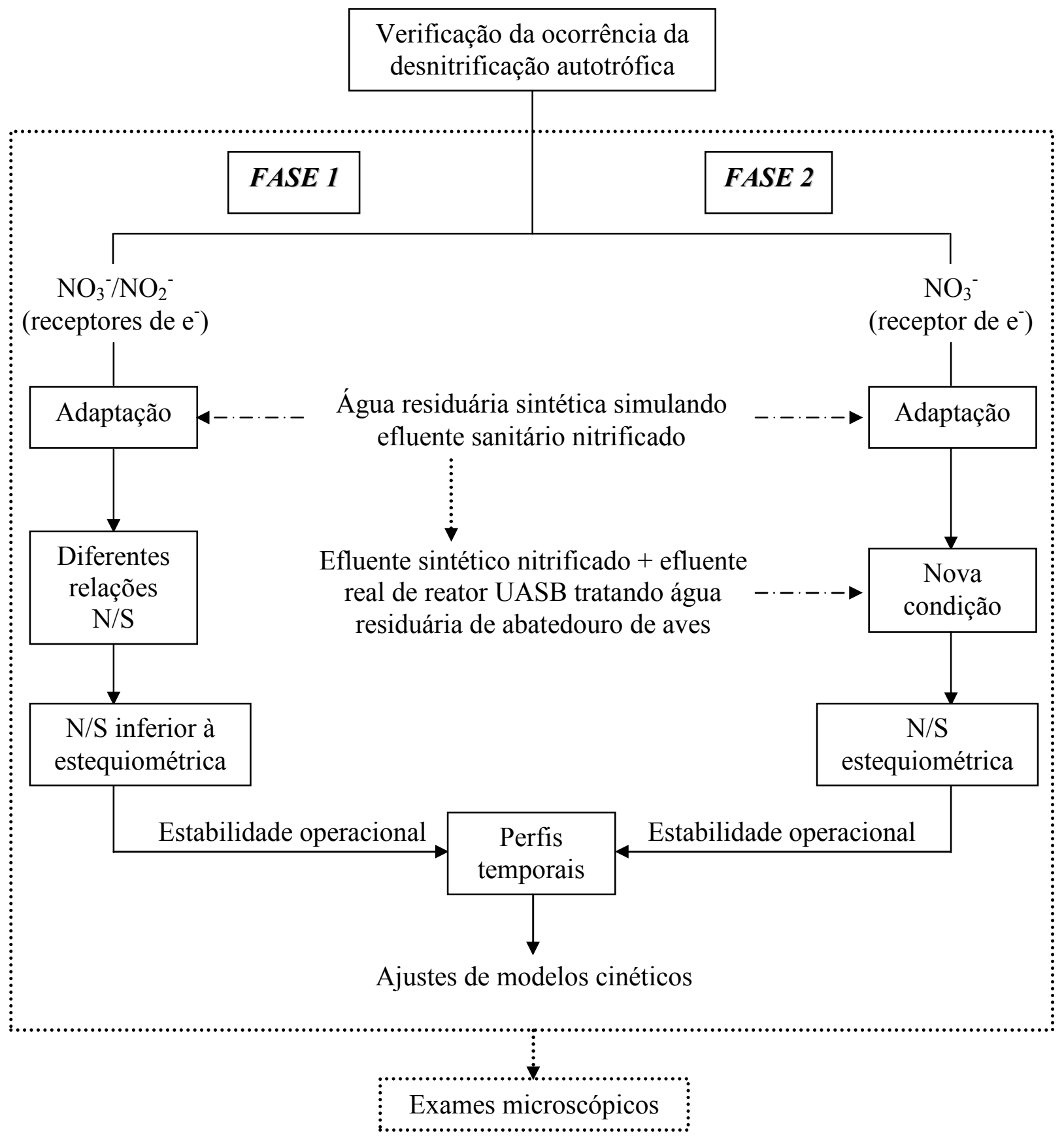

Figura 2 - Fluxograma do procedimento experimental 


\subsection{DESCRIÇÃO DOS REATORES DESNITRIFICANTES OPERADOS EM BATELADA}

Os reatores anóxicos, operados em batelada, consistiram em três frascos de vidro Duran de 1 L (RI1, RI2 e RI3), com tampas do tipo rosca, as quais continham um centro com septo emborrachado para permitir a colocação de agulhas a fim de dosar soluções e coletar amostras (Figura 3). Foram inoculados 100 cubos de espuma de poliuretano de $1 \mathrm{~cm}$ de aresta, com massa previamente conhecida $\mathrm{O}$ volume útil reacional foi próximo de $700 \mathrm{~mL}$, incluindo o valor do volume de líquido que era absorvido pelas espumas entre as trocas do meio líquido (aproximadamente $100 \mathrm{~mL}$ ). Dessa forma, o volume de água residuária medido, que era adicionado aos frascos nas trocas do líquido no interior dos mesmos, correspondia a cerca de $600 \mathrm{~mL}$. Havia pequena variação do volume útil reacional em função da forma pela qual era realizada a alimentação, que incluía a adição diária de pequenos volumes de soluções, por meio de seringas através do septo emborrachado, e a troca completa do meio líquido apenas duas vezes por semana. Para melhor entendimento deste processo, no item 4.8 está detalhado o procedimento de alimentação dos reatores, envolvendo a freqüência e a forma de fornecimento dos substratos.

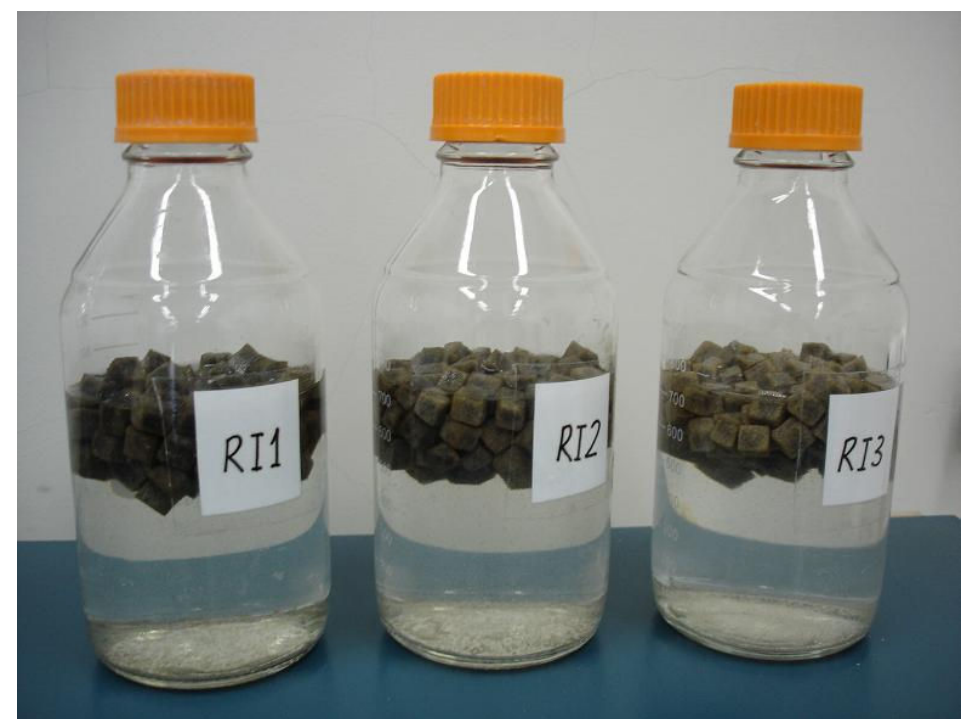

Figura 3 - Reatores desnitrificantes operados em batelada (RI1, RI2, RI3). 
Os reatores foram mantidos em incubadora climatizada com temperatura controlada de $30^{\circ} \mathrm{C} \pm 1^{\circ} \mathrm{C}$, sob agitação inicial de $50 \mathrm{rpm}$, a qual foi gradualmente aumentada até atingir-se $120 \mathrm{rpm}$, sendo observado pouco desprendimento da biomassa. Na primeira condição testada da primeira fase, atmosfera anóxica foi obtida por meio do fluxionamento com gás hélio, o qual foi substituído por uma mistura de gases $\mathrm{N}_{2} / \mathrm{CO}_{2}$ na proporção de 30:70\%, respectivamente, para que fosse mantido $\mathrm{pH}$ em torno de 7-7,5. A duração do fluxionamento era de pelo menos 10 minutos.

\subsection{ALIMENTAÇÃO DOS REATORES}

\subsection{1. Água residuária sintética}

A água residuária utilizada na primeira fase da pesquisa simulava efluente nitrificado típico de tratamento de águas residuárias municipais, similar ao apresentado por Callado \& Foresti (2000). Porém, foram feitas algumas adaptações de forma a criar melhores condições ao crescimento dos microrganismos autotróficos, sendo mantida a concentração de $\mathrm{N}^{-\mathrm{NO}_{3}}{ }^{-}$ originalmente contida neste tipo de efluente $\left(20 \mathrm{mgN} \cdot \mathrm{L}^{-1}\right)$. A aplicação de solução de sulfeto ocasionava grande elevação do $\mathrm{pH}$, e a concentração de bicarbonato de sódio $\left(\mathrm{NaHCO}_{3}\right)$ aplicada inicialmente $\left(300 \mathrm{mg} \cdot \mathrm{L}^{-1}\right)$, com base nos autores supracitados, era insuficiente para tamponar o meio líquido. Desse modo, a concentração de $\mathrm{NaHCO}_{3}$ foi aumentada para 2000 mg. $\mathrm{L}^{-1}$ no decorrer dos experimentos, para que o $\mathrm{pH}$ neutro fosse mantido. Tal valor foi baseado em Beristain-Cardoso et al. (2006). A solução de uréia foi substituída por cloreto de amônio $\left(\mathrm{NH}_{4} \mathrm{Cl}\right)$, sendo mantida a mesma concentração de nitrogênio amoniacal contida no efluente sintético nitrificado. A solução de micronutrientes utilizada foi a proposta por Beristain-Cardoso et al., (2006), com concentração de $2 \mathrm{~mL} \cdot \mathrm{L}^{-1}$. A composição da água 
residuária é apresentada na Tabela 1 e a composição dos micronutrientes presentes na mesma pode ser visualizada na Tabela 2.

Tabela 1 - Composição da água residuária sintética nitrificada.

\begin{tabular}{cc}
\hline Constituinte & Concentração \\
\hline Nitrato de potássio $\left(\mathrm{KNO}_{3}\right) /$ nitrito de sódio $\left(\mathrm{NaNO}_{2}\right)$ & $144 / 99 \mathrm{mg} . \mathrm{L}^{-1}$ \\
Fosfato de potássio $\left(\mathrm{KH}_{2} \mathrm{PO}_{4}\right)$ & $36 \mathrm{mg} . \mathrm{L}^{-1}$ \\
Cloreto de amônio $\left(\mathrm{NH}_{4} \mathrm{Cl}\right)$ & $16 \mathrm{mg} . \mathrm{L}^{-1}$ \\
Bicarbonato de sódio $\left(\mathrm{NaHCO}_{3}\right)$ & $2000 \mathrm{mg} . \mathrm{L}^{-1}$ \\
Cloreto de magnésio hidratado $\left(\mathrm{MgCl}_{2} \cdot 6 \mathrm{H}_{2} \mathrm{O}\right)$ & $28 \mathrm{mg} . \mathrm{L}^{-1}$ \\
Cloreto de cálcio hidratado $\left(\mathrm{CaCl}_{2} \cdot 2 \mathrm{H}_{2} \mathrm{O}\right)$ & $18 \mathrm{mg} \cdot \mathrm{L}^{-1}$ \\
\hline
\end{tabular}

Fonte: Callado \& Foresti (2000) adaptado.

Tabela 2 - Composição dos micronutrientes presentes na água residuária.

\begin{tabular}{cc}
\hline Constituinte & Concentração $\left(\mathbf{m g . L ^ { - 1 }}\right)$ \\
\hline $\mathrm{EDTA}$ & 1,667 \\
$\mathrm{ZnSO}_{4} \cdot 7 \mathrm{H}_{2} \mathrm{O}$ & 0,133 \\
$\mathrm{CaCl}_{2} \cdot 2 \mathrm{H}_{2} \mathrm{O}$ & 0,233 \\
$\mathrm{MnCl}_{2}$ & 0,100 \\
$\left(\mathrm{NH}_{4}\right)_{6} \mathrm{Mo}_{7} \mathrm{O}_{24} \cdot 4 \mathrm{H}_{2} \mathrm{O}$ & 0,033 \\
$\mathrm{CuSO}_{4} \cdot \mathrm{H}_{2} \mathrm{O}$ & 0,067 \\
$\mathrm{CoCl}_{2} \cdot 6 \mathrm{H}_{2} \mathrm{O}$ & 0,067 \\
\hline
\end{tabular}

Para os ensaios em que o nitrito foi o receptor de elétrons, a solução de $\mathrm{KNO}_{3}$ foi substituída por $\mathrm{NaNO}_{2}$, mantendo-se a mesma concentração de nitrogênio $\left(20 \mathrm{mgN} . \mathrm{L}^{-1}\right)$. Ambas as soluções eram fornecidas separadamente por meio de seringas, a fim de manter a mesma precisão de medida com relação ao doador de elétrons injetado, o sulfeto. A solução de sulfeto era injetada separadamente para que as perdas da parcela solúvel deste composto 
fossem minimizadas. $\mathrm{O}$ fornecimento deste doador de elétrons está descrito no item 4.3.3. $\mathrm{O}$ mesmo procedimento foi seguido com a solução de bicarbonato de sódio $\left(\mathrm{NaHCO}_{3}\right)$, em função do fluxionamento com $\mathrm{N}_{2} / \mathrm{CO}_{2}$, o qual poderia causar alterações na forma química do $\mathrm{NaHCO}_{3}$.

\subsection{2 Água residuária}

$\mathrm{Na}$ segunda etapa da pesquisa, os reatores foram alimentados com uma mistura de água residuária sintética e real contendo formas oxidadas e reduzidas de nitrogênio e enxofre, em diferentes proporções. A água residuária sintética nitrificada utilizada foi similar à utilizada na primeira fase (Tabelas 1 e 2). O efluente real utilizado foi proveniente de reator UASB tratando água residuária de abatedouro de aves. Tal efluente foi diluído 2,5 vezes a fim de apresentar composição semelhante à de efluente de reator anaeróbio tratando esgoto sanitário. A composição do efluente de abatedouro de aves sem diluição está caracterizada na Tabela 3. O pH também foi medido, tendo sido encontrado valor médio em torno de 7,0.

Não havia informações a respeito da concentração de sulfeto dissolvido originalmente contida na água residuária, sendo que parte do mesmo foi perdida para o ambiente na forma gasosa durante o transporte e armazenamento do efluente, de acordo com o equilíbrio químico entre as espécies de sulfeto, detalhado no item 3.2.1. Desse modo, foi escolhida a concentração de $30 \mathrm{mg}$ sulfeto. $\mathrm{L}^{-1}$ a ser adicionada ao efluente do reator anaeróbio do abatedouro de aves. Optou-se por este valor para que fosse possível misturar este efluente com o efluente sintético nitrificado em iguais proporções, mantendo-se a relação N/S estequiométrica $(1,6)$. Não foi possível basear-se em um valor médio da literatura visto que os dados a respeito da concentração de sulfeto presente em efluentes anaeróbios são bastante discrepantes. 
Nesta fase, as soluções de $\mathrm{KNO}_{3}$ e de $\mathrm{NaHCO}_{3}$ também foram fornecidas separadamente por meio de seringas.

Tabela 3 - Caracterização do efluente real de reator anaeróbio tratando água residuária de abatedouro de aves utilizado.

\begin{tabular}{|c|c|c|c|}
\hline Parâmetro & & ção & \\
\hline $\mathrm{DQO}_{\text {total }}$ & 453,88 & \pm & 0,00 \\
\hline $\mathrm{DQO}_{\text {filtrada }}$ & 198,67 & \pm & 39,98 \\
\hline Alcalinidade $\left(\mathrm{mgCaCO}_{3} \cdot \mathrm{L}^{-1}\right)$ & 581,54 & \pm & - \\
\hline Ácidos voláteis (mgHac.L $\left.{ }^{-1}\right)$ & 66,42 & \pm & - \\
\hline $\mathrm{N}-\mathrm{NO}_{3}^{-}$ & 0,00 & \pm & - \\
\hline $\mathrm{N}-\mathrm{NO}_{2}^{-}$ & 0,00 & \pm & - \\
\hline $\mathrm{N}-\mathrm{NH}_{4}{ }^{+}$ & 151,80 & \pm & - \\
\hline $\mathrm{S}^{2-} / \mathrm{HS}^{-} / \mathrm{H}_{2} \mathrm{~S}$ & 0,34 & \pm & 0,01 \\
\hline $\mathrm{SO}_{4}{ }^{2-}$ & 37,41 & \pm & 1,38 \\
\hline STV & 0,43 & \pm & 0,02 \\
\hline STF & 0,45 & \pm & 0,33 \\
\hline SSV & 0,16 & \pm & 0,03 \\
\hline SSF & 0,10 & \pm & 0,00 \\
\hline SDV & 0,22 & \pm & 0,03 \\
\hline SDF & 1,01 & \pm & 0,13 \\
\hline
\end{tabular}

\subsubsection{Sulfeto de sódio fornecido como doador de elétrons}

Visto que as espécies de sulfeto em solução são formadas de acordo com o equilíbrio químico estabelecido (item 3.2.1), a concentração de sulfeto foi convenientemente expressa em termos de sulfeto dissolvido total (SDT), conforme a equação (8).

$$
\operatorname{SDT}\left(m g S \cdot L^{-1}\right)=H_{2} S_{(a q)}+H S_{(a q)}^{-}+S_{(a q)}^{2-}
$$


Vale ressaltar que a forma ionizada $\mathrm{S}^{2-}$ possivelmente não estava presente no interior dos reatores, já que a faixa de $\mathrm{pH}$ do meio líquido era próxima à neutralidade e esta espécie de sulfeto é mais estável em valores de pH alcalino.

O sulfeto foi fornecido na forma de solução de sulfeto de sódio hidratado $\left(\mathrm{Na}_{2} \mathrm{~S} .9 \mathrm{H}_{2} \mathrm{O}\right)$, sendo injetada através do septo emborrachado localizado na tampa dos frascos. Inicialmente, na primeira fase, a adição de sulfeto visava à obtenção de baixa concentração nos frascos, abaixo da relação estequiométrica relativamente a nitrato. Posteriormente, foi utilizada a concentração requerida na proporção estequiométrica, a qual foi gradualmente aumentada até que as concentrações dos compostos de interesse, ao final dos ciclos, ficassem praticamente constantes. Quando foi utilizado nitrito como receptor de elétrons, ainda na primeira fase, a concentração de solução de sulfeto aplicada inicialmente foi equivalente à relação N/S estequiométrica relativa a sulfeto e nitrito, sendo dobrada posteriormente a fim de ser alcançada a estabilidade operacional dos reatores. Na segunda fase da pesquisa, após o período de adaptação, isto é, na nova condição, foi utilizada apenas a concentração

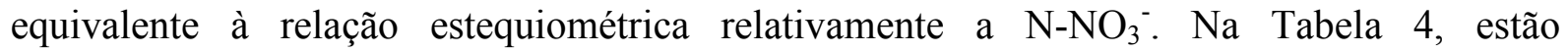
apresentadas as concentrações de sulfeto aplicadas nos reatores com as respectivas relações N/S e concentrações dos receptores de elétrons correspondentes, para ambas as etapas da pesquisa. 
Tabela 4 - Concentrações teóricas do doador e dos receptores de elétrons correspondentes às relações $\mathrm{N} / \mathrm{S}$ aplicadas nas duas fases na pesquisa.

\begin{tabular}{|c|c|c|c|c|}
\hline & $\begin{array}{l}\text { Receptor de } \\
\text { elétrons }\end{array}$ & $\begin{array}{c}\text { Condição } \\
\text { N/S }\end{array}$ & $\begin{array}{c}\text { SDT } \\
\left(\mathrm{mgS.L}^{-1}\right)\end{array}$ & $\begin{array}{l}\mathrm{N}-\mathrm{NO}_{\mathrm{x}}^{-} \\
\left(\mathrm{mg} . \mathrm{L}^{-1}\right)\end{array}$ \\
\hline \multirow{6}{*}{ Fase 1} & $\mathrm{~N}-\mathrm{NO}_{3}{ }^{-}$ & 4,8 & 10 & 20 \\
\hline & $\mathrm{N}-\mathrm{NO}_{3}{ }^{-}$ & 1,6 & 30 & 20 \\
\hline & $\mathrm{N}-\mathrm{NO}_{3}{ }^{-}$ & 1,2 & 40 & 20 \\
\hline & $\mathrm{N}-\mathrm{NO}_{3}{ }^{-}$ & 0,8 & 60 & 20 \\
\hline & $\mathrm{N}-\mathrm{NO}_{2}^{-}$ & 2,7 & 17 & 20 \\
\hline & $\mathrm{N}-\mathrm{NO}_{2}^{-}$ & 1,4 & 34 & 20 \\
\hline Fase 2 & $\mathrm{~N}-\mathrm{NO}_{3}{ }^{-}$ & 1,6 & 15 & 10 \\
\hline
\end{tabular}

\subsection{LODO DE INÓCULO}

O inóculo utilizado consistiu em lodo proveniente de reator UASB da Estação de Tratamento de Águas Residuárias de Abatedouro de Aves, da Avícola Dacar S.A., localizada em Tietê - SP. Este lodo de inóculo foi escolhido devido à sua diversidade microbiana, conforme avaliada e caracterizada por Hirasawa (2008).

O lodo foi imobilizado em matrizes cúbicas de espuma de poliuretano conforme descrito no item 4.8.5.

\subsection{ANÁLISES FÍSICO-QUÍMICAS}

Os parâmetros analisados durante a fase experimental, assim como as metodologias, encontram-se apresentados na Tabela 5. Todas as análises apresentadas foram realizadas de acordo com técnicas descritas no Standard Methods for the Examination of Water and Wastewater (2005), exceto as análises dos compostos de nitrogênio, baseadas na metodologia de análise por injeção de fluxo (FIA). 
Tabela 5 - Parâmetros e metodologia de análise

\begin{tabular}{cc} 
Parâmetro/Unidade & Metodologia \\
\hline $\mathrm{pH}$ & Potenciométrico \\
$\mathrm{N}^{-\mathrm{NH}_{4}}{ }^{+}\left(\mathrm{mg} \mathrm{N} . \mathrm{L}^{-1}\right)$ & Método do Fenato (FIA) \\
$\mathrm{N}^{-\mathrm{NO}_{2}}{ }^{-}\left(\mathrm{mg} \mathrm{N} . \mathrm{L}^{-1}\right)$ & Colorimétrico (FIA) \\
$\mathrm{N}^{-\mathrm{NO}_{3}}{ }^{-}\left(\mathrm{mg} \mathrm{N} . \mathrm{L}^{-1}\right)$ & Método de redução por cádmio (FIA) e \\
$\mathrm{SSV}\left(\mathrm{mg} . \mathrm{L}^{-1}\right)$ & Espectrofotométrico UV \\
$\mathrm{DQO}\left(\mathrm{mg} . \mathrm{L}^{-1}\right)$ & Gravimétrico \\
$\mathrm{S}-\mathrm{SO}_{4}{ }^{2-}\left(\mathrm{mg} . \mathrm{L}^{-1}\right)$ & Colorimétrico \\
\hline
\end{tabular}

O método de análise por injeção de fluxo (FIA) foi empregado para a quantificação das concentrações de nitrato, nitrito e nitrogênio amoniacal durante o monitoramento e os perfis temporais de concentração por permitir a utilização de menores volumes de amostras.

As determinações das concentrações de sulfeto dissolvido total (SDT) foram realizadas de acordo com a metodologia 8131 (azul de metileno), proposta pela HACH, adaptada. A adaptação consistiu na adição de solução de acetato de zinco $0,1 \mathrm{M}$, com a finalidade de fixar o sulfeto presente na amostra.

Com relação às análises de demanda química de oxigênio (DQO), foram descontadas, dos valores finais, as concentrações de DQO proporcionadas pela presença de sulfeto. Os cálculos foram feitos com base nas reações químicas teóricas.

Para a determinação de sólidos aderidos (mg SVS.g espuma ${ }^{-1}$ ), foram retiradas amostras de espumas do reator e transferidas para um tubo falcon $(15 \mathrm{~mL})$ com água destilada e os sólidos foram removidos com o auxílio de um bastão de vidro. O volume de enxágüe foi filtrado em membrana porosa de $2,5 \mathrm{~mm}$, previamente seca e pesada, e a mesma foi levada à 
estufa por 24 horas, à $100^{\circ} \mathrm{C}$. A determinação da massa das espumas respectivas também foi realizada após secagem em estufa à $100^{\circ} \mathrm{C}$ por 24 horas.

\subsection{MODELAGEM CINÉTICA}

A modelagem cinética foi baseada na remoção de nitrogênio nas formas de nitrato e nitrito, a partir dos perfis temporais de concentração específica do substrato no meio líquido ao longo do tempo, medidos experimentalmente. Para determinar a ordem de reação foi utilizado o método integral, o qual consiste em supor uma determinada ordem e integrar a equação diferencial usada para modelar o sistema em batelada. A consistência da equação resultante, a qual relaciona a concentração do composto de interesse em função do tempo, foi avaliada graficamente, utilizando o método de tentativas e erros.

Considerando o reator em batelada de volume constante, a função de velocidade de reação pode ser descrita de acordo com a equação (9).

$$
\left(-r_{N^{\prime}}\right)=\frac{d C_{N^{\prime}}}{d t}=k \cdot f\left(C_{N^{\prime}}\right)
$$

Em que:

$r_{N^{\prime}}=$ velocidade específica de consumo de nitrogênio $\left(\mathrm{mgN} \cdot \mathrm{L}^{-1} \cdot \mathrm{gSSV}^{-1} \cdot \mathrm{h}^{-1}\right)$;

$C_{N^{\prime}}=$ concentração de nitrogênio por unidade de massa de SSV no tempo $t$ $\left(\mathrm{mgN} \cdot \mathrm{L}^{-1} \cdot \mathrm{gSSV}{ }^{-1}\right)$

$k=$ constante de velocidade dependente da ordem da reação e do modelo cinético;

$f\left(C_{N^{\prime}}\right)=$ função a ser avaliada, dependente da concentração de nitrogênio;

$t=$ tempo (horas) 
As funções avaliadas, obtidas a partir dos perfis de concentração de nitrogênio em função do tempo, consistiram em reações de ordem zero e de primeira ordem. Para uma reação de ordem zero, na qual a velocidade de reação não é afetada pela concentração dos substratos, tem-se a igualdade expressa na equação (10):

$$
\left(-r_{N^{\prime}}\right)=\frac{d C_{N^{\prime}}}{d t}=k_{0}
$$

Em que:

$k_{0}=$ constante cinética específica de ordem zero $\left(\mathrm{mgN} \cdot \mathrm{L}^{-1} \cdot \mathrm{gSSV}^{-1} \cdot \mathrm{h}^{-1}\right)$

Considerando a concentração inicial de nitrogênio $\left(C_{N 0^{\prime}}\right)$ em um tempo $t$ correspondente a $t_{0}$, a equação (10) pode ser integrada entre esses limites, conforme demonstrado na equação (11).

$$
-\int_{C_{N 0^{\prime}}}^{C_{N^{\prime}}} d C_{N^{\prime}}=k_{0} \int_{t_{0}}^{t} d t
$$

A equação integrada, expressa em termos de concentração específica de nitrogênio, pode ser escrita como apresentado na equação (12), a qual indica que a concentração do substrato varia linearmente com o tempo.

$$
C_{N^{\prime}}=C_{N 0^{\prime}}-k_{0} \cdot\left(t-t_{0}\right)
$$

Para uma reação de primeira ordem, a velocidade de reação pode ser escrita conforme a equação (13):

$$
\left(-r_{N^{\prime}}\right)=\frac{d C_{N^{\prime}}}{d t}=k_{1} \cdot C_{N^{\prime}}
$$


Em que:

$k_{1}=$ constante cinética de primeira ordem $\left(\mathrm{h}^{-1}\right)$

Considerando a concentração inicial de nitrogênio $\left(C_{N 0^{\prime}}\right)$ em um tempo $t$ correspondente a $t_{0}$, a equação (13) pode ser integrada entre esses limites, conforme demonstrado na equação (14).

$$
\int_{C_{N 0^{\prime}}}^{C_{N^{\prime}}} \frac{d C_{N^{\prime}}}{C_{N^{\prime}}}=-k_{1} \int_{t_{0}}^{t} d t
$$

A equação integrada, expressa em termos de concentração específica de nitrogênio, pode ser escrita como apresentado na equação (15), a qual indica que a concentração do substrato varia exponencialmente com o tempo.

$$
C_{N^{\prime}}=C_{N 0^{\prime}} \cdot e^{-k_{1} \cdot\left(t-t_{0}\right)}
$$

A avaliação da extensão dos fenômenos físicos de transferência de massa sobre as velocidades de reação obtidas foi realizada por meio de parâmetros adimensionais que relacionam as resistências externa (líquido-sólido) e interna (intraparticular), além da velocidade de reação. Para exemplificar o tratamento dos dados, foram feitas as seguintes considerações: cubo de espuma equivalente a uma partícula esférica com diâmetro de $1 \mathrm{~cm}$; distribuição homogênea da biomassa na estrutura do biofilme; densidade homogênea do meio líquido; sistema isotérmico; fluxo unidirecional dos materiais na biopartícula no sentido do raio.

Os efeitos das limitações impostas pela difusão externa à transferência de massa foram avaliados por meio do número de Biot $(B i)$, definido conforme a equação (16), para partícula esférica. Este parâmetro adimensional relaciona a velocidade de transporte de massa na 
camada líquida estagnada ao redor da partícula com a velocidade de difusão intraparticular. De acordo com Bailey e Ollis (1986), o efeito da resistência externa à transferência de massa não é significativo para $B i \geq 100$.

$$
B i=\frac{k_{s} \cdot R_{p}}{D_{e}}
$$

Em que:

$k_{s}=$ coeficiente de transferência de massa líquido-sólido $\left(\mathrm{cm}^{3} \cdot \mathrm{h}^{-1}\right)$;

$R_{p}=$ raio da biopartícula $\left(\mathrm{cm}^{-1}\right)$

$D_{e}=$ difusividade efetiva do substrato $\left(\mathrm{cm}^{2} \cdot \mathrm{h}^{-1}\right)$.

O valor do coeficiente de transferência de massa líquido-sólido $(k s)$ foi obtido a partir de correlação que associa as propriedades físicas do líquido, características hidrodinâmicas do reator e geométricas das biopartículas. A correlação utilizada, dada pelo fator de Colburn $\left(\mathrm{J}_{\mathrm{D}}^{*}\right)$ para transferência de massa, é apresentada na equação (17), de acordo com Bailey e Ollis (1986).

$$
\mathrm{J}_{\mathrm{D}}^{*}=\mathrm{Sh} \cdot(\mathrm{Sc})^{-1 / 3} \cdot\left(\operatorname{Re}_{\mathrm{p}}^{*}\right)^{-1}
$$

Em que:

$S h=$ número de Sherwood

$S c=$ número de Schimidt

$R_{e p}{ }^{*}=$ número de Reynolds de partícula modificado

O número de Sherwood $(S h)$ relaciona a transferência de massa por convecção com a transferência difusional na fase líquida, o número de Schimidt $(S c)$ relaciona as transferências de quantidade e massa e o número de Reynolds de partícula modificado $\left(R_{e p}{ }^{*}\right)$ é baseado na 
área da seção transversal líquida do reator. Essas grandezas adimensionais são definidas segundo as equações (18), (19) e (20), respectivamente.

$$
\begin{gathered}
S h=\frac{k_{s} \cdot d_{p}}{D_{L}} \\
S c=\frac{\mu_{L}}{D_{L}} \\
\operatorname{Re}_{p}^{*}=\frac{v_{s} \cdot d_{p}}{(1-\varepsilon) \cdot \mu_{L}}
\end{gathered}
$$

Em que:

$d_{p}=$ diâmetro da esfera equivalente

$D_{L}=$ difusividade do substrato na fase líquida

$\mu_{\mathrm{L}}=$ viscosidade do líquido

$\mathrm{v}_{\mathrm{s}}=$ velocidade superficial de líquido considerando a área da seção líquida do reator

$\varepsilon=$ porosidade do leito

Foi considerada a correlação apresentada por Welty et al. (1984), válida para sistemas líquido-sólido, a qual cobre reatores de leito fixo, para sistemas operando com $\mathrm{Re}_{\mathrm{p}}{ }^{*}$ entre 0,0016 e 55, com Sc entre 165 e 70600, $\varepsilon$ variando de 0,35 a 0,75 , e para baixas velocidades superficiais de líquido. Esta correlação é definida na equação (21).

$$
\mathrm{J}_{\mathrm{D}}^{*}=\frac{1.09 \cdot\left(\operatorname{Re}_{\mathrm{p}}^{*}\right)^{-1}}{\varepsilon}
$$

A resolução das equações supracitadas para a determinação de $k_{s}$ está descrita no item 5.6.1. 
A magnitude dos efeitos da resistência à transferência de massa intraparticular em relação às velocidades de reações bioquímicas foi avaliada por meio do módulo de Thiele observado $\left(\phi_{o b s}\right)$, definido segundo a equação (22). Este parâmetro adimensional permite avaliar a extensão do fenômeno difusivo em relação à velocidade reacional. Segundo Bringi e Dale (1990), se $\phi_{o b s} \geq 0,3$, a resistência interna à transferência de massa é significativa e a velocidade de difusão é a limitante do processo.

$$
\phi_{o b s}=\frac{r_{N_{o b s}} \cdot R_{p}^{2}}{9 \cdot D_{e} \cdot C_{N^{\prime}}}
$$

Em que:

$r_{N_{o b s}}=$ velocidade específica de consumo de nitrogênio observada $\left(\operatorname{mgN} \cdot \mathrm{L}^{-1} \cdot \mathrm{gSSV}^{-1} \cdot \mathrm{s}^{-1}\right)$;

$C_{N^{\prime}}=$ concentração específica de nitrogênio no meio líquido $\left(\mathrm{mgN} \cdot g \mathrm{gSV}^{-1} \cdot \mathrm{L}^{-1}\right)$;

Os valores de $r_{N_{o b s}}$ utilizados foram equivalentes à $r_{N^{\prime}}$ (equação 9) para $\mathrm{t}$ igual a zero em sua determinação, e tiveram a unidade de tempo em horas convertida para segundos.

Para análise mais completa da extensão dos fenômenos de transferência de massa no sistema reacional, foi determinado o fator de efetividade $(\eta)$ para cada modelo cinético ajustado. Este fator é definido fisicamente como a razão entre a velocidade de consumo de substrato observada e a velocidade obtida se não houvesse resistência à transferência de massa avaliada com o valor da concentração do substrato na fase líquida. O fator de efetividade apresenta valores variando entre 0 e 1 , e indica efetivamente como as resistências à transferência de massa estão influenciando negativamente a velocidade intrínseca de reação. Se os processos de transferência de massa são muito rápidos em relação às reações bioquímicas, $\eta$ é igual a 1. Entretanto, quando há influência de tais processos de transferência na velocidade global de reação, $\eta$ é menor que a unidade. 
A expressão do fator de efetividade foi obtida pela solução da equação diferencial resultante do balanço de massa para o substrato (nitrogênio) na biopartícula, o qual resultou na equação (23).

$$
\frac{d^{2} C_{N}}{d r^{2}}+\frac{2 \cdot d C_{N}}{r \cdot d r^{2}}=\frac{r_{N}}{D_{e}}
$$

Em que:

$C_{N}=$ concentração de nitrogênio em uma determinada posição radial $\mathrm{r}$

$r_{N}=$ velocidade de reação (consumo de nitrogênio)

Considerando resistência à transferência de massa na fase líquida e na fase sólida, a equação (23) foi resolvida com as condições de contorno apresentadas nas equações (24a) e $(24 b)$

$$
\begin{array}{ll}
r=0 ; & \frac{d C_{N}}{d r}=0 \\
r=R_{p} ; & {\left[-D_{e} \cdot\left(\frac{d C_{N}}{d r}\right)_{r=R_{p}}\right]=k_{s}\left(C_{N L}-C_{N i}\right)}
\end{array}
$$

Em que:

$C_{N L}=$ concentração de nitrogênio na fase líquida

$C_{N i}=$ concentração de nitrogênio na interface líquido sólido

Resolvendo a equação (24) para cinética de primeira ordem, o fator de efetividade foi expresso conforme a equação (25), em função do número de Biot e módulo de Thiele observado. 


$$
\eta=\frac{1}{\varphi}\left(\frac{1}{\operatorname{tgh}(3 \varphi)}-\frac{1}{3 \varphi}\right) \cdot\left\{\frac{\mathrm{Bi}}{3 \varphi / \operatorname{tgh}(3 \varphi)+\mathrm{Bi}-1}\right\}
$$

Os valores do fator de efetividade foram calculados apenas quando as resistências interna e externa à transferência de massa foram significativas.

\subsection{ENSAIOS MICROBIOLÓGICOS}

Os exames microbiológicos do lodo de inóculo e da biomassa aderida às espumas de poliuretano foram realizados por meio de microscópio óptico de contraste de fase disponível no Laboratório de Processos Biológicos. Uma câmera acoplada ao microscópio registrou as imagens por meio de um software que registrava a escala nas fotos. As amostras foram retiradas de um cubo de espuma de poliuretano de cada reator com auxílio de uma pinça e fixadas em lâminas com ágar. Tais exames foram realizados em ambas as fases da pesquisa.

\subsection{PROCEDIMENTO EXPERIMENTAL}

Nos próximos subitens será descrita, detalhadamente, a forma como foram conduzidos os experimentos em ambas as fases da pesquisa, englobando a montagem e operação dos reatores, assim como o procedimento para amostragens e realização de análises físicoquímicas. Para facilitar o entendimento, na Tabela 6 está apresentado, de forma geral, um cronograma semanal do procedimento experimental, contemplando o esquema de alimentação dos reatores e de realização das análises de monitoramento. 

ao tratamento de esgoto sanitário

Tabela 6 - Cronograma da alimentação e das análises de monitoramento realizados semanalmente.

\begin{tabular}{|c|c|c|c|c|c|c|c|}
\hline & Seg & Ter & Qua & Qui & Sex & Sáb & Dom \\
\hline Troca do meio líquido ${ }^{l}$ & & & & & & & \\
\hline Soluções injetadas ${ }^{2}$ & & & & & & & \\
\hline Análises de monitoramento ${ }^{3}$ & Início & Final & & Início & Final & & \\
\hline
\end{tabular}

${ }^{1}$ Correspondente ao efluente sintético nitrificado (fase 1) ou à mistura de efluentes (fase 2) sem adição de $\mathrm{KNO}_{3}$ ou $\mathrm{NaNO}_{2}, \mathrm{Na}_{2} \mathrm{~S}_{2} 9 \mathrm{H}_{2} \mathrm{O}$ e $\mathrm{NaHCO}_{3}$

${ }^{2}$ Soluções de $\mathrm{KNO}_{3}$ ou $\mathrm{NaNO}_{2}, \mathrm{Na}_{2} \mathrm{~S} .9 \mathrm{H}_{2} \mathrm{O}$ e $\mathrm{NaHCO}_{3}$

${ }^{3}$ Análises realizadas ao início (após troca do meio e injeção de soluções) e ao final de 24 horas

\subsubsection{Primeira fase - operação dos reatores}

Os frascos foram operados como reatores em batelada. A alimentação dos reatores era realizada de duas formas: por meio de soluções injetadas através do septo emborrachado localizado no topo dos frascos, quando os mesmos já estavam com atmosfera anóxica; e pelo descarte e fornecimento da água residuária, quando os frascos eram abertos. Isso ocorreu, pois os compostos $\mathrm{KNO}_{3}$ ou $\mathrm{NaNO}_{2}, \mathrm{Na}_{2} \mathrm{~S} .9 \mathrm{H}_{2} \mathrm{O}$ e $\mathrm{NaHCO}_{3}$, presentes na composição do efluente sintético utilizado, eram fornecidos separadamente na forma de soluções, por meio de seringas, conforme justificado no item 4.3.1. O fornecimento de tais soluções ocorria a cada ciclo de 24 horas, tempo suficiente para a desnitrificação completa do receptor de elétrons fornecido. A água residuária sintética, isenta destes compostos, os quais eram injetados separada e diariamente, era fornecida e descartada apenas duas vezes por semana, pois a troca contínua do meio líquido ocasionava perda de biomassa e a lavagem das espumas. Quando o líquido do interior dos frascos era trocado, realizava-se o fluxionamento com gás para garantir a atmosfera anóxica nos reatores. Inicialmente, nos primeiros 25 dias de operação, o fluxionamento foi realizado com gás hélio e a concentração de $\mathrm{NaHCO}_{3}$ injetada era baixa (300 mg. $\mathrm{L}^{-1}$ ); entretanto, com a aplicação freqüente de sulfeto, o pH do meio líquido no interior dos reatores se tornou muito alcalino, sendo desfavorável ao crescimento dos microrganismos de interesse. Desse modo, optou-se pelo fluxionamento com a mistura de 
gases $\mathrm{N}_{2} / \mathrm{CO}_{2}(30: 70 \%)$ e o aumento da concentração de $\mathrm{NaHCO}_{3}$ para $2000 \mathrm{mg} . \mathrm{L}^{-1}$, a fim de que o poder tamponante do sistema fosse aumentado.

Depois de inoculados, os frascos foram mantidos sob adaptação e, constatada a ocorrência de desnitrificação com consumo de sulfeto, iniciou-se o monitoramento dos parâmetros de interesse. As amostras foram coletadas logo após a troca do meio e introdução de substratos, e após 24 h, duas vezes por semana. As concentrações de sulfeto injetadas nos frascos foram gradualmente aumentadas conforme necessário, após a verificação de desnitrificação parcial e acúmulo de nitrito no sistema. Verificada a estabilidade operacional, com desnitrificação completa, foram realizados perfis temporais de concentração com duração de 24 h, para obtenção de parâmetros cinéticos dos reatores. Este procedimento foi realizado para nitrato e nitrito como receptores de elétrons, com exceção do fluxionamento com gás hélio e aplicação de baixa concentração de $\mathrm{NaHCO}_{3}$, que ocorreu somente com o uso do primeiro receptor.

O número de perfis realizados foi diferente para cada receptor de elétrons utilizado. Com o emprego de nitrato, realizaram-se dois perfis temporais de concentração dos compostos de interesse, sendo que, no intervalo entre eles, os reatores foram submetidos a aquecimento de $65^{\circ} \mathrm{C}$, por no máximo 5 horas, causado por falhas técnicas no painel de controle da câmara climatizada. Quando se utilizou nitrito como receptor, foi realizado apenas um perfil temporal de concentração dos compostos de interesse. Isso ocorreu, pois, após este perfil, houve aquecimento a $100{ }^{\circ} \mathrm{C}$ por cerca de 2 horas, também causado por problemas no painel de controle de temperatura da câmara, impossibilitando a continuação do experimento frente à destruição celular. 


\subsubsection{Segunda fase - operação dos reatores}

Os frascos foram operados de maneira semelhante à primeira fase. Foi aplicado apenas nitrato na forma de $\mathrm{KNO}_{3}$ como receptor de elétrons, o qual era fornecido diariamente, em intervalos de 24 horas, juntamente com as soluções de $\mathrm{Na}_{2} \mathrm{~S} .9 \mathrm{H}_{2} \mathrm{O}$ e $\mathrm{NaHCO}_{3}$. Tais soluções eram injetadas após o fechamento dos frascos com atmosfera anóxica. Da mesma forma que na primeira fase, a água residuária sem adição de $\mathrm{KNO}_{3}, \mathrm{Na}_{2} \mathrm{~S} .9 \mathrm{H}_{2} \mathrm{O}$ e $\mathrm{NaHCO}_{3}$, também era trocada apenas duas vezes por semana. Nesta etapa, o fluxionamento, realizado após a troca do meio líquido, já foi iniciado com a mistura de gases $\mathrm{N}_{2} / \mathrm{CO}_{2}$ e a concentração de $\mathrm{NaHCO}_{3}$ aplicada era de $2000 \mathrm{mg} \cdot \mathrm{L}^{-1}$.

Após a inoculação, os frascos foram mantidos sob adaptação em meio sintético nitrificado semelhante ao utilizado na primeira fase, sendo iniciado o monitoramento dos parâmetros de interesse depois de ser constatada a ocorrência de desnitrificação com consumo de sulfeto. $\mathrm{O}$ procedimento para coleta de amostras foi semelhante ao realizado na primeira fase, assim como a alimentação com sulfeto; entretanto, nesta fase, o aumento gradual das concentrações de sulfeto injetadas ocorreu em tempos diferentes para cada frasco, visto que a desnitrificação parcial com acúmulo de nitrito não ocorreu no mesmo período nos três frascos. Após cerca de 40 dias de adaptação, a alimentação passou a ser feita com uma mistura de efluente sintético nitrificado e efluente real de abatedouro de aves. A concentração de sulfeto aplicada inicialmente foi correspondente à relação estequiométrica relativamente à $\mathrm{N}^{-\mathrm{NO}_{3}}{ }^{-}$, não sendo verificada a necessidade de aumento da concentração deste doador de elétrons. Constatada a estabilidade operacional, com desnitrificação completa, foram realizados dois perfis temporais com duração de 24 h, para obtenção de parâmetros cinéticos dos reatores. Este procedimento foi realizado apenas para nitrato como receptor de elétrons. 


\subsubsection{Imobilização da biomassa}

O procedimento de imobilização da biomassa foi realizado no início das duas fases da pesquisa, e consistiu na colocação dos cubos de espuma de poliuretano em recipientes juntamente com o lodo previamente fragmentado em liquidificador, de forma que todas as espumas ficassem encobertas pelo lodo. Em seguida, as espumas e o lodo foram homogeneizados com auxílio de um bastão de vidro e permaneceram em contato por período de 24 horas à temperatura ambiente, em recipientes cobertos com filme plástico. Decorrido este período, as matrizes de espuma foram transferidas para o interior dos frascos com o uso de pinça, sendo colocadas 100 espumas em cada frasco. O excesso de lodo foi eliminado durante o período de adaptação dos reatores, por meio da troca do meio líquido contido no interior dos frascos, que proporcionava o arraste do lodo não aderido às espumas.

\subsubsection{Ensaios complementares - testes abióticos}

Os ensaios abióticos foram realizados para certificar que as alterações dos compostos de interesse, no interior dos frascos, ocorreram, principalmente, devido à ação dos microorganismos presente no lodo inoculado. As condições utilizadas para estes testes foram semelhantes aos ensaios biológicos em estabilidade; entretanto, nenhum lodo de inóculo foi adicionado, e os frascos contendo os meios líquidos foram previamente autoclavados por 40 minutos a $121^{\circ} \mathrm{C}$ e 1 atm para eliminar qualquer microrganismo presente. Ensaios abióticos sem adição de cubos de espuma de poliuretano também foram realizados com a finalidade de avaliar a influência desta sobre o processo. Nos testes abióticos relacionados com a segunda fase, além de serem utilizadas as condições semelhantes aos ensaios biológicos $(\mathrm{N} / \mathrm{S}=1,6)$, foram aplicadas maiores concentrações de soluções de sulfeto e de nitrato, na relação N/S equivalente a 0,8 (excesso de sulfeto dissolvido). Todas as condições aplicadas em ambas as 
fases, referentes às concentrações teóricas de sulfeto dissolvido total e nitrato, estão apresentadas na Tabela 7.

Tabela 7 - Concentrações teóricas das soluções de sulfeto e de nitrato aplicadas aos ensaios abióticos, com as respectivas relações N/S, em ambas as fases.

\begin{tabular}{|c|c|c|c|c|}
\hline & $\begin{array}{l}\text { Adição de } \\
\text { espumas }\end{array}$ & Relação N/S & $\mathrm{mgN}^{-\mathrm{NO}_{3}}{ }^{-} \cdot \mathrm{L}^{-1}$ & $\operatorname{mgSDT} . L^{-1}$ \\
\hline \multirow{2}{*}{ Fase 1} & Sim & 0,8 & 20 & 60 \\
\hline & Não & 0,8 & 20 & 60 \\
\hline \multirow{3}{*}{ Fase 2} & Sim & 1,6 & 10 & 15 \\
\hline & Sim & 0,8 & 20 & 60 \\
\hline & Não & 0,8 & 20 & 60 \\
\hline
\end{tabular}

\subsubsection{Amostragem e análises físico-químicas}

O monitoramento dos reatores foi realizado por meio de análises de amostras coletadas ao início e ao final de 24 horas, sendo realizadas em média duas vezes por semana. As amostras eram coletadas com o uso de seringas, através do septo emborrachado na parte superior dos reatores. As análises de sulfeto, sulfato e medições de $\mathrm{pH}$ eram realizadas logo após a coleta das amostras. Para as análises de nitrito e nitrato as amostras eram congeladas por até uma semana antes de serem utilizadas. As amostras para determinação de nitrogênio amoniacal eram acidificadas com uma gota $(8 \mu \mathrm{L})$ de ácido sulfúrico concentrado e também refrigeradas por até uma semana. 


\section{RESULTADOS E DISCUSSÃO}

\subsection{CARACTERÍSTICAS DO LODO DE INÓCULO}

Para a caracterização do lodo utilizado foram realizados, inicialmente, exames microscópicos com a finalidade de avaliar a diversidade microbiana existente. O lodo bruto se apresentava na forma granular, possuindo boa qualidade com relação à diversidade microbiana. Entretanto, a visualização da biomassa por meio das técnicas de microscopia ficou prejudicada em função da grande quantidade de material extracelular presente no lodo.

Os exames microscópicos revelaram a predominância de bacilos, cocos e filamentos. Também foram observados microrganismos com morfologia semelhante à Methanosaeta sp.. Algumas das morfologias encontradas estão apresentadas na Figura 4.
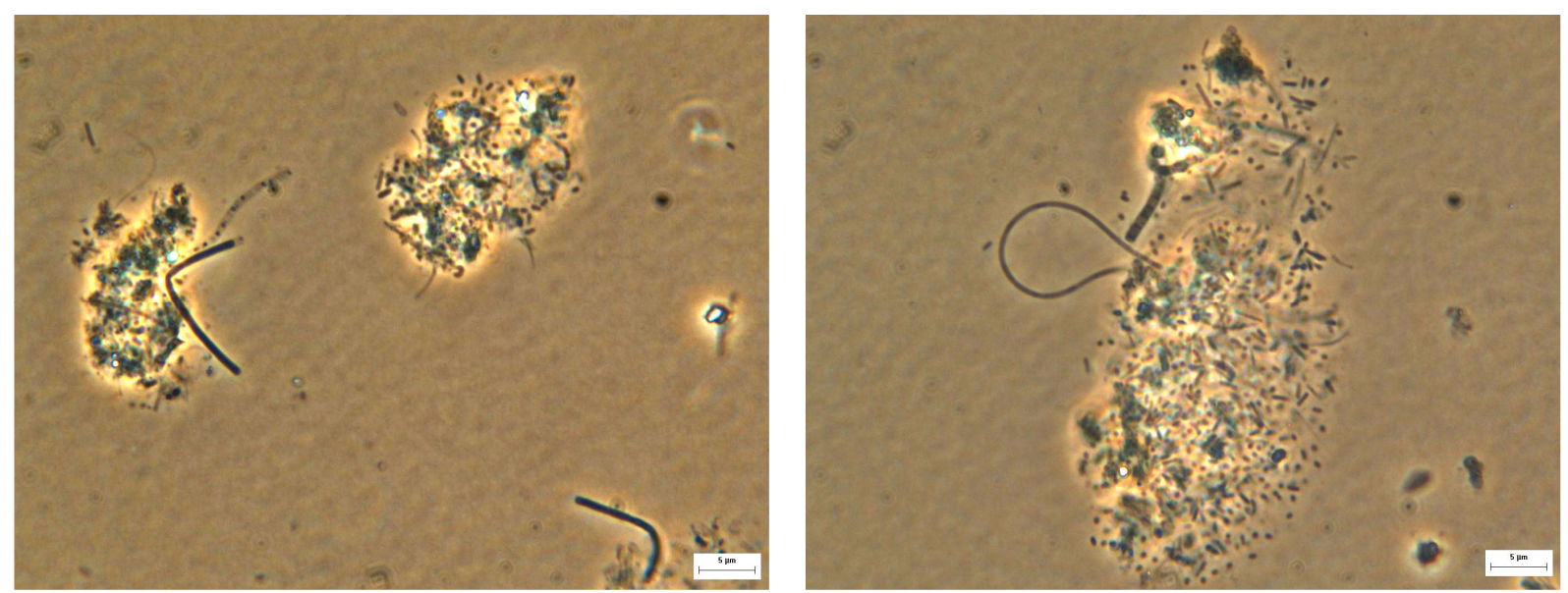

Figura 4 - Morfologias observadas sob microscopia óptica de contraste de fase do lodo de inóculo: presença de filamentos, bacilos, cocos e filamentos semelhantes à Methanosaeta sp.

\subsection{ANÁLISES DE MONITORAMENTO - PRIMEIRA FASE}

Neste item são apresentados os dados experimentais da primeira fase, monitorados durante toda a operação dos reatores, contemplando os valores de concentração dos 
compostos analisados e a discussão dos resultados encontrados. Tais resultados estão subdivididos a seguir em dois itens, de acordo com os receptores de elétrons aplicados nesta fase: nitrato e nitrito.

\subsubsection{Nitrato como receptor de elétrons}

Os reatores foram operados por 146 dias. No início dos ensaios, utilizou-se baixa concentração de sulfeto $(\mathrm{N} / \mathrm{S}=4,8)$ e baixa concentração de $\mathrm{NaHCO}_{3}\left(300 \mathrm{mg} \cdot \mathrm{L}^{-1}\right)$ conforme procedimento realizado por Garbossa (2006). Constatada a necessidade de maior alcalinidade para o meio, aumentou-se a concentração de $\mathrm{NaHCO}_{3}$ para $2000 \mathrm{mg} . \mathrm{L}^{-1}$, segundo proposto por Beristain-Cardoso et al. (2006). Além disso, o fluxionamento passou a ser feito com a mistura de gases $\mathrm{N}_{2} / \mathrm{CO}_{2}$ ao invés de hélio. Isso possibilitou a manutenção dos valores de $\mathrm{pH}$ entre 7,0 e 7,5, ideais para o crescimento dos microrganismos de interesse, e, conseqüentemente, foi possível utilizar concentrações de sulfeto superiores, correspondentes a relações molares N/S de 1,6, 1,2 e 0,8, sendo que a relação intermediária N/S de 1,2 foi mantida apenas provisoriamente.

Na Figura 5 está representado o comportamento do $\mathrm{pH}$ médio dos reatores durante o período de operação, na qual podem ser observados valores mais altos de pH no início dos experimentos $(\mathrm{N} / \mathrm{S}=4,8)$ e a manutenção de valores próximos à neutralidade nas outras condições experimentais (N/S de 1,6, 1,2 e 0,8).

A partir das análises de monitoramento, também foram obtidos os valores médios de concentração das formas de enxofre $\left(\mathrm{SDT}, \mathrm{S}_{-} \mathrm{SO}_{4}{ }^{-2}\right)$ e das formas de nitrogênio $\left(\mathrm{N}_{-} \mathrm{NO}_{3}^{-}, \mathrm{N}-\right.$ $\mathrm{NO}_{2}{ }^{-}, \mathrm{N}-\mathrm{NH}_{4}^{+}{ }^{+}$. 


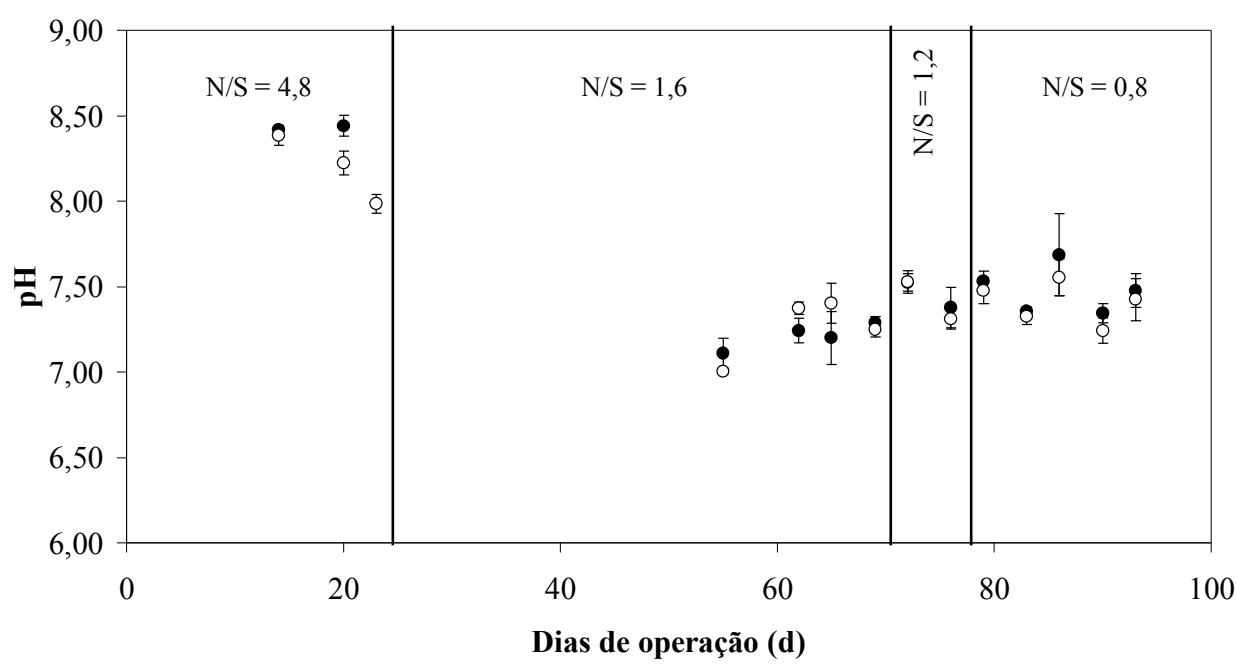

Figura 5 - Valores médios dos dados de monitoramento do pH: (•) início e (०) final do ciclo; experimento utilizando nitrato como receptor de elétrons

As concentrações médias de sulfato detectadas no início dos ciclos (Figura 6) provavelmente foram devidas à operação em batelada, já que o meio líquido não continha sulfato. Dessa forma, o sulfato formado ao final de um ciclo era acumulado no início de outro. Além disso, parte do meio líquido era absorvida pelas espumas, não sendo totalmente descartado durante as trocas do meio.

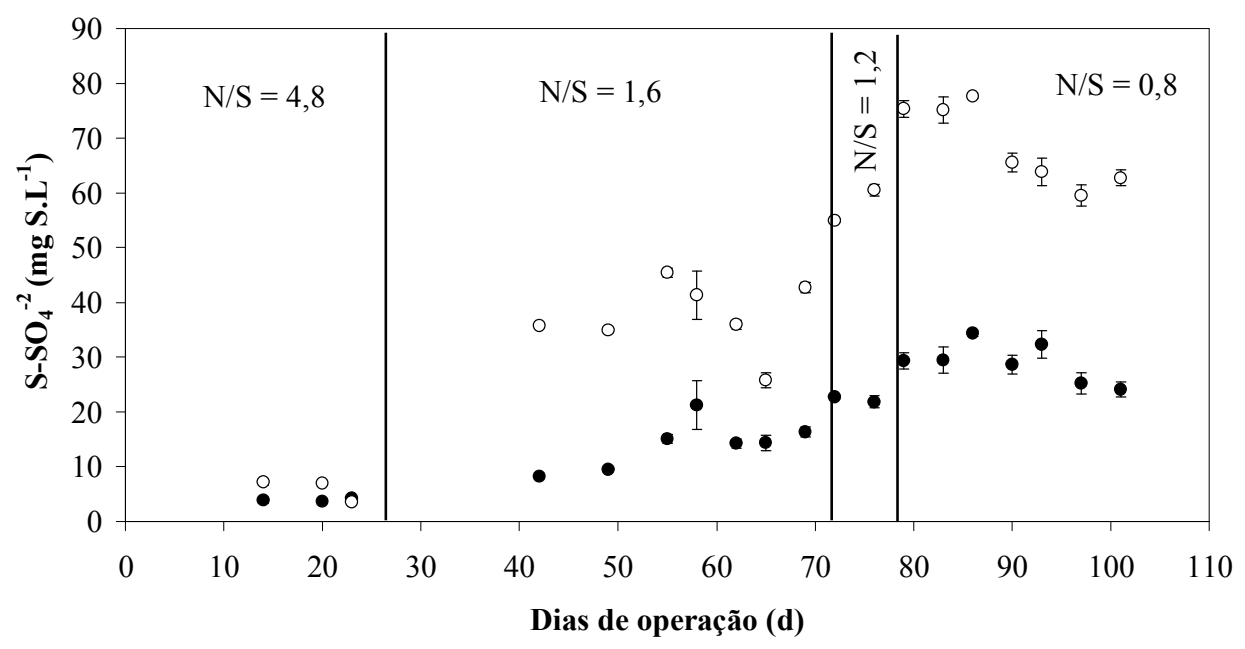

Figura 6 - Valores médios dos dados de monitoramento de sulfato: $(\bullet)$ início e (०) final do ciclo; experimento utilizando nitrato como receptor de elétrons

Na Figura 7, observa-se que as concentrações de sulfeto medidas na fase inicial de cada ciclo, foram inferiores às concentrações teóricas adicionadas, em todas as condições. 
Este fato pode ser justificado pelo atraso na coleta de amostras após a adição da solução de sulfeto. Durante este tempo, parte do sulfeto solúvel adicionado ao interior dos reatores provavelmente foi perdida para o biogás presente no headspace, a fim de que o equilíbrio químico entre as formas de sulfeto solúvel e gasosa, de acordo com a Lei de Henry, fosse atingido. Existe, também, a possibilidade de ter ocorrido adsorção na biomassa, ou, ainda, a formação de enxofre elementar e polissulfetos.

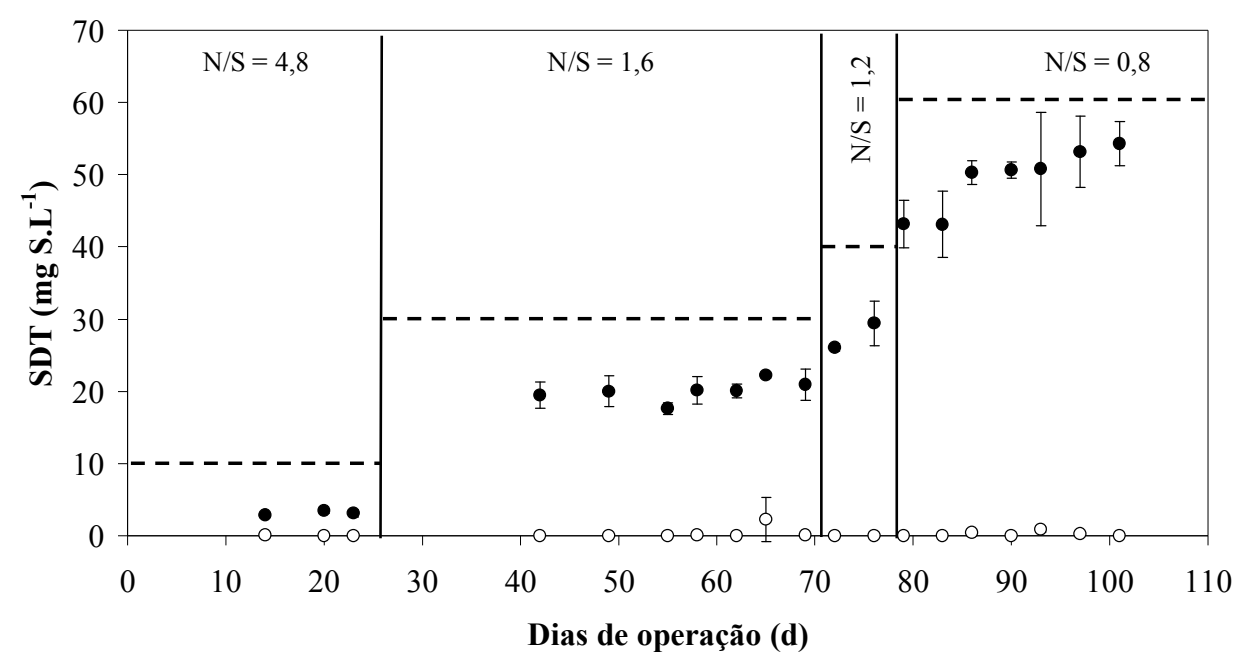

Figura 7 - Valores médios dos dados de monitoramento de sulfeto: $(\bullet)$ início e (०) final do ciclo; ---concentração teórica adicionada de sulfeto; experimento utilizando nitrato como receptor de elétrons

Observa-se que o sulfeto adicionado foi consumido completamente em todas as condições e em todos os reatores. Isto comprova que, para todas as relações N/S estudadas, a concentração excessiva ou insuficiente em relação à estequiometria $(\mathrm{N} / \mathrm{S}=1,6)$ não provocou influência no consumo do mesmo. Entretanto, as diferentes relações N/S influenciaram a formação de produtos intermediários e do produto final (sulfato) da oxidação de sulfeto por meio da desnitrificação autotrófica. Este fato pode ser verificado pela observação das concentrações de sulfato formadas, (Figura 8). Para relação estequiométrica N/S de 1,6, a variação da concentração de sulfato aproximou-se do valor teórico adicionado de sulfeto, fechando, com pequena variação, o balanço de massa. Quando o sulfeto foi adicionado em 
excesso $(\mathrm{N} / \mathrm{S}=0,8)$, a variação da concentração de sulfato foi bem inferior à esperada, o que sugere a formação de compostos intermediários de enxofre, como enxofre elementar $\left(\mathrm{S}^{0}\right)$. Esta hipótese foi reforçada pela alteração das características visuais do líquido, o qual se tornava esbranquiçado e amarelado no decorrer dos ciclos, indicativo da presença de enxofre elementar. Dessa forma, concentrações excessivas de sulfeto, em relação ao nitrato, provavelmente conduziram à oxidação parcial deste doador de elétrons, havendo formação de produtos intermediários como enxofre elementar e polissulfetos.

Esta última observação também foi constatada por Beristain-Cardoso et al. (2006), os quais avaliaram a influência de diferentes relações N/S sobre a desnitrificação autotrófica. Krishnakumar e Manilal (1999) verificaram o mesmo comportamento sob condições de excesso de sulfeto em reatores desnitrificantes em batelada, visualizando a coloração esbranquiçada da solução devido ao possível acúmulo de enxofre elementar como intermediário da oxidação de sulfeto. Além destas observações reportadas na literatura, na presente pesquisa foi observado o recobrimento das espumas por camadas esbranquiçadas ao longo dos ciclos.

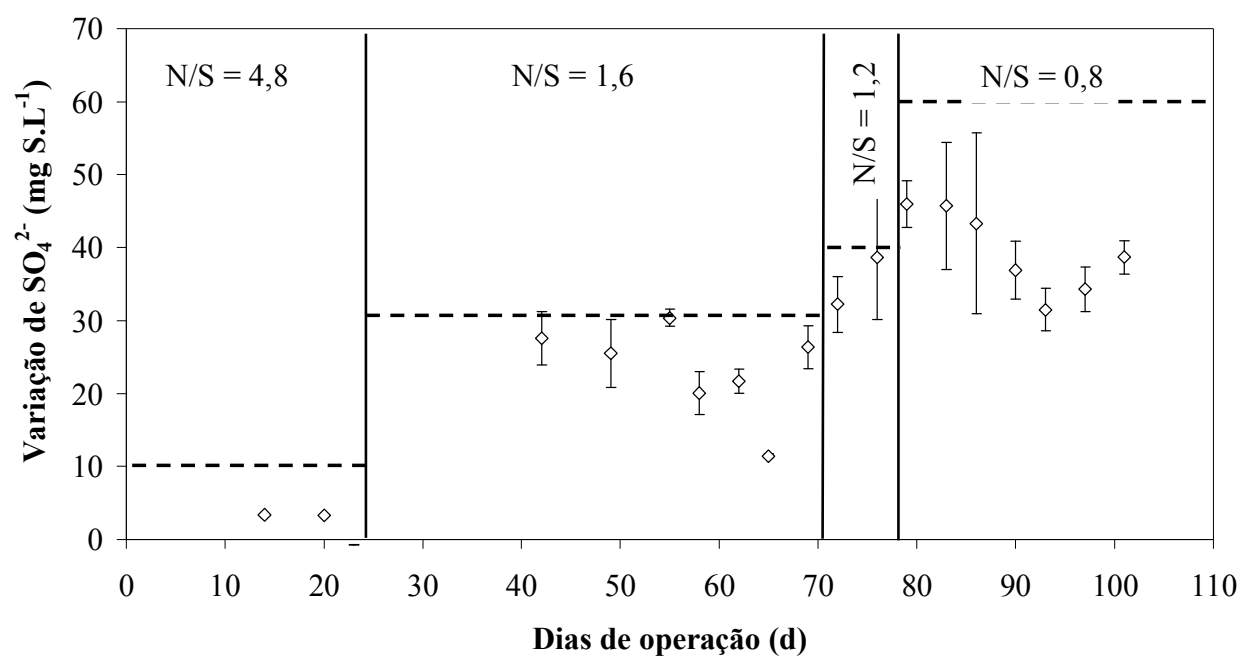

Figura 8 - Valores médios da variação de sulfato: ---- concentração teórica resultante de sulfato; experimento utilizando nitrato como receptor de elétrons 
Segundo Kleerebezem e Mendez (2002), o acúmulo de enxofre elementar em reatores de leito fixo pode causar o decréscimo de eficiência na retenção da biomassa e diminuir a capacidade de tratamento do reator, mas salientam a necessidade de maiores pesquisas para esclarecer questões relacionadas aos produtos formados pela oxidação de sulfeto via desnitrificação autotrófica. Além disso, diversos autores relatam que o enxofre elementar é o doador de elétrons mais ineficiente para a desnitrificação entre os compostos de enxofre (Campos et al. 2008; Beristain-Cardoso et al, 2006; Koenig e Liu, 2001). Todavia, existem relatos na literatura a respeito da desnitrificação com aplicação de enxofre elementar, especificamente, realizada com sucesso (Soares, 2002; Gommers e Kuen, 1988). Tal diversidade de resultados pode ser atribuída às diferentes fontes de inóculo utilizadas e à forma de adaptação do lodo inoculado, proporcionando a seleção dos microrganismos de interesse.

A remoção completa de nitrato foi detectada em todos os ensaios em que a concentração de sulfeto solúvel foi equivalente ou superior à estequiométrica, conforme a Figura 9. Quando a concentração de sulfeto foi limitante (N/S =4,8), observou-se o consumo incompleto de nitrato. No período em que foi aplicado sulfeto em concentração correspondente a relação N/S estequiométrica $(1,6)$ relativamente a nitrato, após 15 dias de operação foi verificada instabilidade no comportamento das triplicatas. A partir de então, a desnitrificação passou a ser incompleta, sendo detectada pelo acúmulo de nitrito (Figura 10). Em vista da possibilidade de insuficiência da concentração de sulfeto, optou-se por dobrá-la, resultando na relação $\mathrm{N} / \mathrm{S}$ de 0,8 . O aumento da concentração, porém, foi gradual, adotandose uma condição intermediária correspondente à relação N/S de 1,2, mantida por uma semana. Neste período transitório, a desnitrificação incompleta com acúmulo de nitrito permaneceu. Após a aplicação de N/S de 0,8 , a desnitrificação passou a ser completa novamente, sem 
acúmulo de nitrito ao final do ciclo, e os reatores permaneceram com este comportamento até o final dos ensaios que utilizaram nitrato como receptor.

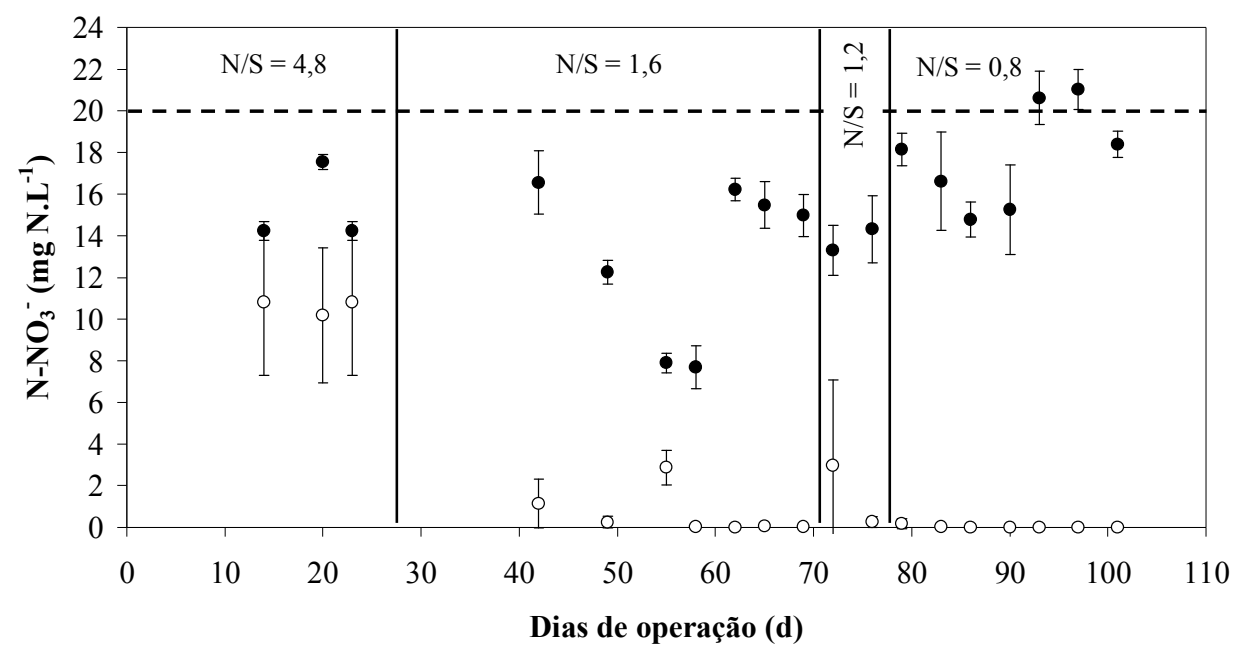

Figura 9 - Valores médios dos dados de monitoramento de nitrato: $(\bullet)$ início e (०) final do ciclo; ---concentração teórica adicionada de nitrato; experimento utilizando nitrato como receptor de elétrons

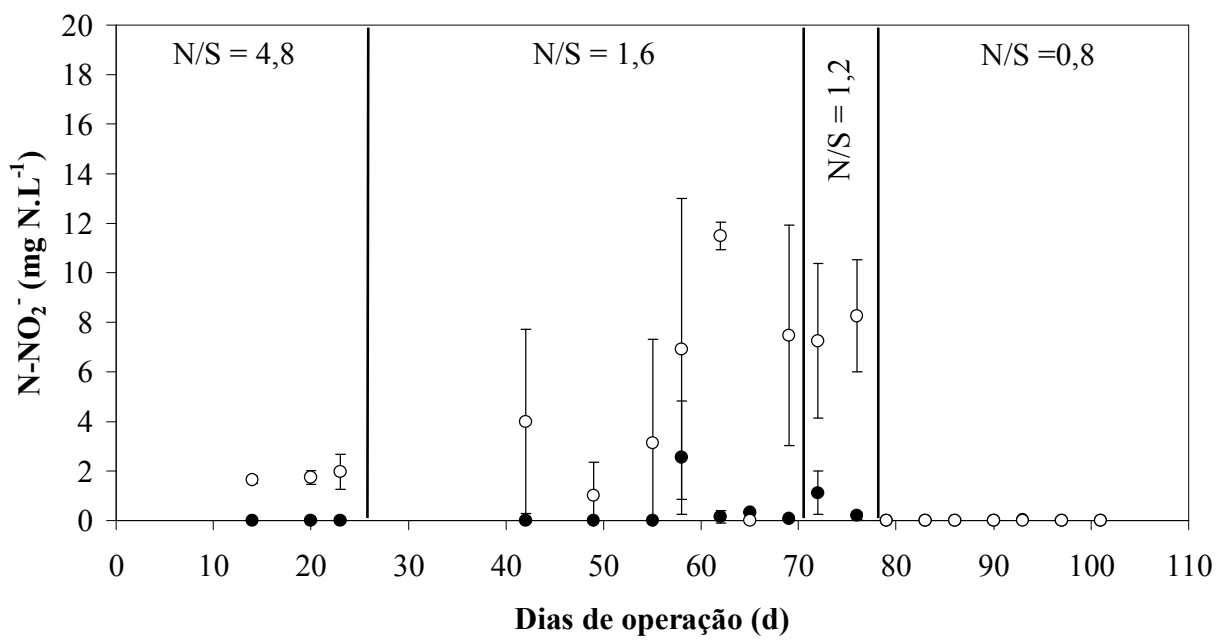

Figura 10 - Valores médios dos dados de monitoramento de nitrito: $(\bullet)$ início e (०) final do ciclo; experimento utilizando nitrato como receptor de elétrons

A desnitrificação incompleta com acúmulo de nitrito ocorreu em função da insuficiência de elétrons doados, na oxidação de sulfeto, para a redução completa de nitrato a nitrogênio gasoso. Este fato está diretamente relacionado com a formação de enxofre elementar por meio da oxidação incompleta de sulfeto, visto que para esta reação são 
liberados menos elétrons em relação à reação de oxidação completa de sulfeto a sulfato, como pode ser observado pelas reações relativas aos doadores de elétrons propostas por Kleerebezem e Mendez (2002), apresentadas nas equações 26 e 27.

$$
\begin{gathered}
\mathrm{HS}^{-} \rightarrow \mathrm{S}+\mathrm{H}^{+}+2 e^{-} \\
\mathrm{HS}^{-}+4 \mathrm{H}_{2} \mathrm{O} \rightarrow \mathrm{SO}_{4}^{2-}+9 \mathrm{H}^{+}+8 e^{-}
\end{gathered}
$$

De acordo com Krinshnakumar e Manilal (1999), a possível reação de oxidação anóxica de sulfeto e redução incompleta de nitrato pode ser descrita como apresentado na equação 28.

$$
\mathrm{NO}_{3}^{-}+\mathrm{HS}^{-} \rightarrow \mathrm{S}^{0}+\mathrm{NO}_{2}^{-}+\mathrm{OH}^{-}
$$

Observa-se, pela reação anterior, que a formação de enxofre elementar por meio da desnitrificação incompleta pode causar aumento do $\mathrm{pH}$ em função da geração de íons $\mathrm{OH}^{-}$. $\mathrm{Na}$ última condição testada neste experimento $(\mathrm{N} / \mathrm{S}=0,8)$, na qual se presumiu maior formação de produtos intermediários da oxidação de sulfeto, foram detectados alguns valores de $\mathrm{pH}$ ligeiramente maiores que os medidos na segunda condição $(\mathrm{N} / \mathrm{S}=1,6)$. De modo geral, observou-se que a elevação do $\mathrm{pH}$ foi de 7,2 a 7,5. Nos ensaios realizados pelos autores supracitados, também foi constatado o aumento do $\mathrm{pH}$, de 7,5 a 8,0.

O comportamento de nitrogênio amoniacal também foi acompanhado ao longo dos ensaios, para verificação da ocorrência de redução dissimilativa de nitrato a amônia (RDNA). Os resultados obtidos indicaram que não houve geração significativa de nitrogênio amoniacal em nenhum dos reatores para todas as relações N/S, conforme observado na Figura 11. 


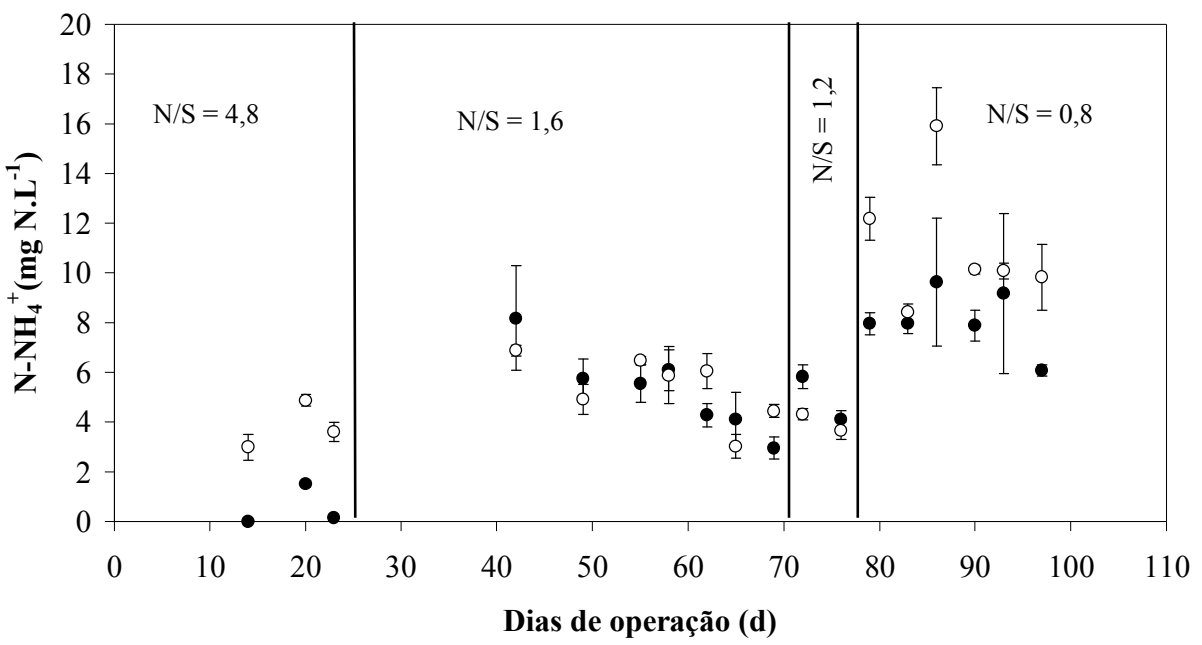

Figura 11 - Valores médios dos dados de monitoramento de nitrogênio amoniacal: $(\bullet)$ início e (०) final do ciclo; experimento utilizando nitrato como receptor de elétrons

\subsubsection{Nitrito como receptor de elétrons}

Após os ensaios com nitrato, procedeu-se à mudança dos receptores de elétrons, adotando-se nitrito para este fim. Nesta nova etapa os reatores foram operados por aproximadamente 30 dias, e foram aplicadas duas relações N/S, correspondentes a 2,7 (estequiométrica) e 1,4. Da mesma maneira que na etapa anterior, foi realizado monitoramento dos parâmetros de interesse ao longo da operação.

Os valores médios de $\mathrm{pH}$ ficaram em torno de $\mathrm{pH}$ neutro (Figura 12), assim como ocorreu nos ensaios com aplicação de nitrato após o aumento da concentração de $\mathrm{NaHCO}_{3} \mathrm{e}$ fluxionamento com a mistura de gases $\mathrm{N}_{2} / \mathrm{CO}_{2}$.

Os compostos de enxofre apresentaram comportamento semelhante à etapa anterior, com consumo total de sulfeto nas duas relações $\mathrm{N} / \mathrm{S}$, porém com oxidação incompleta do mesmo, principalmente na relação N/S de 1,4. 


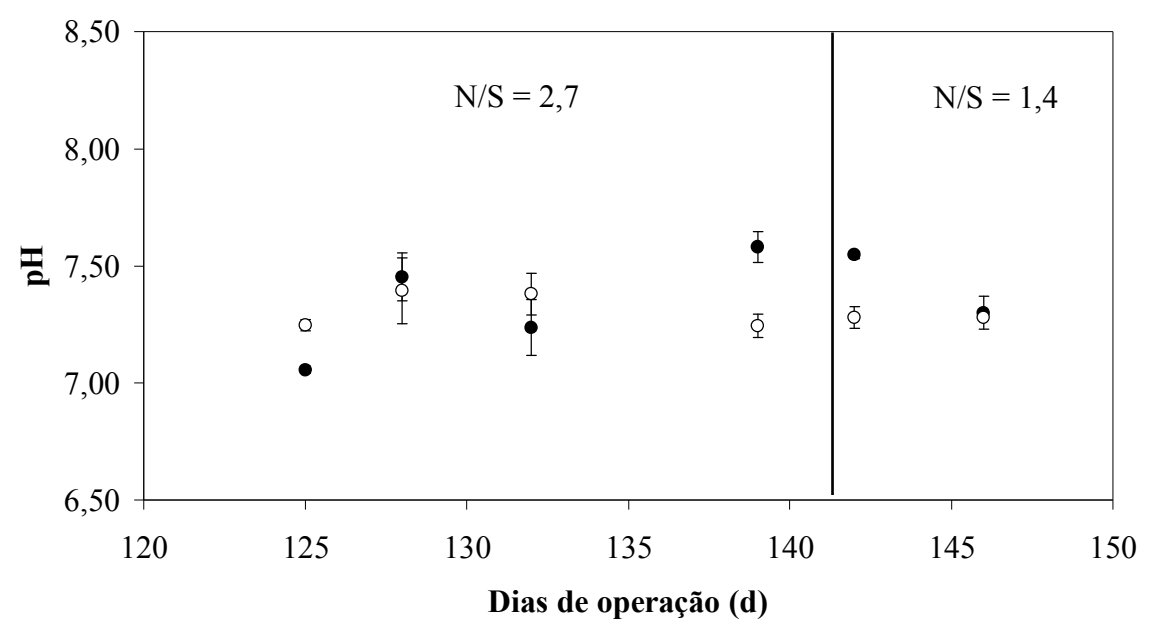

Figura 12 - Valores médios dos dados de monitoramento do pH: (•) início e (०) final do ciclo; experimento utilizando nitrito como receptor de elétrons

Na Figura 13 nota-se o decaimento das concentrações de sulfato no início e final dos ciclos ao longo do tempo, na primeira condição testada $(\mathrm{N} / \mathrm{S}=2,7)$, fato que sinaliza para a formação de compostos intermediários de enxofre a partir da oxidação incompleta do sulfeto aplicado. Este fato é mais bem visualizado na Figura 14, na qual são apresentados os valores médios da variação da concentração de sulfato. A formação de sulfato permaneceu praticamente constante, mesmo com o aumento da concentração de sulfeto $(\mathrm{N} / \mathrm{S}=1,4)$. Nesta condição, a oxidação incompleta de sulfeto ficou mais acentuada, como pode ser observada pela maior defasagem dos valores experimentais com relação ao valor teórico. A hipótese de formação de compostos intermediários de enxofre foi novamente reforçada pela alteração das características visuais do líquido, o qual se tornava esbranquiçado e amarelado no decorrer dos ciclos, assim como ocorreu no ensaio anterior, indicando a presença de enxofre elementar. Neste caso, também ocorreu o recobrimento dos cubos de espuma por camadas esbranquiçadas ao longo dos ciclos. 


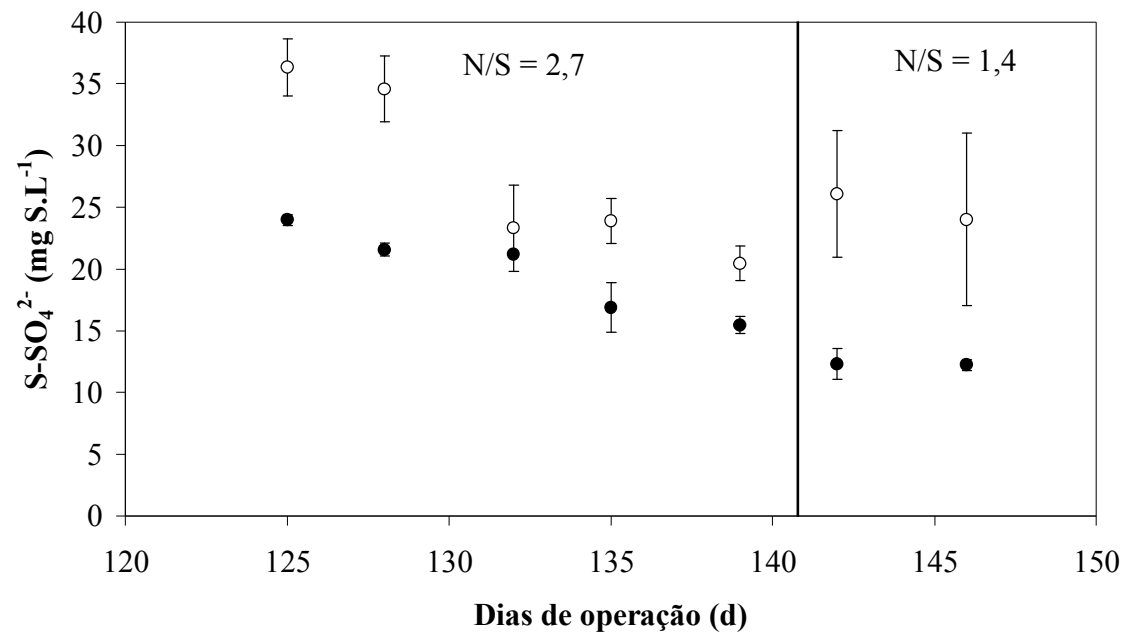

Figura 13 - Valores médios dos dados de monitoramento de sulfato: $(\bullet)$ início e $(\circ)$ final do ciclo; experimento utilizando nitrito como receptor de elétrons

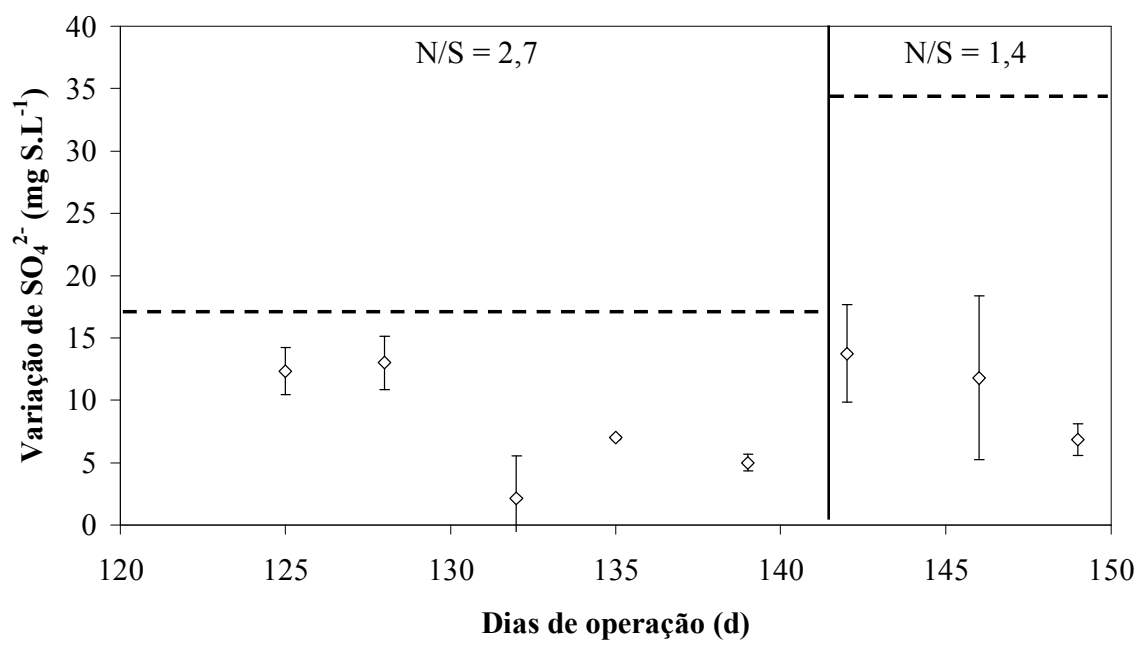

Figura 14 - Valores médios da variação de sulfato: ---- concentração teórica resultante de sulfato; experimento utilizando nitrito como receptor de elétrons

As concentrações de sulfeto adicionadas foram totalmente consumidas em todos os reatores e nas duas condições testadas (Figura 15). Novamente, isto comprova que, para as relações N/S estudadas, a concentração excessiva de sulfeto ou equivalente a estequiométrica em relação ao nitrito $(\mathrm{N} / \mathrm{S}=2,7)$ não provocou influência no consumo do mesmo; mas as diferentes relações N/S influenciaram a formação de produtos formados a partir da oxidação parcial ou total de sulfeto por meio da desnitrificação autotrófica. 


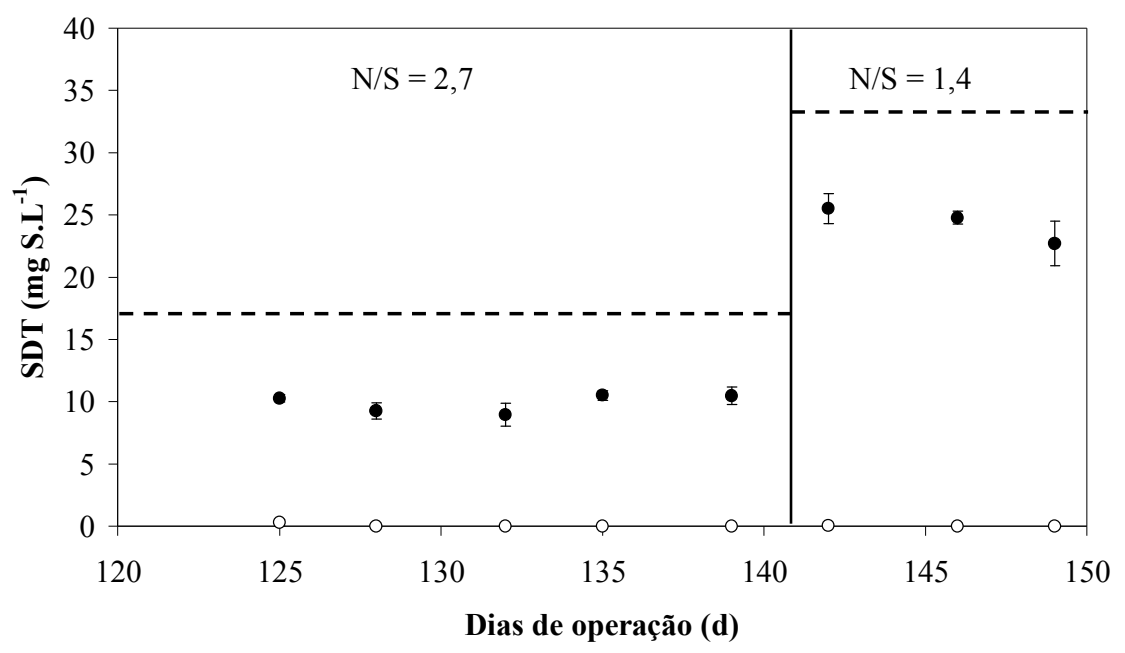

Figura 15 - Valores médios dos dados de monitoramento de sulfeto: $(\bullet)$ início e (०) final do ciclo; --concentração teórica adicionada de sulfeto; experimento utilizando nitrito como receptor de elétrons

Com relação aos compostos oxidados de nitrogênio, não foi detectada em nenhum momento a presença de nitrato em níveis significativos (Figura 16), e o nitrito passou a não ser consumido totalmente após cerca de 10 dias de operação com a relação N/S estequiométrica (Figura 17). Isto mostra que a concentração de sulfeto foi insuficiente, similarmente ao ocorrido nos ensaios com aplicação de nitrato, e, portanto, procedeu-se também à elevação da concentração de sulfeto para o dobro da necessária estequiometricamente $(\mathrm{N} / \mathrm{S}=1,4)$. A partir desta nova condição, a desnitrificação com nitrito passou a ser completa.

Os níveis de nitrogênio amoniacal mantiveram-se estáveis quanto à geração ao longo de um ciclo, indicando que a RDNA não ocorreu (Figura 18). 


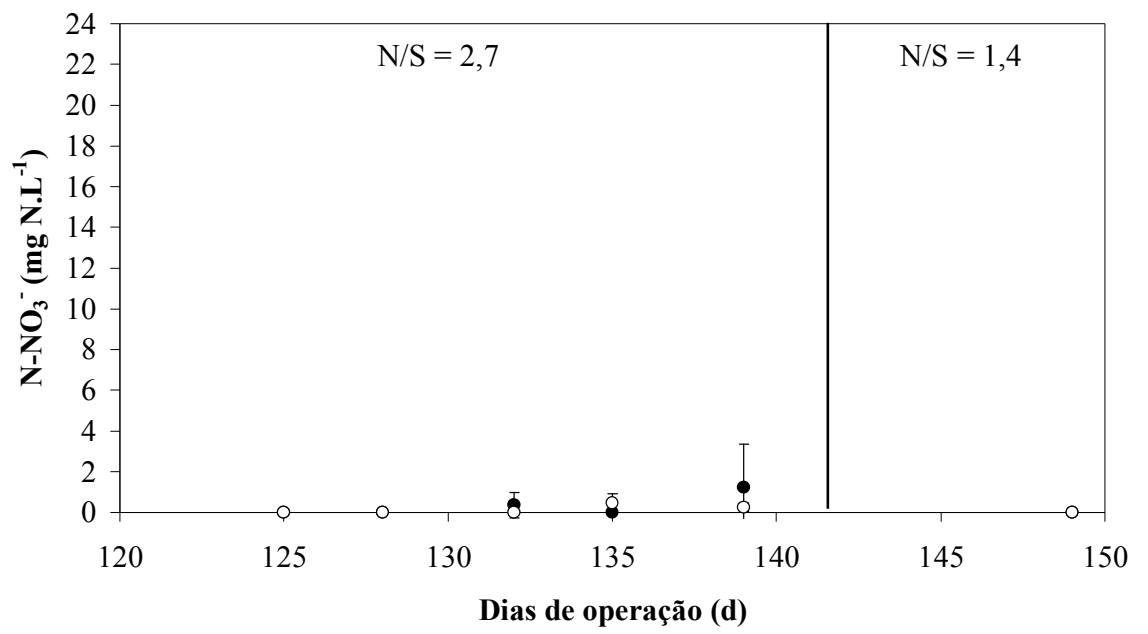

Figura 16 - Valores médios dos dados de monitoramento de nitrato: (•) início e (०) final do ciclo; experimento utilizando nitrito como receptor de elétrons

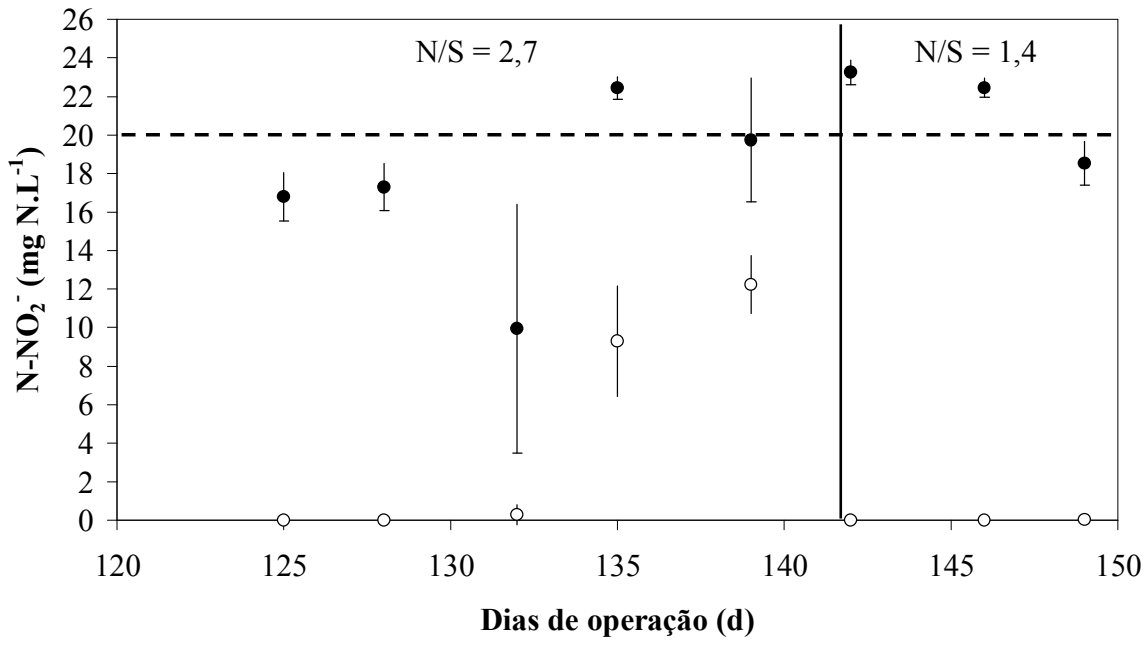

Figura 17 - Valores médios dos dados de monitoramento de nitrito: (•) início e (○) final do ciclo; ---concentração teórica adicionada de nitrito;experimento utilizando nitrito como receptor de elétrons

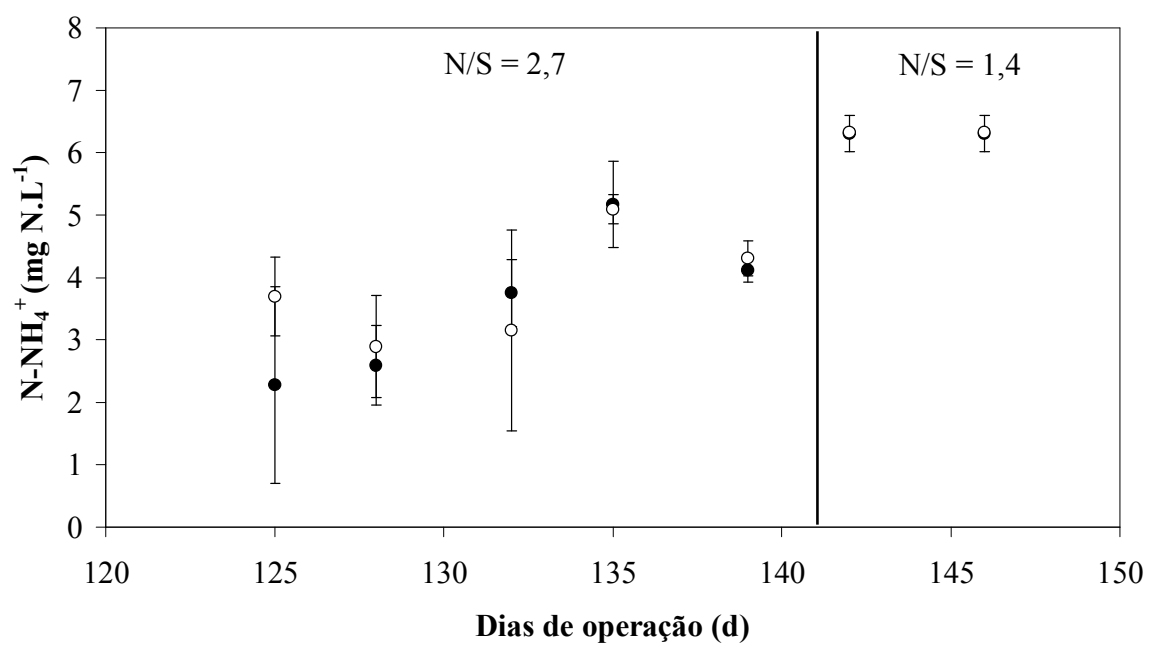

Figura 18 - Valores médios dos dados de monitoramento de nitrogênio amoniacal: $(\bullet)$ início e (०) final do ciclo; experimento utilizando nitrito como receptor de elétrons 


\subsection{ANÁLISES DE MONITORAMENTO - SEGUNDA FASE}

Neste item são apresentados os dados de monitoramento dos experimentos realizados na segunda fase do projeto, sendo descritos e discutidos todos os resultados obtidos.

$\mathrm{Na}$ segunda etapa, foram iniciados novos experimentos, procedendo-se de forma semelhante à fase anterior: as espumas foram inoculadas e a adaptação dos frascos ocorreu com água residuária sintética nitrificada. A concentração de sulfeto aplicada inicialmente foi equivalente à estequiométrica com relação à concentração de nitrato utilizada $(\mathrm{N} / \mathrm{S}=1,6)$. Da mesma forma que na primeira fase, durante o período de adaptação, foi observada desnitrificação parcial com acúmulo de nitrito, sendo necessário aumentar a concentração de sulfeto injetada para o dobro da relação estequiométrica $(\mathrm{N} / \mathrm{S}=0,8)$. A necessidade de aplicar maior concentração de sulfeto ocorreu em tempos diferentes para cada frasco, fato que proporcionou alto desvio-padrão nas médias das triplicatas ao final do período de adaptação. Terminado este período, os frascos foram submetidos à nova condição, na qual a alimentação passou a ser feita com uma mistura de efluente sintético nitrificado e efluente real de abatedouro de aves diluído. Nesta condição, a concentração de sulfeto aplicada foi correspondente à relação estequiométrica relativamente à $\mathrm{N}_{-1 \mathrm{NO}_{3}}{ }^{-}(\mathrm{N} / \mathrm{S}=1,6)$.

Os dados de monitoramento das formas de enxofre (SDT, $\mathrm{S}-\mathrm{SO}_{4}{ }^{-2}$ ), das formas de nitrogênio $\left(\mathrm{N}_{-} \mathrm{NO}_{3}{ }^{-}, \mathrm{N}-\mathrm{NO}_{2}{ }^{-}, \mathrm{N}-\mathrm{NH}_{4}{ }^{+}\right)$e do $\mathrm{pH}$ contemplaram o período de adaptação e da nova condição.

Os valores de $\mathrm{pH}$ durante o período de adaptação permaneceram em torno de 7,0-7,5, conforme ilustrado na Figura 19. Após a adição do efluente de reator anaeróbio tratando água residuária de abatedouro de aves, utilizado na alimentação dos reatores, observou-se a queda gradual do $\mathrm{pH}$ para valores inferiores a 7. Frente à continuidade desta queda de $\mathrm{pH}$, optou-se pelo aumento da concentração de $\mathrm{NaHCO}_{3}$ para $2000 \mathrm{mg} \cdot \mathrm{L}^{-1}$ novamente, visto que a concentração deste foi reduzida à metade em função da mistura $(50 \%-50 \%)$ das águas 
residuárias utilizadas na nova alimentação. A partir deste dia, correspondente a 50 dias de operação, o pH retornou a valores em torno de 7,2.

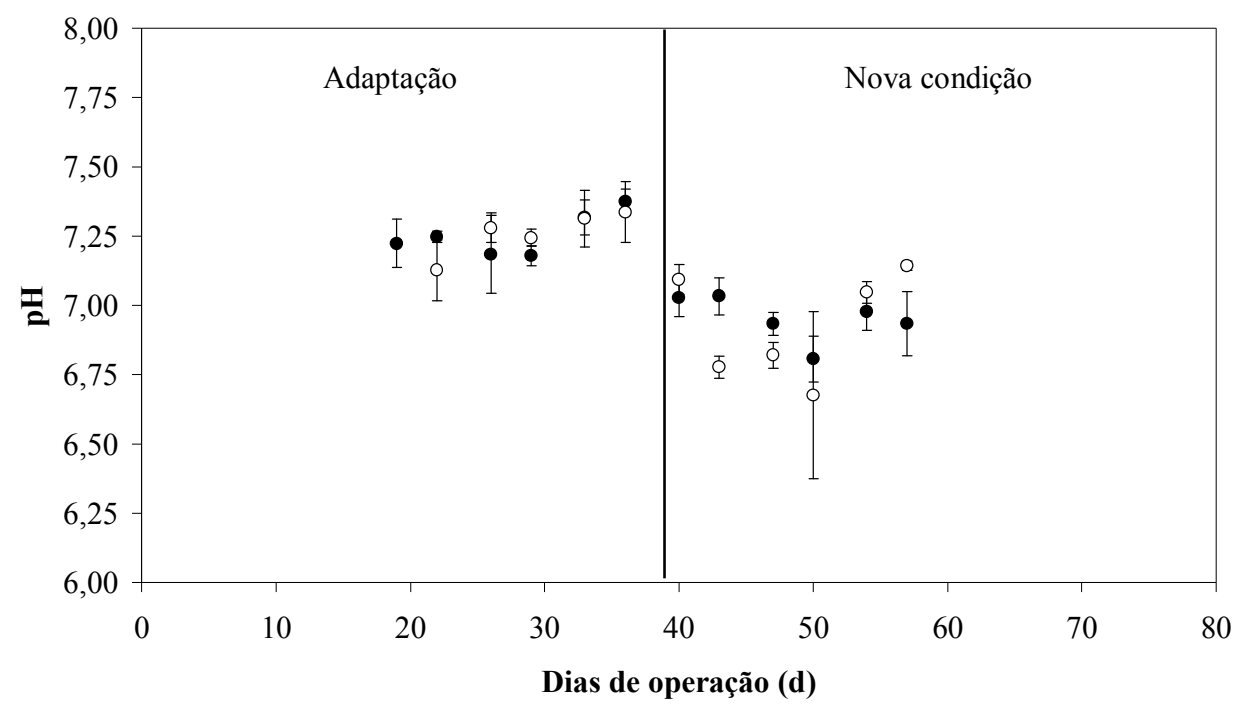

Figura 19 - Valores médios dos dados de monitoramento do pH: (•) início e (०) final do ciclo; experimento da segunda fase

Relativamente às concentrações de sulfeto medidas, novamente foi constatado o consumo praticamente completo do mesmo durante todo o período de operação (Figura 20). Também se constatou que as concentrações medidas na nova condição se aproximaram da concentração teórica adicionada. Isto foi conseguido em função de as coletas de amostras iniciais terem sido realizadas mais rapidamente que na primeira fase, imediatamente após a injeção de sulfeto, sem que houvesse atraso entre a adição da solução e coleta de amostras. Dessa forma, a perda de parte do sulfeto solúvel para o biogás presente no headspace, em função da busca do equilíbrio químico entre as espécies de sulfeto (Lei de Henry), foi minimizada.

Da mesma forma que na primeira fase, os dados de concentração de sulfato indicaram que houve formação de compostos intermediários de enxofre, visto que nem todo sulfeto adicionado foi oxidado a sulfato. No período de adaptação, observou-se maior variação entre as concentrações de sulfato ao início e final dos ciclos, visto que as concentrações de sulfeto 
aplicadas eram maiores quando comparadas com a nova condição (Figura 21): na fase de adaptação a concentração de sulfeto aplicada inicialmente foi de $30 \mathrm{mg} . \mathrm{L}^{-1}$, sendo dobrada ao final deste período; na nova condição, a concentração de sulfeto aplicada permaneceu em 15 $\mathrm{mg} . \mathrm{L}^{-1}$ durante todo o período. Dessa forma, as concentrações de sulfato formado ao final dos ciclos no período de adaptação foram maiores. Quando os frascos foram submetidos à nova condição, observou-se que as concentrações de sulfato formado ao final dos ciclos apresentaram tendência de redução ao longo do tempo, como pode ser visualizado pela distância cada vez maior no decorrer do tempo entre os valores medidos e a concentração teórica estimada caso todo o sulfeto consumido fosse oxidado a sulfato (Figura 22).

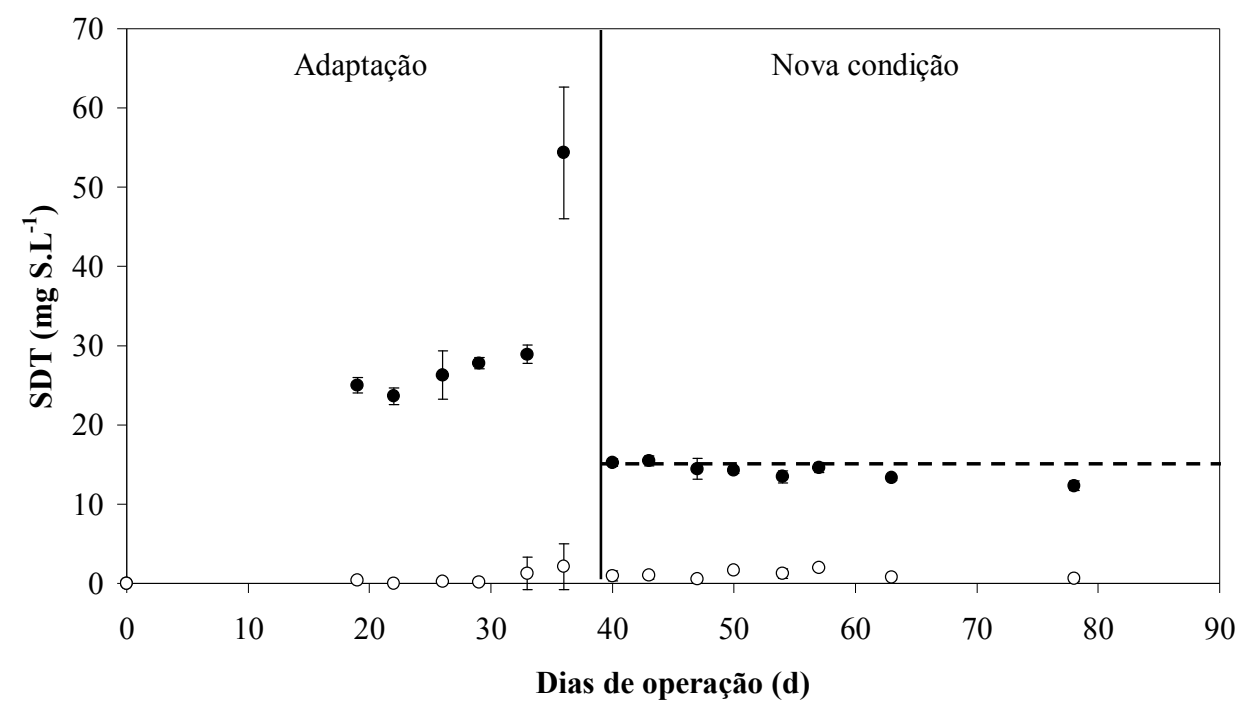

Figura 20 - Valores médios dos dados de monitoramento de sulfeto: $(\bullet)$ início e (०) final do ciclo; --concentração teórica adicionada de sulfeto; experimento da segunda fase 


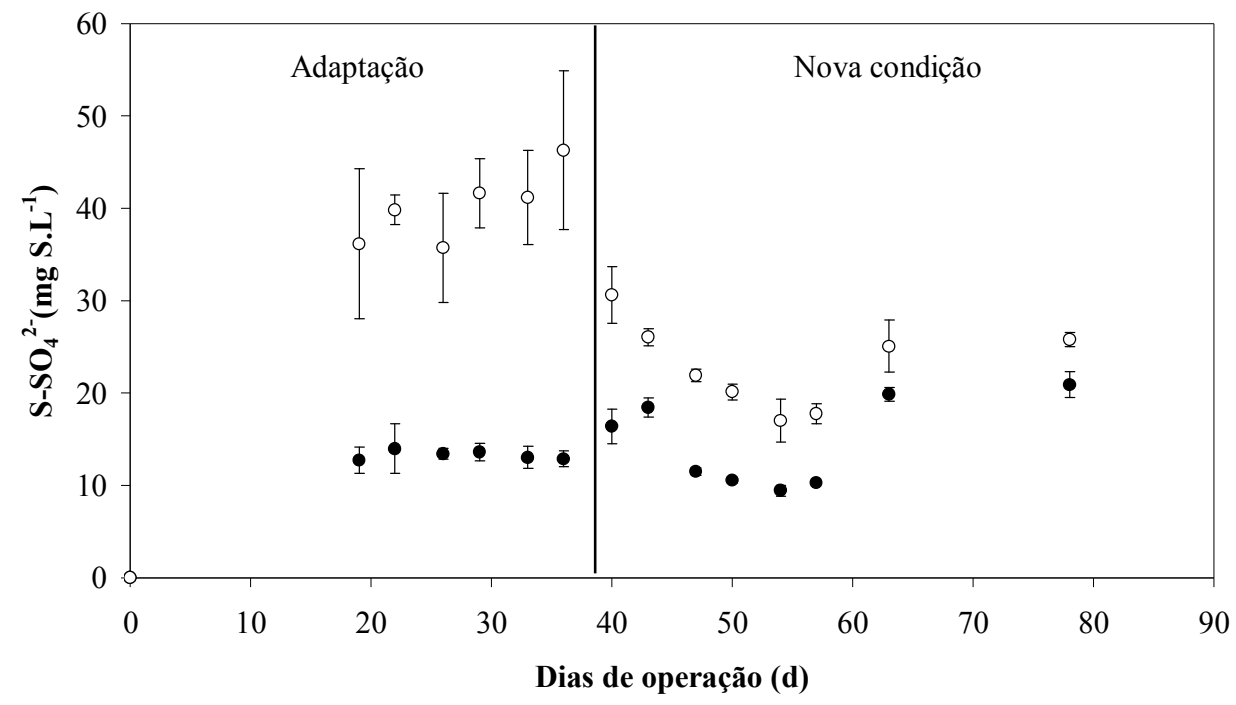

Figura 21 - Valores médios dos dados de monitoramento de sulfato: (•) início e (०) final do ciclo; experimento da segunda fase

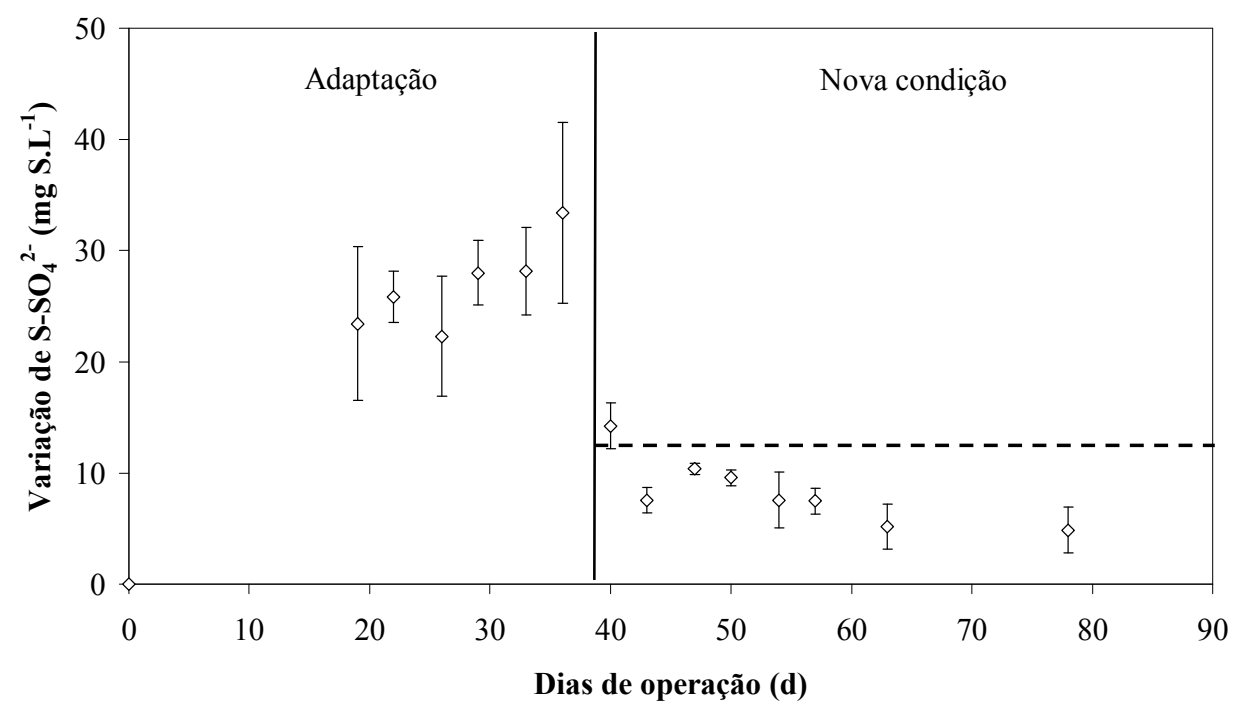

Figura 22 - Valores médios da variação de sulfato: ---- concentração teórica resultante de sulfato; experimento da segunda fase

O comportamento dos compostos oxidados de nitrogênio (Figuras 23 e 24), durante o período de adaptação, foi semelhante à primeira fase, havendo remoção incompleta de nitrato com acúmulo de nitrito quando a concentração de sulfeto aplicada passou a ser limitante (N/S $=1,6)$. Quando a concentração de sulfeto foi aumentada $(\mathrm{N} / \mathrm{S}=0,8)$, ao final do período de adaptação, os reatores tornaram-se estáveis novamente, e então, foram submetidos à nova condição. Neste caso, a concentração de sulfeto aplicada voltou a ser equivalente a estequiométrica com relação ao nitrato $(\mathrm{N} / \mathrm{S}=1,6)$, e, durante todo esse período, houve 
remoção completa de nitrato, sem formação de nitrito. Portanto, não houve a necessidade de aumentar a concentração de sulfeto aplicada como aconteceu nos experimentos da primeira fase e durante o período de adaptação destes ensaios. Desse modo, é possível que os elétrons necessários tenham sido originados de fontes adicionais, visto que, como o sulfeto foi oxidado parcialmente, não haveria elétrons suficientes para a redução completa de nitrato; entretanto, a desnitrificação completa ocorreu mantendo-se a relação N/S correspondente à estequiometria. Esta hipótese está mais detalhada no item 5.5, no qual estão apresentados os perfis temporais realizados nesta fase. Pela visualização dos perfis, foi possível analisar o comportamento de todos os compostos de interesse ao longo de um ciclo, facilitando a observação das possíveis inter-relações que fundamentam a hipótese inferida anteriormente.

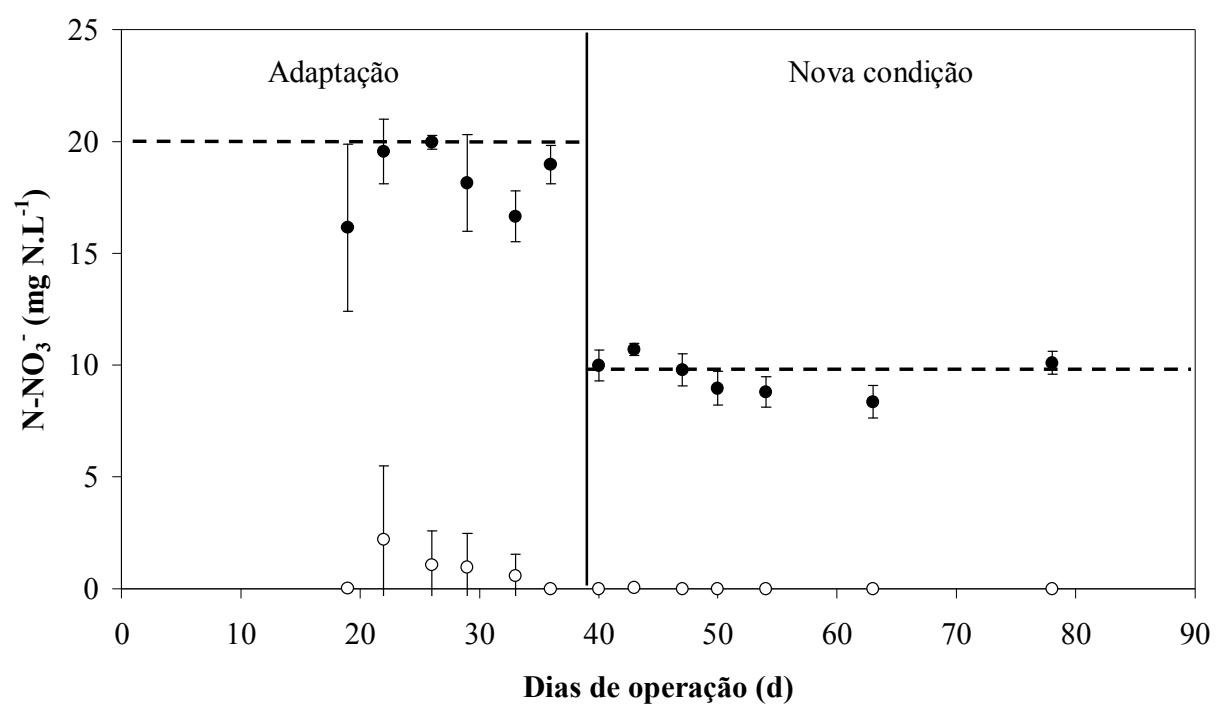

Figura 23 - Valores médios dos dados de monitoramento de nitrato: (•) início e (०) final do ciclo; ---concentração teórica adicionada de nitrato; experimento da segunda fase 


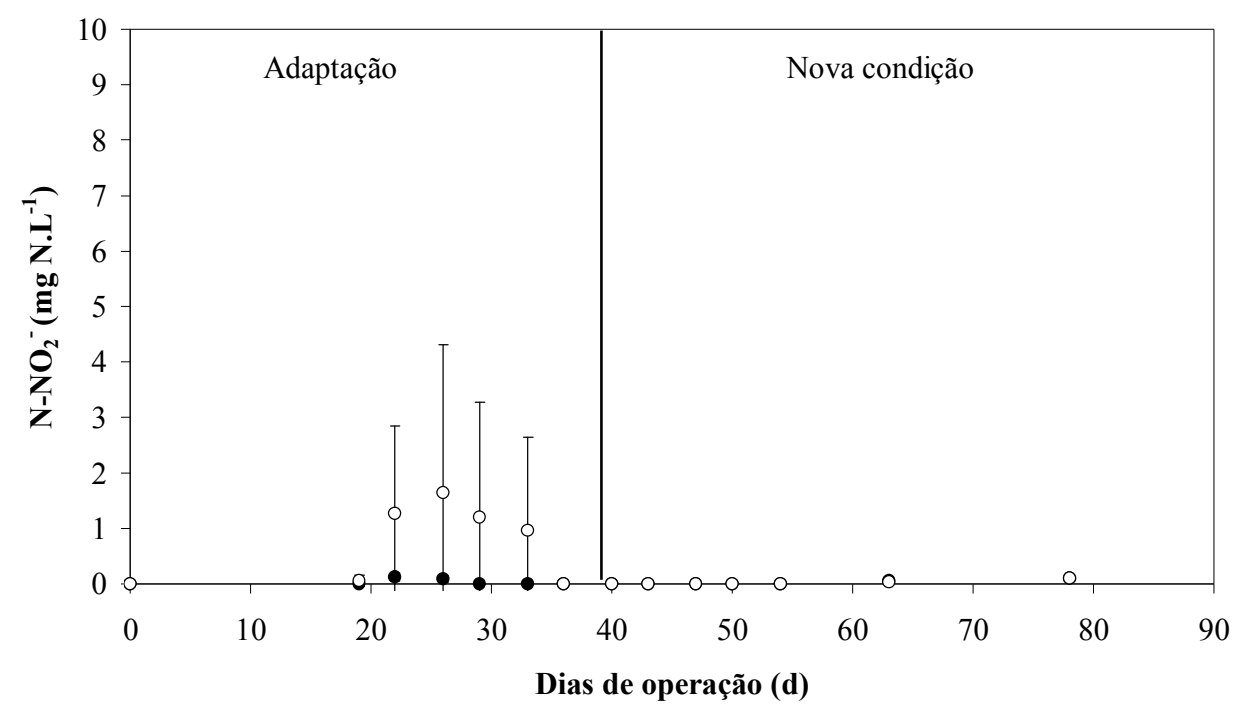

Figura 24 - Valores médios dos dados de monitoramento de nitrito: (•) início e (०) final do ciclo; experimento da segunda fase

Com relação ao nitrogênio amoniacal (Figura 25), também não foi observada, em nenhum momento, a ocorrência de RDNA, visto que não houve formação significativa deste composto entre o início e final dos ciclos. Durante a nova condição, é notável o grande aumento da concentração de nitrogênio amoniacal, que foi proporcionada pelo efluente de reator anaeróbio tratando água residuária de abatedouro de aves utilizado na nova alimentação, o qual originalmente contém elevada concentração deste composto.

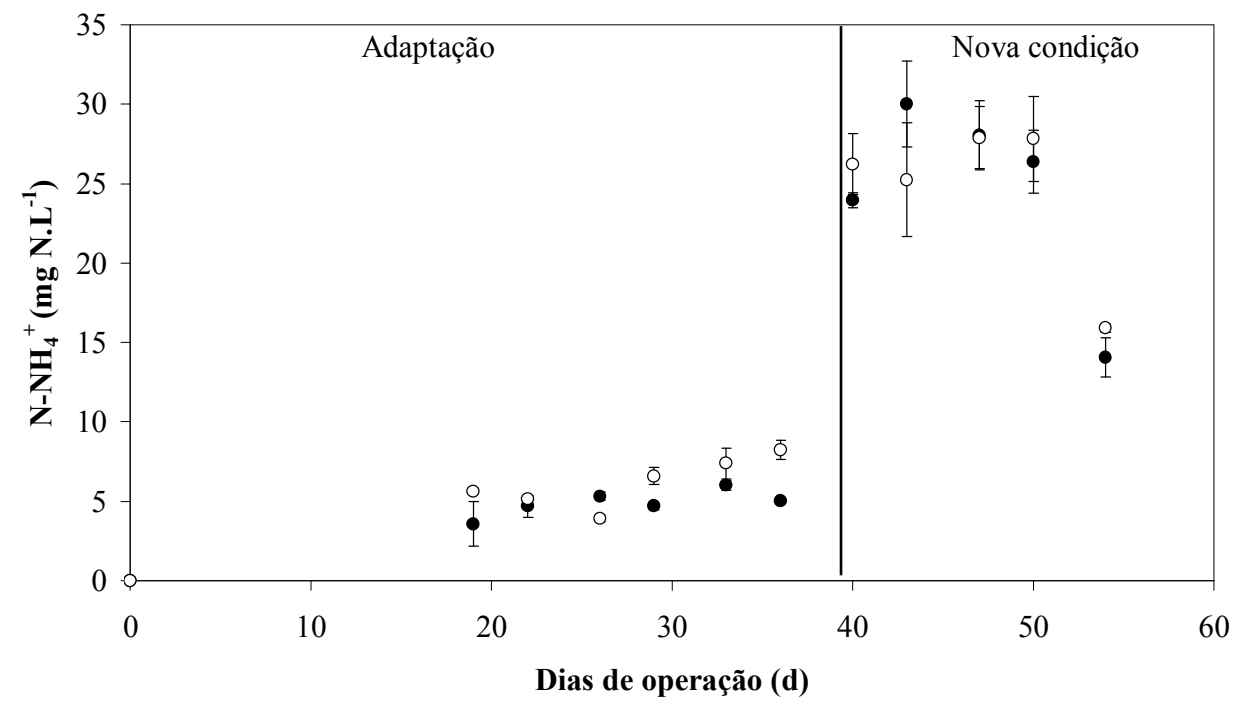

Figura 25 - Valores médios dos dados de monitoramento de nitrogênio amoniacal: $(\bullet)$ início e (०) final do ciclo; experimento da segunda fase 
A demanda química de oxigênio (DQO) total também foi monitorada durante a nova condição, com a finalidade de verificar o comportamento desta em relação à desnitrificação autotrófica. A DQO filtrada não foi monitorada tendo em vista que o volume de amostras que poderia ser retirado para análises, sem alterar o meio reacional, não seria suficiente. Optou-se, então, pelo monitoramento da DQO total, a qual está apresentada na Tabela 8.

Tabela 8 - Valores médios do monitoramento da DQO total.

\section{DQO total (mg. $\left.\mathbf{L}^{-1}\right)$}

\section{Início do ciclo}

\begin{tabular}{ccccccc}
\hline $\begin{array}{c}\text { Dias de } \\
\text { operação }\end{array}$ & Média & & $\begin{array}{c}\text { Desvio- } \\
\text { Padrão }\end{array}$ & Média & & $\begin{array}{c}\text { Desvio- } \\
\text { Padrão }\end{array}$ \\
43 & 78,25 & \pm & 35,31 & 45,47 & \pm & 1,77 \\
47 & 109,35 & \pm & 24,16 & 140,71 & \pm & 40,97 \\
50 & 112,30 & \pm & 24,72 & 63,92 & \pm & 13,92 \\
54 & 43,72 & \pm & 11,13 & 45,86 & \pm & 32,35 \\
57 & 96,26 & \pm & 21,44 & 43,51 & \pm & 8,30 \\
63 & 90,30 & \pm & 21,93 & 76,83 & \pm & 18,49 \\
78 & 61,39 & \pm & 16,87 & 38,59 & \pm & 21,38 \\
\hline
\end{tabular}

Observa-se que, de maneira geral, os valores de DQO foram reduzidos ao final do ciclo, indicando que parte da matéria orgânica de difícil degradação, presente no efluente de reator anaeróbio tratando água residuária de abatedouro de aves utilizado na alimentação, foi utilizada. Vale ressaltar que os resultados de DQO obtidos tiveram interferência de sólidos suspensos contidos em grande quantidade no efluente de aves, fato que possivelmente explica o alto desvio-padrão das triplicatas, em função da dificuldade em homogeneizar o efluente de abatedouro de aves, proveniente de reator UASB, de maneira uniforme para todas as triplicatas. Além disso, os valores medidos no início dos ciclos, assim como no final, 
apresentaram variações ao longo dos dias de operação, provavelmente devido à presença de sólidos suspensos.

\subsection{PERFIS TEMPORAIS - PRIMEIRA FASE}

\subsubsection{Nitrato como receptor de elétrons}

Após estabilização dos reatores, com desnitrificação completa na condição de N/S de 0,8 , foram realizados dois perfis temporais com duração de um ciclo e coleta de amostras principalmente nas primeiras oito horas. Nos perfis, foi analisado o comportamento de sulfeto (SDT), de sulfato $\left(\mathrm{S}-\mathrm{SO}_{4}{ }^{2-}\right)$ e da formas oxidadas de nitrogênio $\left(\mathrm{N}^{-\mathrm{NO}_{3}}{ }^{-} ; \mathrm{N}_{-} \mathrm{NO}_{2}{ }^{-}\right)$, conforme pode ser visualizado nas Figuras 26, 27 e 28, referentes à RI1, RI2 e RI3, respectivamente.

Em todos os reatores foi observada a remoção completa de nitrato, sem geração de nitrito, com consumo total de sulfeto. Entretanto, o consumo total de sulfeto ocorreu antes do término da desnitrificação completa, fato que comprova a formação de compostos intermediários de enxofre que poderiam ser utilizados como doadores de elétrons para remover o restante de nitrato na ausência de sulfeto. Para reforçar esta afirmação, a produção de sulfato teve aumento significativo apenas ao final do ciclo, não acompanhando o decaimento de sulfeto. Além disso, observou-se que a coloração do meio líquido no interior dos frascos foi tornando-se esbranquiçada e amarelada ao longo do tempo, sendo que ao final do ciclo o líquido tornou-se incolor novamente. Tais observações também foram constatadas por Reyes-Avila et al. (2004) em ensaios cinéticos que avaliaram a desnitrificação autotrófica na presença de sulfeto, utilizando biomassa suspensa previamente adaptada. Os autores constataram que a oxidação de sulfeto ocorreu em duas etapas: primeiro o sulfeto foi oxidado a tiossulfato e enxofre elementar, e posteriormente, estes últimos foram oxidados a sulfato, sendo esta etapa mais lenta que a primeira. 
Utilização de sulfeto como doador de elétrons para a desnitrificação autotrófica aplicada ao tratamento de esgoto sanitário

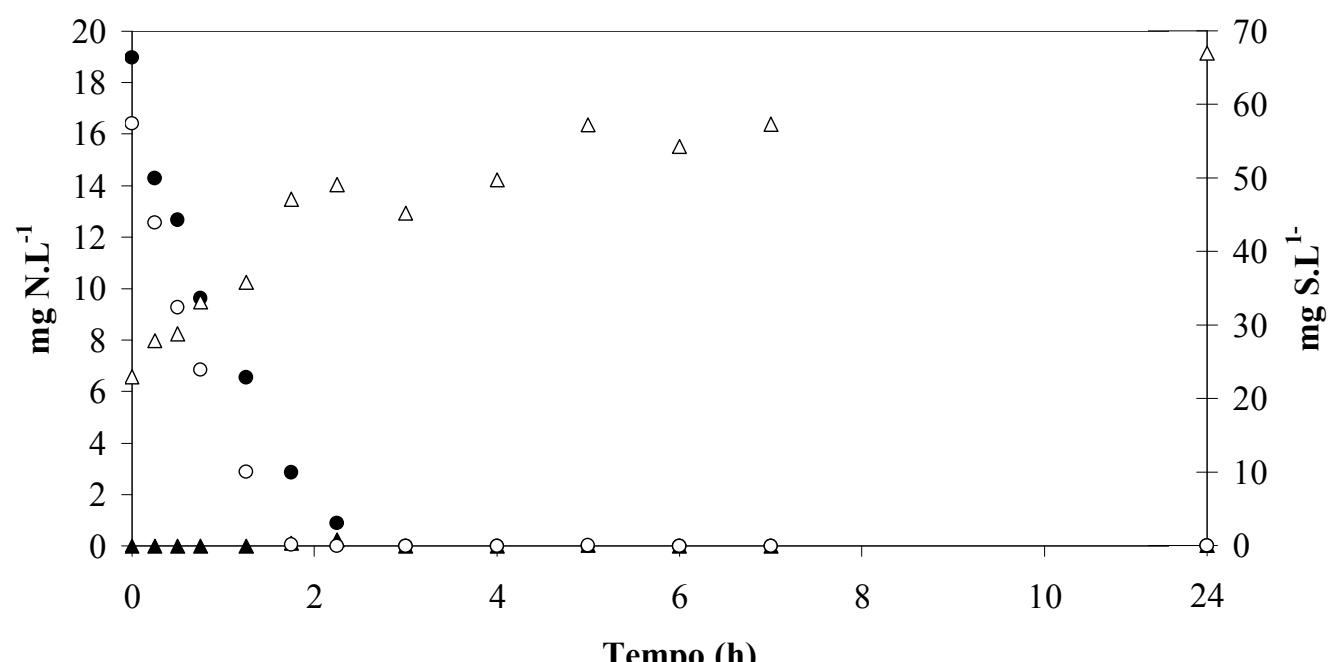

Figura 26 - Primeiro perfil temporal dos parâmetros durante um ciclo de 24 horas, com emprego de nitrato como receptor de elétrons, em RI1: $(\bullet) \mathrm{N}^{-N_{3}}{ }_{3}^{-} ;(\boldsymbol{\Delta}) \mathrm{N}_{-} \mathrm{NO}_{2}{ }^{-} ;(0) \mathrm{SDT} ;(\Delta) \mathrm{S}^{-\mathrm{SO}_{4}}{ }^{2-}$

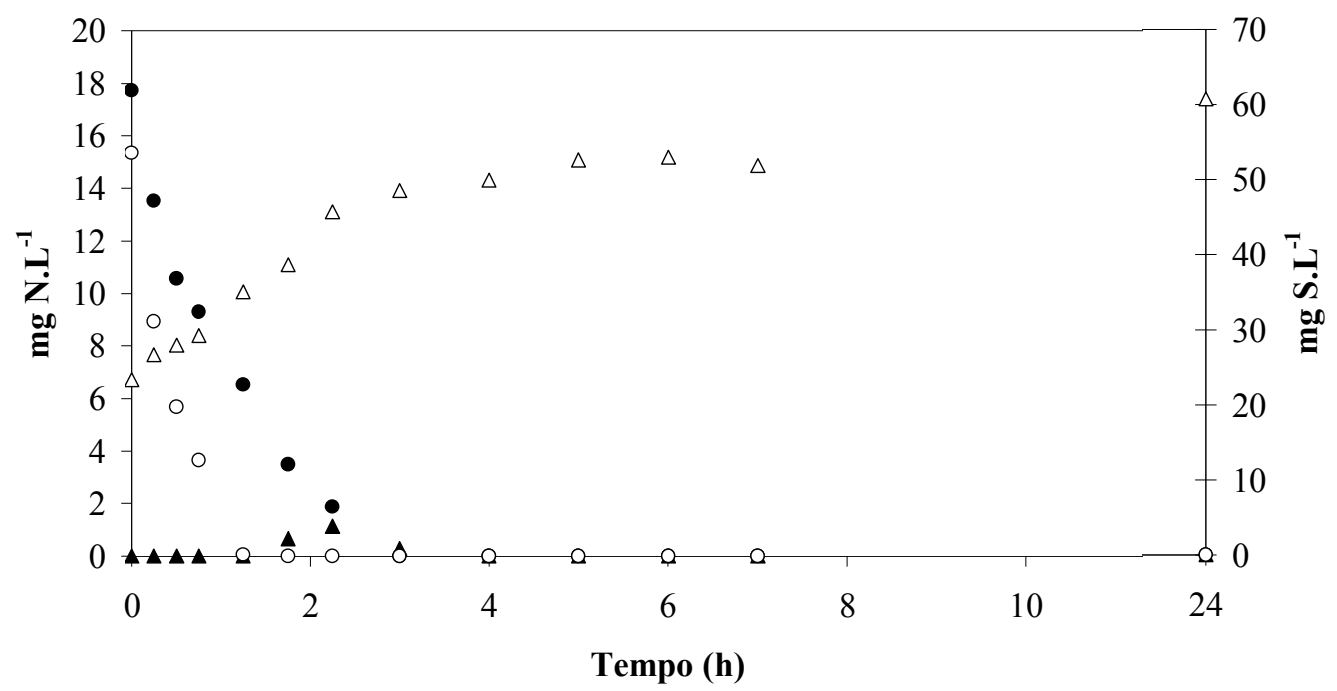

Figura 27 - Primeiro perfil temporal dos parâmetros durante um ciclo de 24 horas, com emprego de

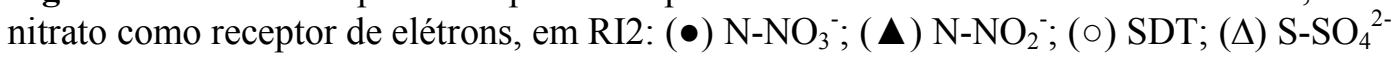

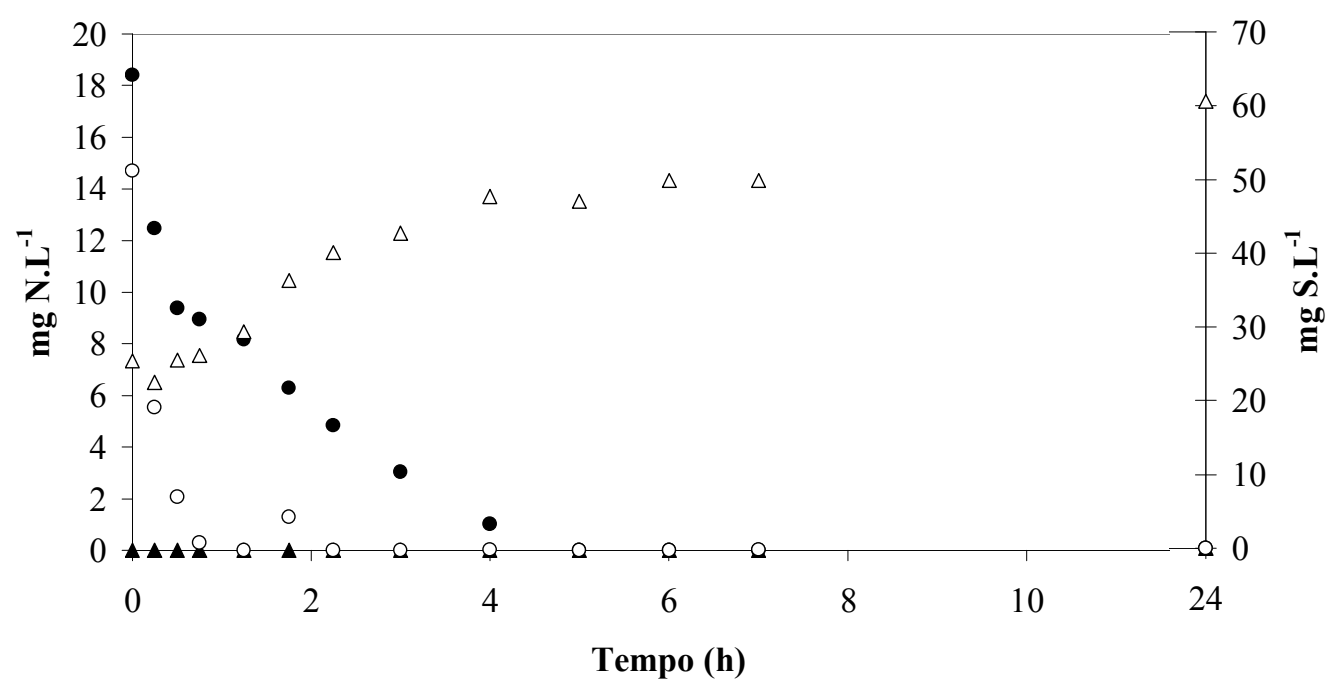

Figura 28 - Primeiro perfil temporal dos parâmetros durante um ciclo de 24 horas, com emprego de nitrato como receptor de elétrons, em RI3: $(\bullet) \mathrm{N}^{-N_{3}}{ }_{3}^{-} ;(\boldsymbol{\Delta}) \mathrm{N}^{-N_{2}}{ }_{2}^{-} ;(0) \mathrm{SDT} ;(\Delta) \mathrm{S}^{-\mathrm{SO}_{4}}{ }^{2-}$ 
Após a realização do primeiro perfil, os reatores foram submetidos a um choque de temperatura, em função de problemas no painel de controle da câmara climatizada, que causaram o aumento não intencional da temperatura para $65^{\circ} \mathrm{C}$. Os reatores permaneceram nesta temperatura por no máximo 5 horas. Para verificar a situação da biomassa após este aquecimento, foram realizadas microscopias de contraste de fase, que indicaram a não destruição total de células. Desse modo, optou-se por continuar este experimento, sendo realizado o segundo perfil temporal.

Nas Figuras 29, 30 e 31 estão apresentados os parâmetros de interesse analisados durante um ciclo, referentes à RI1, RI2 e RI3, respectivamente. Novamente, foi observada desnitrificação completa, sem formação de nitrito, em todos os reatores. Entretanto, este processo ocorreu em maior tempo quando comparado ao primeiro perfil, fato que provavelmente foi devido ao choque de temperatura, o qual deve ter ocasionado perda de parte da biomassa ativa.

Como no perfil anterior, o consumo total de sulfeto ocorreu antes do término da desnitrificação completa, indicando formação de compostos intermediários de enxofre. Além disso, o sulfato produzido ao final do ciclo foi muito inferior à concentração teórica relacionada ao sulfeto consumido (cerca de $60 \mathrm{mgS}-\mathrm{SO}_{4}{ }^{2-} \cdot \mathrm{L}^{-1}$ ), ficando abaixo de $20 \mathrm{mgS}-$ $\mathrm{SO}_{4}{ }^{2-} \cdot \mathrm{L}^{-1}$. Desse modo, não foi possível fechar o balanço de massa de enxofre. 


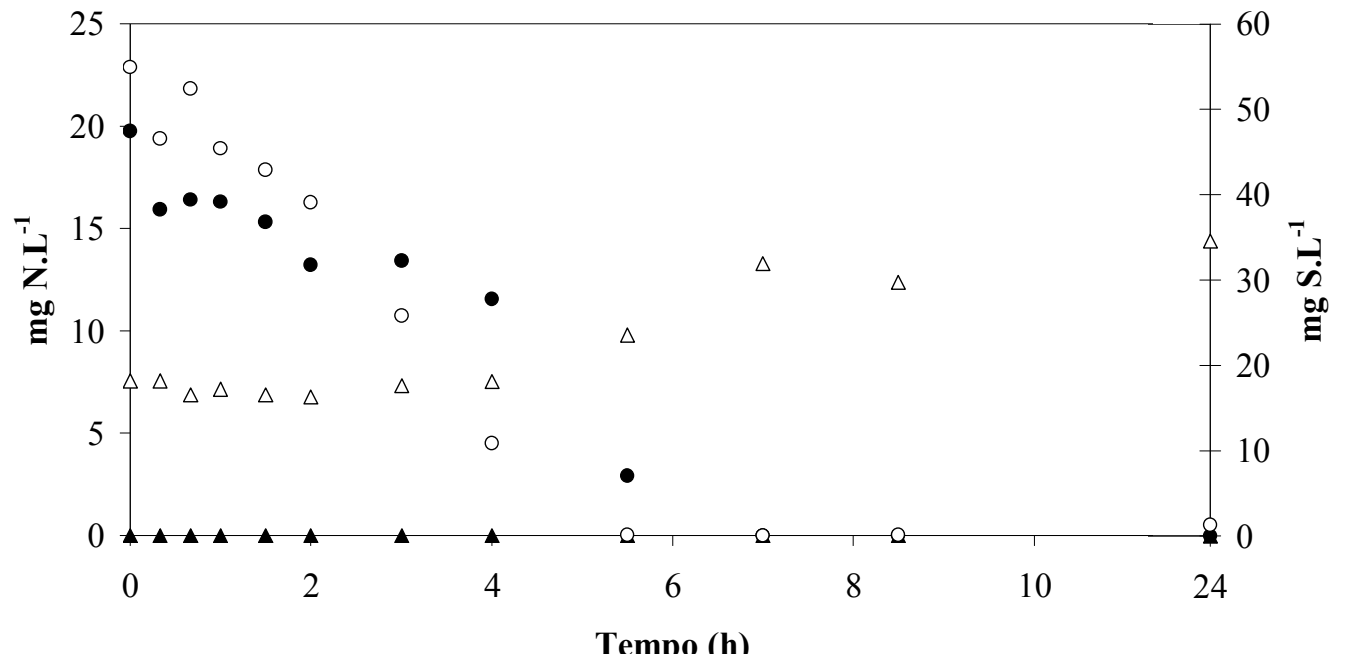

Figura 29 - Segundo perfil temporal dos parâmetros durante um ciclo de 24 horas, com emprego de nitrato como receptor de elétrons, em RI1: $(\bullet) \mathrm{N}^{-N_{3}}{ }_{3}^{-} ;(\boldsymbol{\Delta}) \mathrm{N}_{-} \mathrm{NO}_{2}{ }^{-} ;(0) \mathrm{SDT} ;(\Delta) \mathrm{S}^{-\mathrm{SO}_{4}}{ }^{2-}$

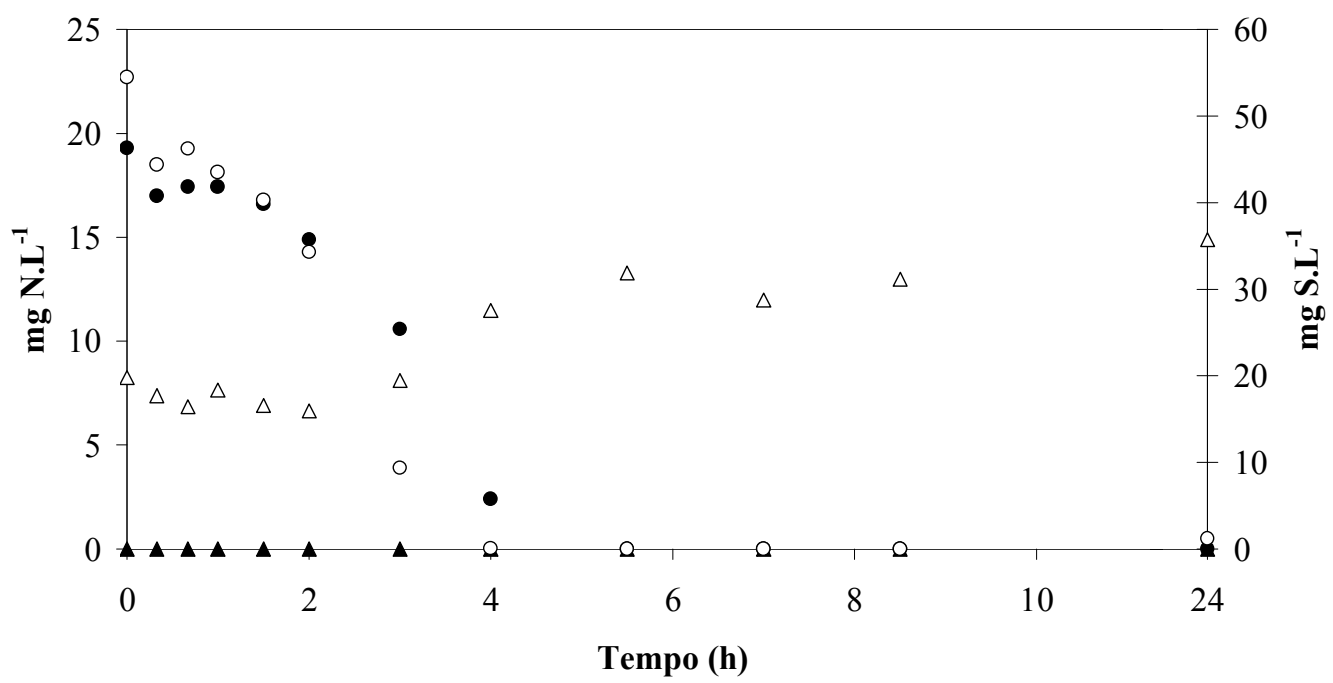

Figura 30 - Segundo perfil temporal dos parâmetros durante um ciclo de 24 horas, com emprego de

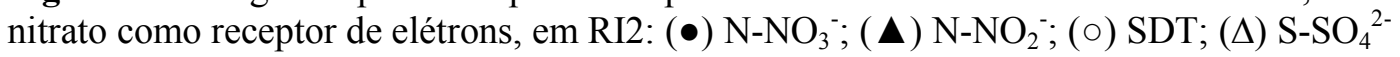

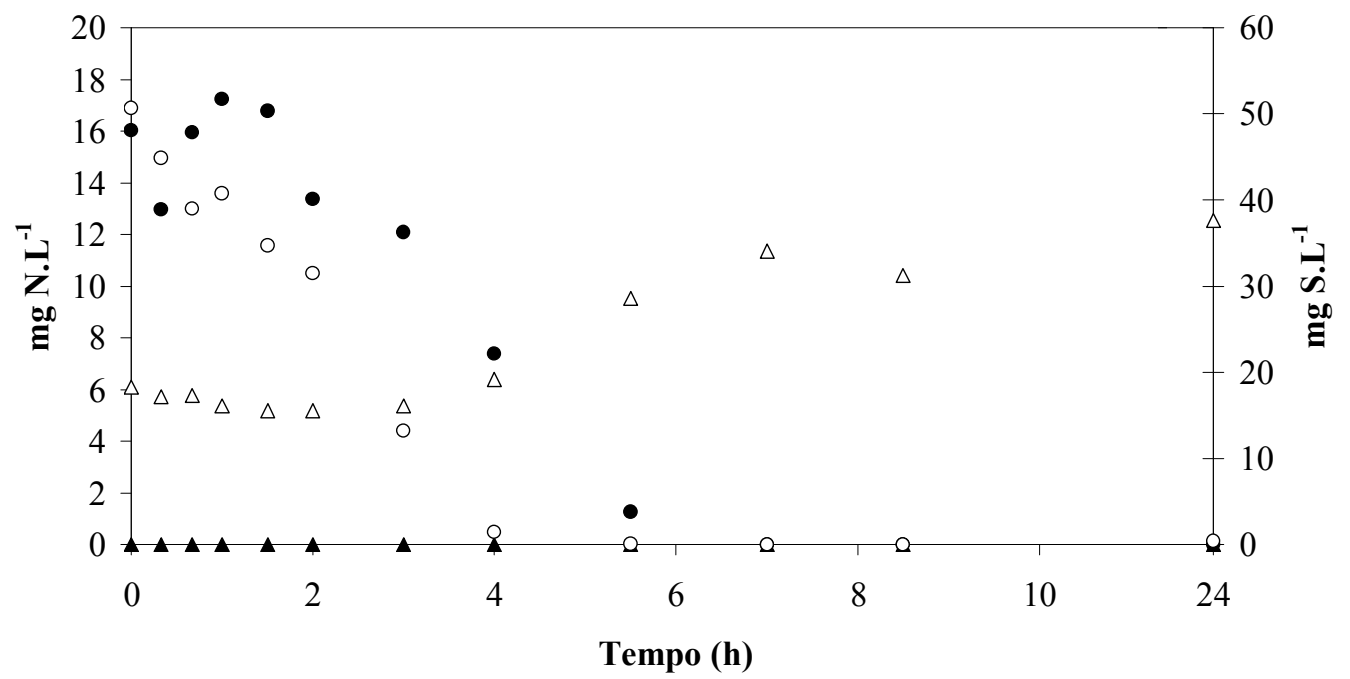

Figura 31 - Segundo perfil temporal dos parâmetros durante um ciclo de 24 horas, com emprego de nitrato como receptor de elétrons, em RI3: $(\bullet) \mathrm{N}^{-N_{3}}{ }_{3}^{-} ;(\boldsymbol{\Delta}) \mathrm{N}^{-N}{ }_{2}^{-} ;(\circ) \mathrm{SDT} ;(\Delta) \mathrm{S}^{-} \mathrm{SO}_{4}{ }^{2-}$ 


\subsubsection{Nitrito como receptor de elétrons}

Verificada a estabilidade dos reatores, com desnitrificação completa na condição de $\mathrm{N} / \mathrm{S}$ de 1,4 , realizou-se um perfil temporal com duração de um ciclo e coleta de amostras principalmente nas primeiras nove horas. A realização de apenas um perfil foi devida ao mesmo problema de aquecimento da câmara climatizada ocorrido no experimento anterior (nitrato como receptor de elétrons). Neste caso, a temperatura atingiu $100^{\circ} \mathrm{C}$, causando a morte dos microrganismos de interesse e impossibilitando a realização do segundo perfil.

Os dados de concentração dos parâmetros de interesse estão ilustrados nas Figuras 32, 33 e 34, referentes à RI1, RI2 e RI3, respectivamente.

Neste ensaio, o comportamento das triplicatas foi bastante desigual; todavia, a desnitrificação completa a partir de nitrito ocorreu nos três reatores, em tempos distintos. Comparando com os resultados obtidos nos experimentos anteriores, com aplicação de nitrato como receptor de elétrons, a desnitrificação completa com nitrito levou mais tempo para acontecer, sendo detectada ausência de nitrito somente após oito horas. No caso de RI2, o consumo total de nitrito não foi detectado nas primeiras nove horas em que foram feitas as coletas de amostra, não sendo possível inferir o tempo aproximado da remoção completa de nitrito. Em todos os frascos, não foi detectado nitrato em níveis significativos.

Os compostos de enxofre tiveram comportamento semelhante ao segundo perfil do ensaio anterior: o consumo total de sulfeto ocorreu anteriormente ao término da desnitrificação completa, e a concentração de sulfato produzido ao final do ciclo foi inferior à concentração teórica relacionada ao sulfeto consumido (cerca de $34 \mathrm{mgS}-\mathrm{SO}_{4}{ }^{2-} \cdot \mathrm{L}^{-1}$ ), ficando em torno de $9 \mathrm{mgS}-\mathrm{SO}_{4}{ }^{2-} \cdot \mathrm{L}^{-1}$. Além disso, a coloração do líquido no interior dos frascos também foi alterada. Portanto, houve a formação de compostos intermediários de enxofre durante o processo. 
Utilização de sulfeto como doador de elétrons para a desnitrificação autotrófica aplicada ao tratamento de esgoto sanitário

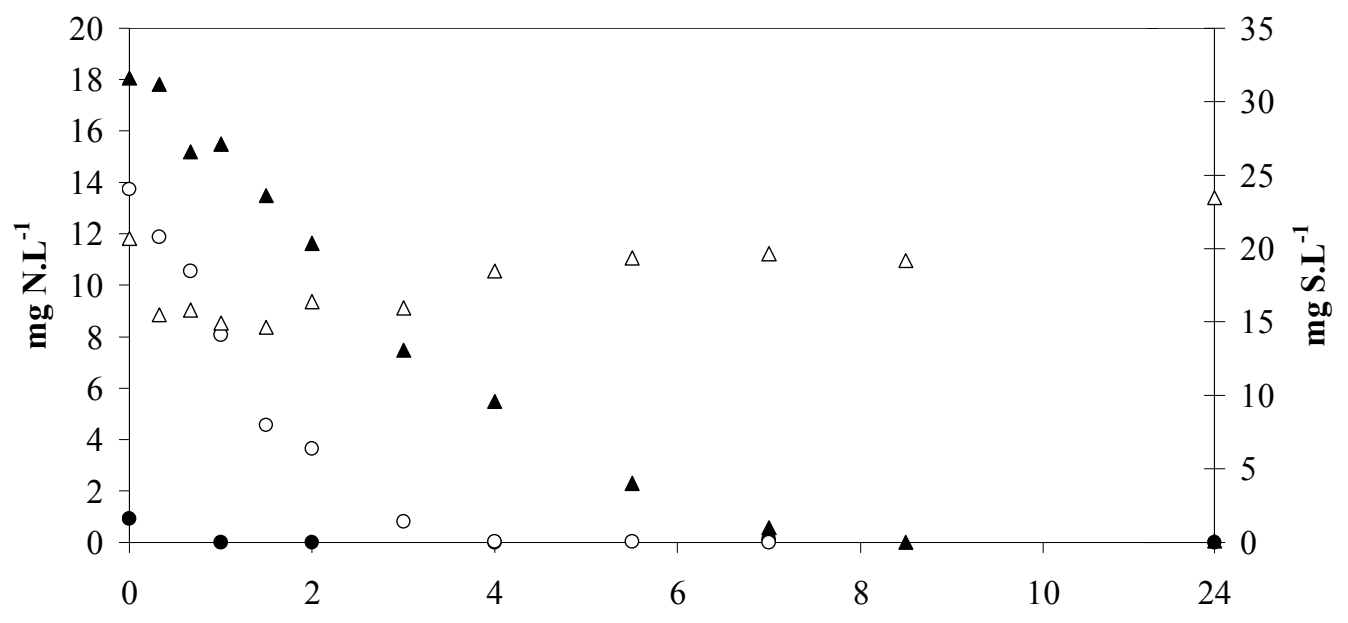

Tempo (h)

Figura 32 - Perfil temporal dos parâmetros durante um ciclo de 24 horas, com emprego de nitrito

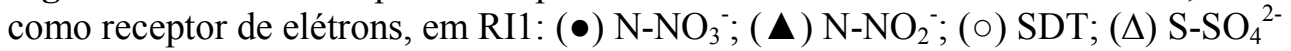

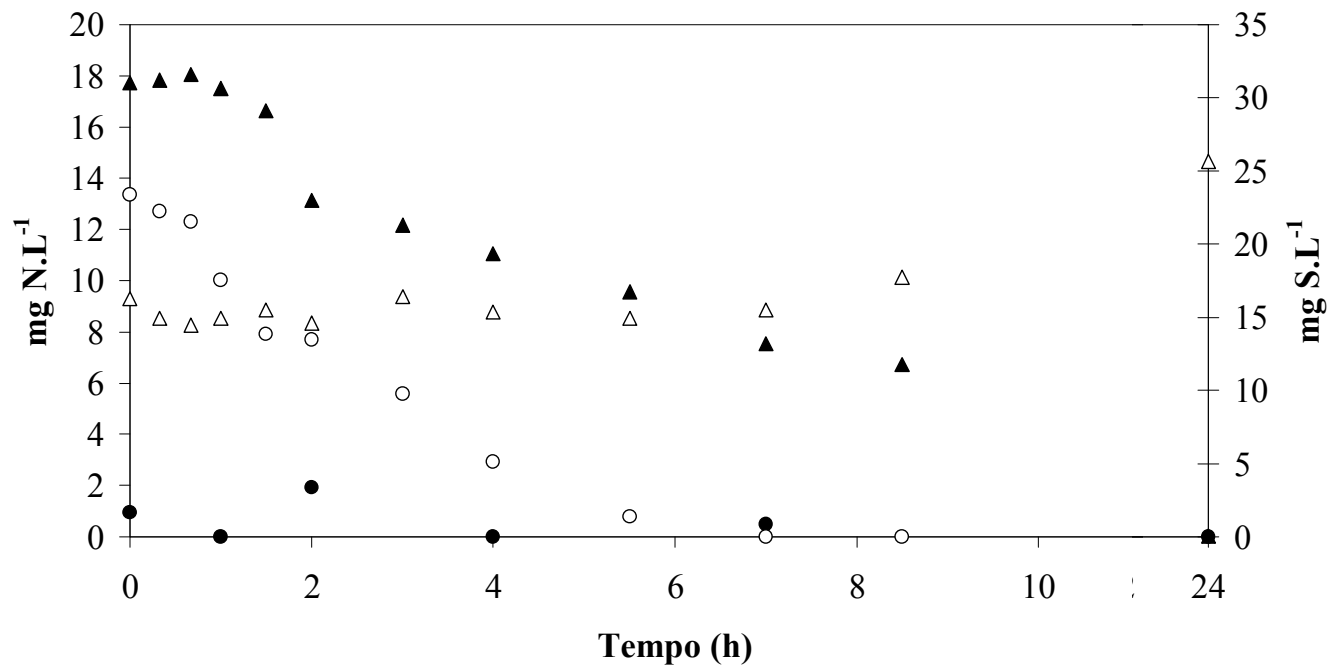

Figura 33 - Perfil temporal dos parâmetros durante um ciclo de 24 horas, com emprego de nitrito

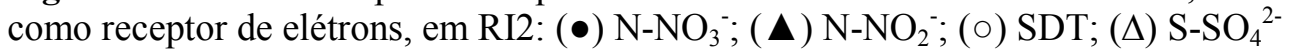

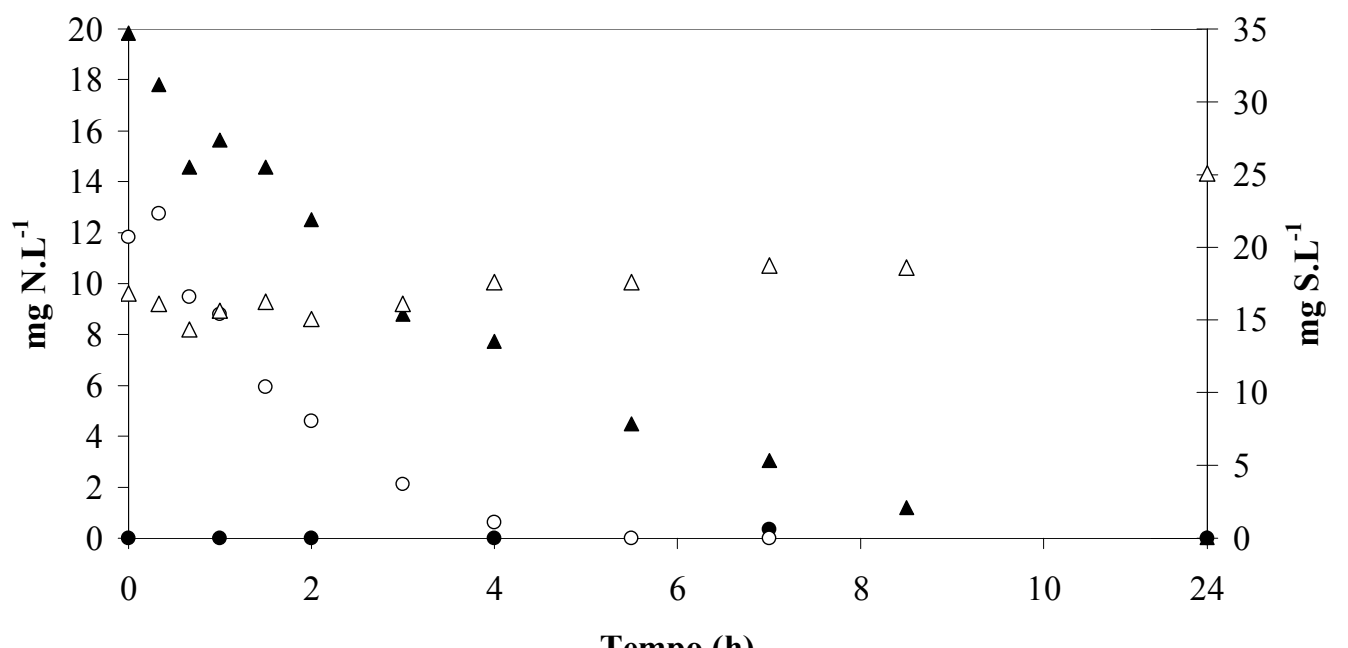

Tempo (h)

Figura 34 - Perfil temporal dos parâmetros durante um ciclo de 24 horas, com emprego de nitrito como receptor de elétrons, em RI3: $(\bullet) \mathrm{N}^{-N_{3}}{ }_{3}^{-} ;(\boldsymbol{\Delta}) \mathrm{N}_{-} \mathrm{NO}_{2}^{-} ;(\circ) \mathrm{SDT} ;(\Delta) \mathrm{S}_{-} \mathrm{SO}_{4}{ }^{2-}$ 
Posteriormente a estes perfis temporais, os reatores deste ensaio foram desmontados em função do aquecimento a $100^{\circ} \mathrm{C}$ causado por falhas técnicas no painel de controle da câmara climatizada, o qual ocasionou a destruição total de células. Este fato impossibilitou a realização do segundo perfil temporal de concentração dos compostos de interesse com o emprego de nitrito como receptor de elétrons.

\subsection{PERFIS TEMPORAIS - SEGUNDA FASE}

Após estabilização dos reatores, com desnitrificação completa na condição de N/S de 1,6 foram realizados dois perfis temporais com duração de um ciclo e coleta de amostras principalmente nas primeiras dez horas. Nas Figuras 35, 36 e 37 estão apresentadas as concentrações dos compostos analisados no decorrer do ciclo, referentes à RI1, RI2 e RI3, respectivamente.

O comportamento das triplicatas foi muito similar, com relação a todos os compostos analisados. O sulfeto adicionado foi totalmente consumido muito antes do término da desnitrificação completa, com mais de 3 horas de antecedência. Além disso, a geração de sulfato não teve aumento significativo ao longo do ciclo. Portanto, a formação de compostos intermediários de enxofre, como enxofre elementar, ocorreu; todavia, a pequena formação de sulfato ao final do ciclo indica que estes compostos não foram totalmente oxidados, e desse modo, a possibilidade de terem sido utilizados como doadores de elétrons é pequena. Além disso, segundo Koenig e Liu (2001), o fator limitante para a desnitrificação com uso de enxofre elementar é a baixa solubilidade deste composto em água à temperatura ambiente. Este doador só seria utilizado pelos microrganismos após a solubilização e difusão na biomassa. 


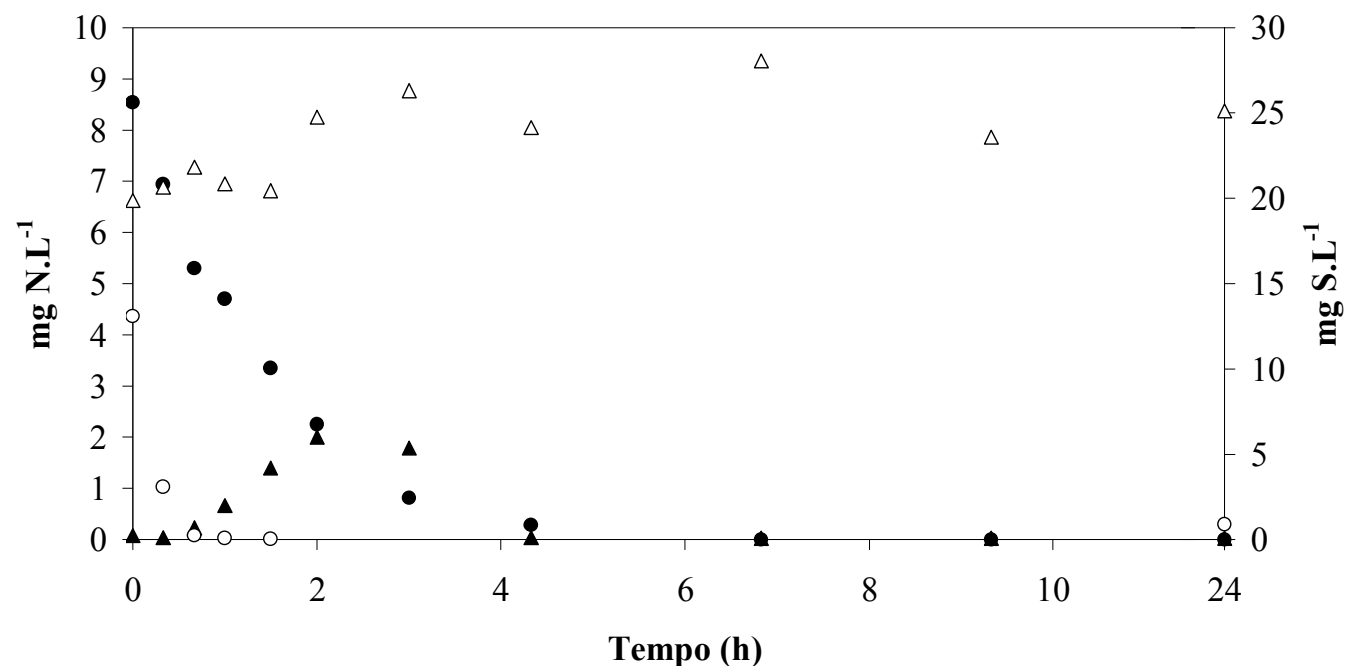

Figura 35 - Primeiro perfil temporal dos parâmetros durante um ciclo de 24 horas, com emprego de

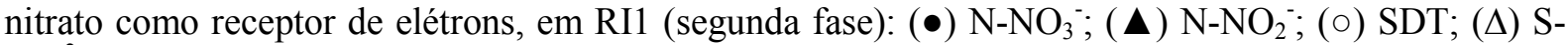
$\mathrm{SO}_{4}{ }^{2-}$

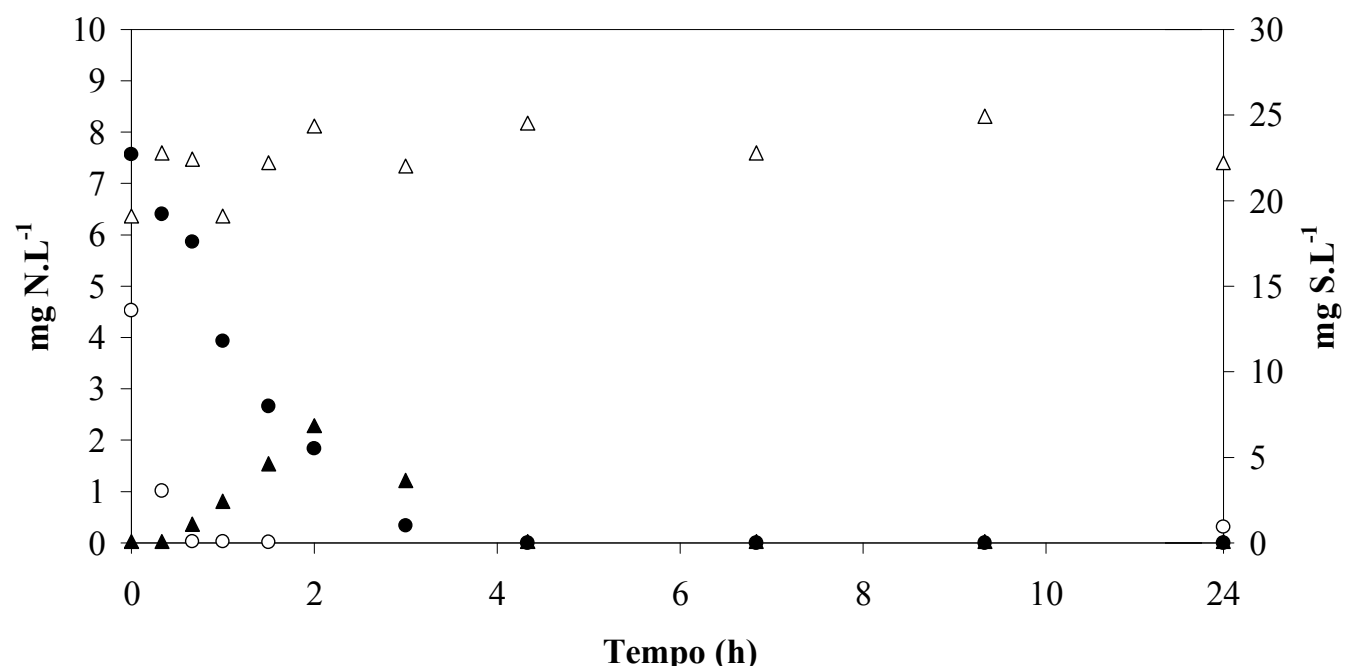

Figura 36 - Primeiro perfil temporal dos parâmetros durante um ciclo de 24 horas, com emprego de nitrato como receptor de elétrons, em RI2 (segunda fase): $(\bullet) \mathrm{N}^{-N^{-}}{ }_{3}^{-} ;(\boldsymbol{\Delta}) \mathrm{N}^{-\mathrm{NO}_{2}}{ }^{-}$; (०) SDT; $(\Delta) \mathrm{S}-$ $\mathrm{SO}_{4}{ }^{2-}$

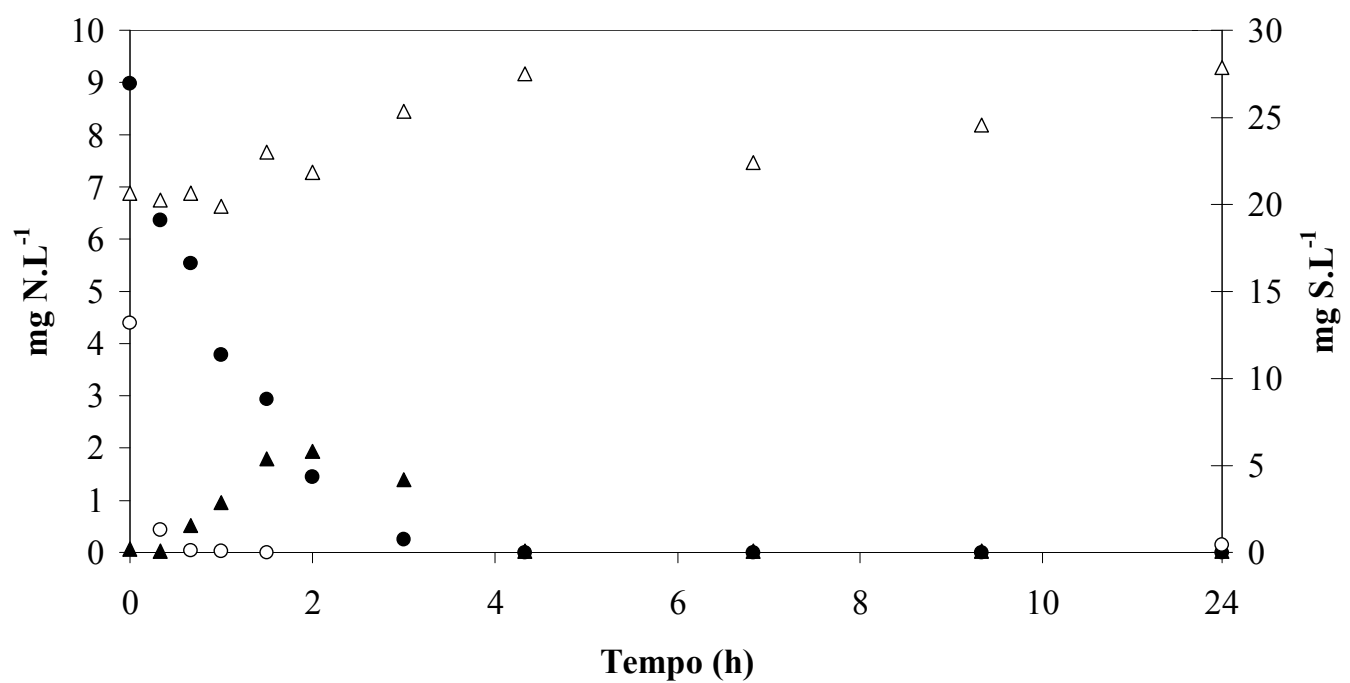

Figura 37 - Primeiro perfil temporal dos parâmetros durante um ciclo de 24 horas, com emprego de nitrato como receptor de elétrons, em RI3 (segunda fase): $(\bullet) \mathrm{N}^{-N^{-}}{ }_{3}^{-} ;(\boldsymbol{\Delta}) \mathrm{N}^{-\mathrm{NO}_{2}}{ }^{-} ;(\circ) \mathrm{SDT} ;(\Delta) \mathrm{S}-$ $\mathrm{SO}_{4}{ }^{2-}$ 
Nos três reatores também foi observada a geração de nitrito logo após o consumo de sulfeto, fato que está diretamente relacionado com a formação de enxofre elementar por meio da oxidação incompleta de sulfeto, como explicado no item 5.2.1. Ao contrário do que ocorreu durante a primeira fase com aplicação de nitrato como receptor, o nitrito foi totalmente consumido juntamente com o restante de nitrato, sendo mantida a relação N/S de 1,6 , correspondente a estequiometria relativa a sulfeto e nitrato, ou seja, não havia excesso do doador de elétrons. Na primeira fase, o nitrito só passou a ser consumido quando a concentração do doador de elétrons (sulfeto) foi dobrada $(\mathrm{N} / \mathrm{S}=0,8)$.

A oxidação incompleta de sulfeto, a não formação de sulfato ao final do ciclo e a geração de nitrito indicam que os elétrons fornecidos para a desnitrificação completa foram insuficientes, em função da menor quantidade de elétrons liberados na oxidação parcial de sulfeto quando comparada com a oxidação total. Este fato foi observado durante o monitoramento realizado na primeira fase utilizando nitrato como receptor, na qual a desnitrificação foi incompleta quando a relação N/S mantida foi equivalente a estequiométrica (item 5.2.1.). Contrariamente à primeira fase, nesta nova condição o nitrito gerado foi seqüencialmente consumido e a desnitrificação completa ocorreu na relação N/S estequiométrica relativamente a sulfeto e nitrato, não sendo observada a necessidade de se elevar a concentração do doador de elétrons utilizado. Assim, surge a hipótese da existência de fontes adicionais de elétrons, as quais poderiam estar presentes no efluente de abatedouro de aves, proveniente de reator UASB, utilizado na nova condição. Tendo em vista a complexidade de tal efluente e visto que apresenta composição pouco conhecida no que se refere à matéria orgânica de difícil degradação, infere-se a possibilidade de o mesmo conter fontes de elétrons para redução de nitrato e nitrito associada à desnitrificação com uso de sulfeto. Esses compostos adicionais forneceriam os elétrons necessários para a desnitrificação 

ao tratamento de esgoto sanitário

completa, que seriam insuficientes caso o único doador de elétrons fosse o sulfeto na relação N/S estequiométrica e os produtos finais não incluíssem a formação de sulfato.

Em comparação com o primeiro perfil de sulfeto realizado na primeira etapa, o consumo total de sulfeto neste perfil ocorreu em menor tempo, cerca de 2 horas antes. ReyesAvila et al. (2004) também observaram que o consumo de sulfeto ocorreu mais rapidamente quando havia matéria orgânica no sistema. Estes autores avaliaram a desnitrificação na presença concomitante de acetato e sulfeto, e concluíram que a desnitrificação autotrófica na presença de acetato incrementaram as velocidades de consumo de sulfeto e nitrato.

Também foi analisada a variação temporal da DQO total, conforme apresentado na Figura 38. De maneira geral, observa-se o aumento da concentração da DQO nas primeiras 3 horas do perfil, com subseqüente redução em todos os reatores. Ao final do ciclo, a concentração da DQO foi ligeiramente menor que ao início do ciclo, com exceção de RI3, na qual estas concentrações foram mais próximas.

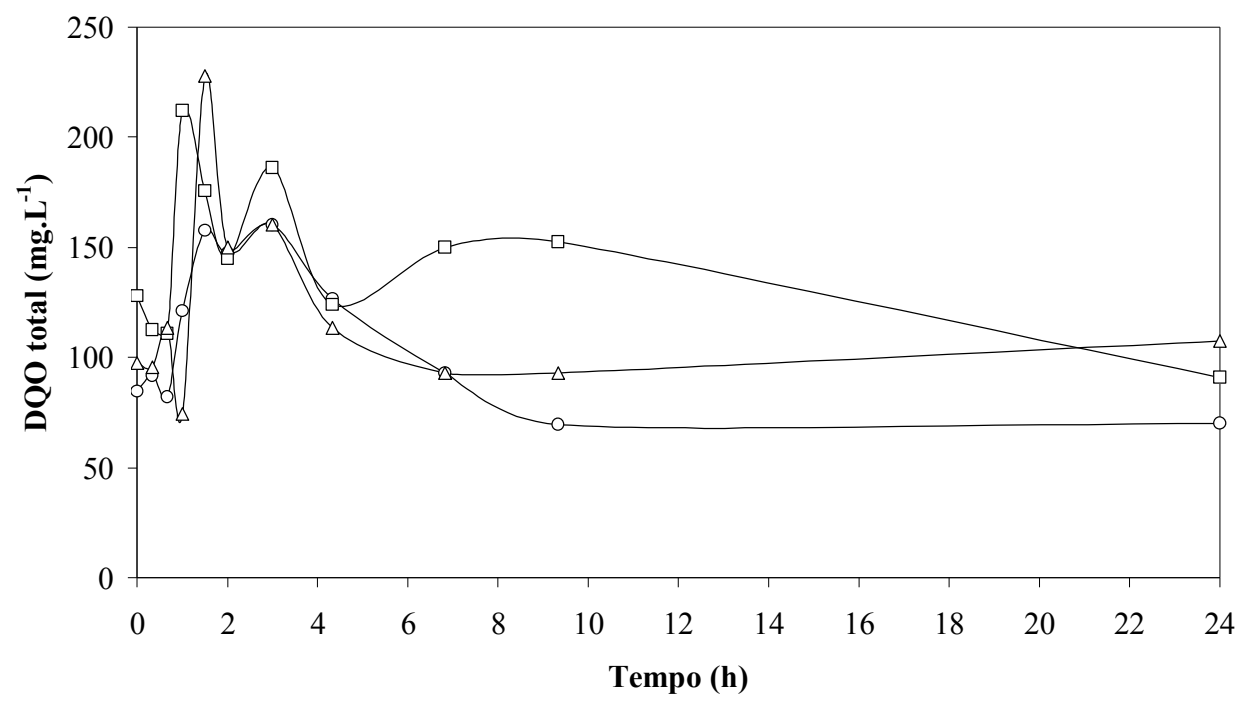

Figura 38 - Primeiro perfil temporal da DQO total durante um ciclo de 24 horas, com emprego de nitrato como receptor de elétrons: $(\circ) \mathrm{RI} 1 ;(\square) \mathrm{RI}$; $(\Delta)$ RI3

Após cerca de 15 dias, foi realizado o segundo perfil temporal. Os resultados das análises, referentes à RI1, RI2 e RI3, podem ser visualizados nas Figuras 39, 40 e 41, respectivamente. 


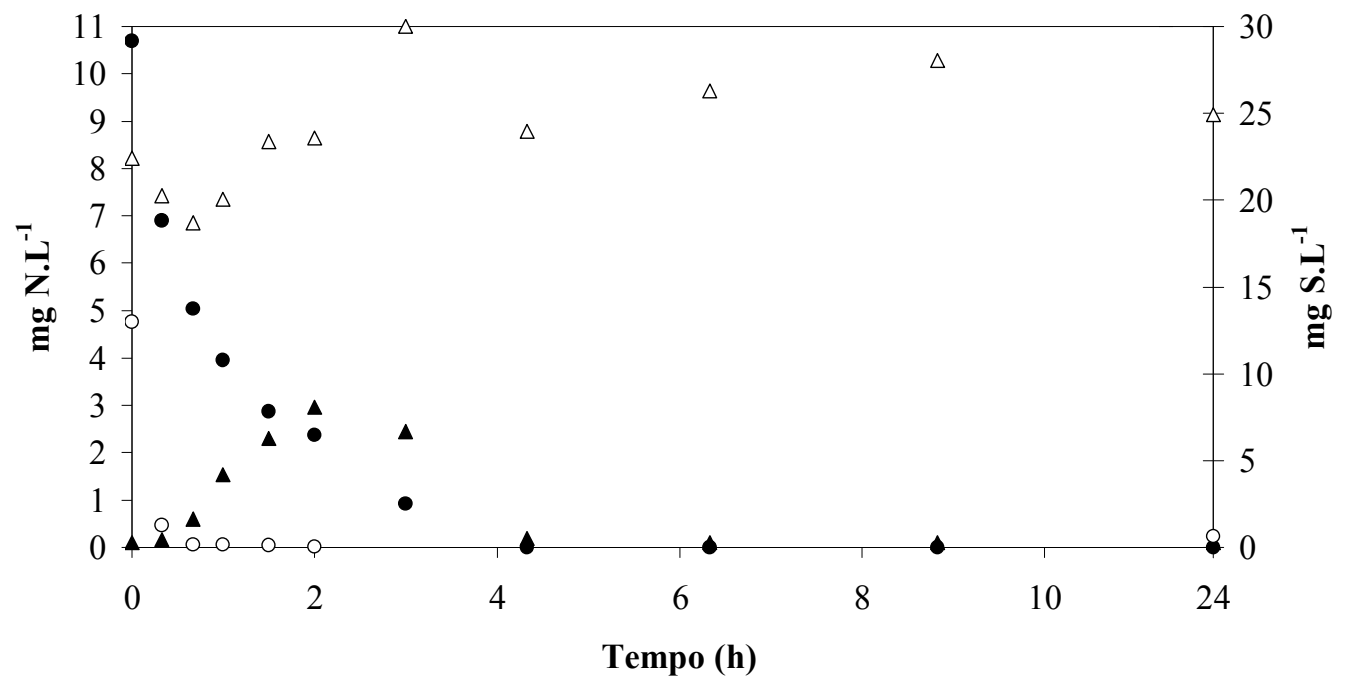

Figura 39 - Segundo perfil temporal dos parâmetros durante um ciclo de 24 horas, com emprego de nitrato como receptor de elétrons, em RI1 (segunda fase): $(\bullet) \mathrm{N}^{-N_{3}}{ }_{3}^{-} ;(\boldsymbol{\Delta}) \mathrm{N}^{-\mathrm{NO}_{2}}{ }^{-}$; (०) SDT; $(\Delta) \mathrm{S}-$ $\mathrm{SO}_{4}{ }^{2-}$

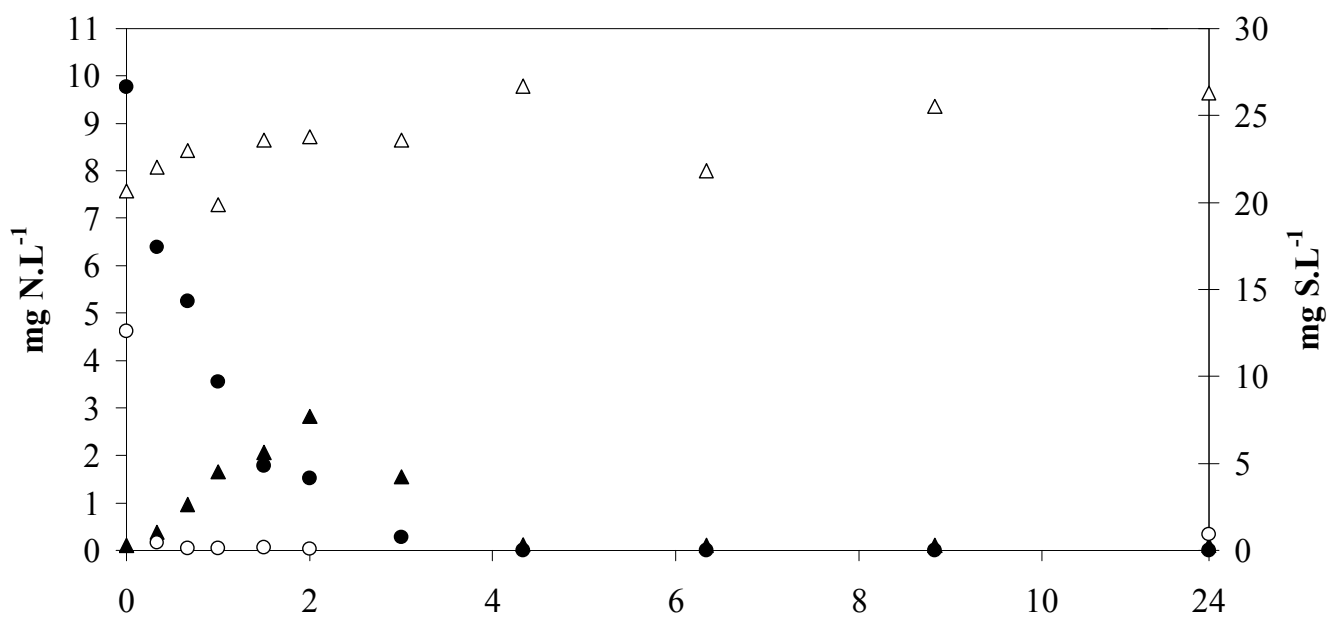

Tempo (h)

Figura 40 - Segundo perfil temporal dos parâmetros durante um ciclo de 24 horas, com emprego de nitrato como receptor de elétrons, em RI2 (segunda fase): $(\bullet) \mathrm{N}^{-N^{-}}{ }_{3}^{-} ;(\boldsymbol{\Delta}) \mathrm{N}^{-\mathrm{NO}_{2}}{ }^{-} ;(\circ) \mathrm{SDT} ;(\Delta) \mathrm{S}-$ $\mathrm{SO}_{4}{ }^{2-}$

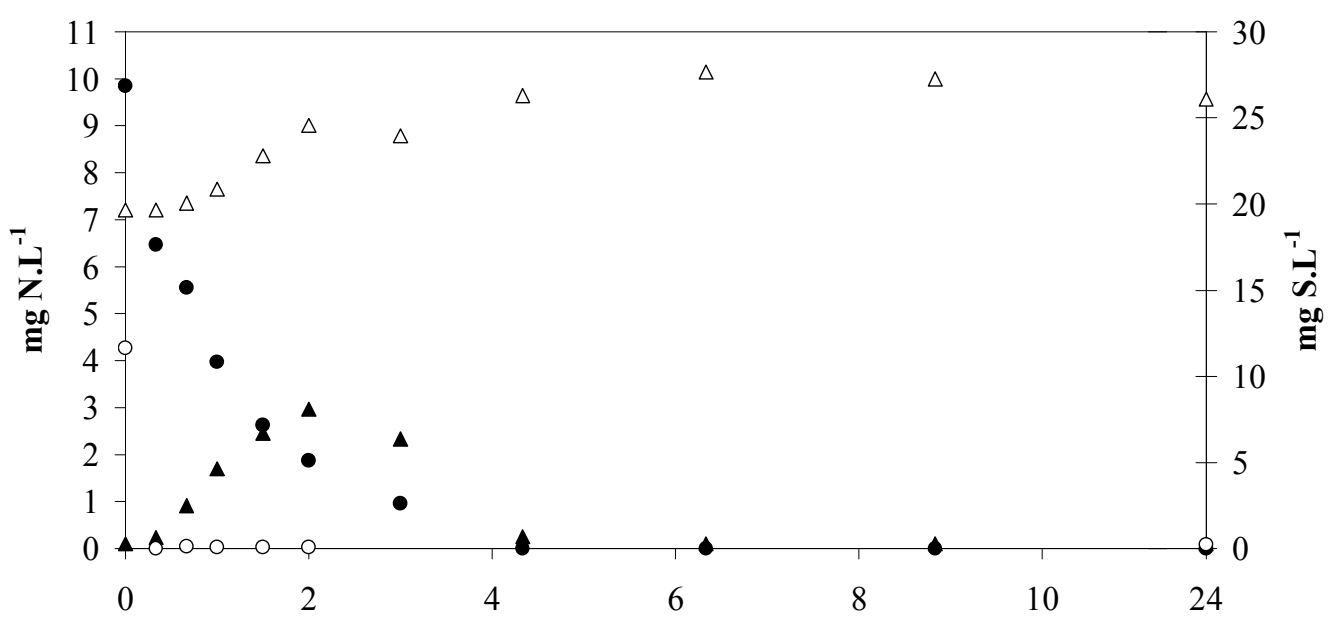

Tempo (h)

Figura 41 - Segundo perfil temporal dos parâmetros durante um ciclo de 24 horas, com emprego de nitrato como receptor de elétrons, em RI3 (segunda fase): $(\bullet) \mathrm{N}^{-N^{-}}{ }_{3}^{-} ;(\boldsymbol{\Delta}) \mathrm{N}_{-} \mathrm{NO}_{2}^{-} ;(\circ) \mathrm{SDT} ;(\Delta) \mathrm{S}-$ $\mathrm{SO}_{4}{ }^{2-}$ 
Os resultados obtidos foram semelhantes àqueles do primeiro perfil: a desnitrificação completa ocorreu após 4 horas, enquanto o consumo total de sulfeto foi detectado logo na primeira hora. A produção de sulfato também foi muito inferior à concentração teórica relacionada à oxidação do sulfeto injetado. Também houve geração de nitrito em torno de 2 horas, com consumo subseqüente; neste caso, a concentração de nitrito formado foi ligeiramente maior que no perfil anterior. Neste perfil, foi mantida a hipótese de existência de fontes adicionais de elétrons para a redução de nitrato e nitrito associada à desnitrificação com aplicação de sulfeto.

Os dados da variação temporal da DQO total, apresentados na Figura 42, revelaram comportamento semelhante ao perfil anterior: aumento da concentração da DQO nas primeiras 2 horas, com subseqüente redução, e as concentrações ao início e final do ciclo foram muito próximas ou com pequeno decréscimo ao final.

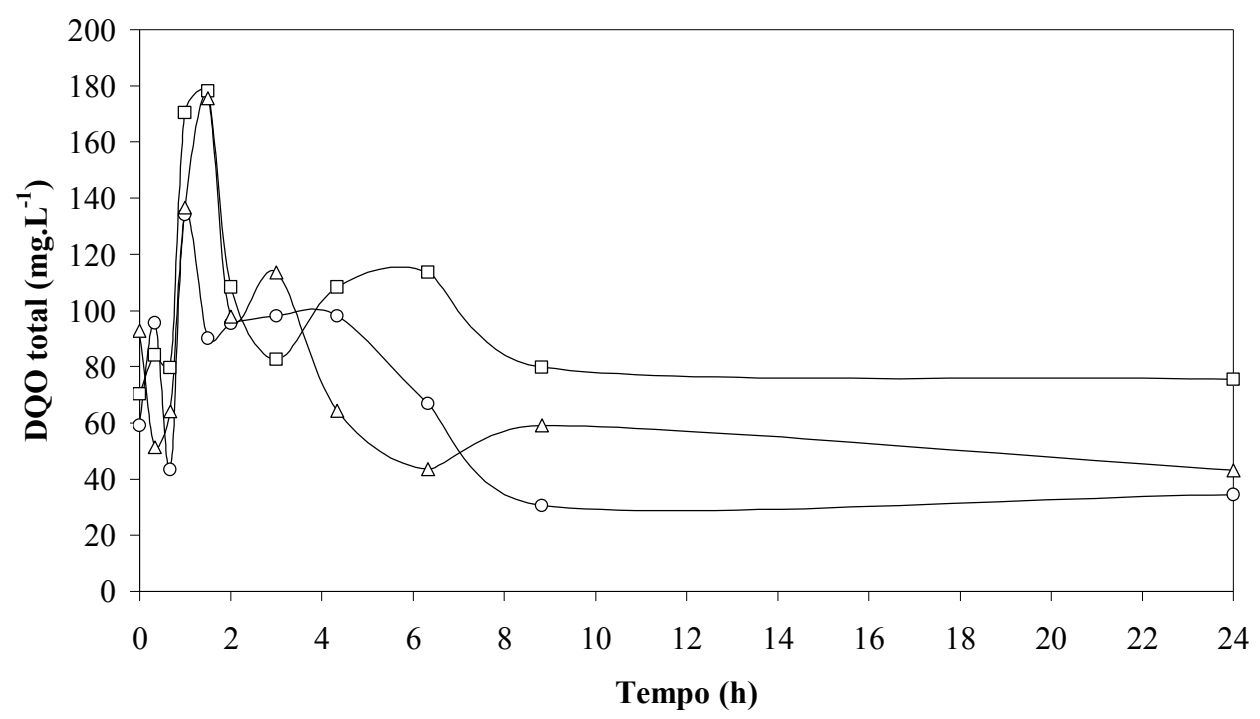

Figura 42 - Segundo perfil temporal da DQO total durante um ciclo de 24 horas, com emprego de nitrato como receptor de elétrons: $(\circ)$ RI1; $(\square)$ RI2; $(\Delta)$ RI3 


\subsection{AJUSTES DE MODELOS CINÉTICOS}

Os ajustes de modelos cinéticos foram realizados com base nos valores relativos ao consumo de nitrogênio, obtidos nos perfis temporais, em relação à quantidade de biomassa presente no interior dos frascos. A seguir, será descrita a determinação de parâmetros utilizados na análise dos fenômenos de transferência de massa, além de serem detalhados os modelos cinéticos ajustados na primeira e segunda fase da pesquisa.

\subsubsection{Parâmetros utilizados na análise dos fenômenos de transferência de massa}

A difusividade efetiva do substrato na biopartícula $\left(D_{e}\right)$, utilizada na equação (16), foi determinada com base em uma regra proposta por Droste e Kennedy (1986), a qual considera a difusividade de um substrato em biofilmes anaeróbios como sendo $80 \%$ do valor da difusão do substrato em água. A difusividade do nitrogênio em solução aquosa à $25^{\circ} \mathrm{C}$ e $1 \mathrm{~atm}\left(D_{L}\right)$, segundo Perry e Chilton (1985), corresponde a $1,99 \cdot 10^{-5} \mathrm{~cm}^{2} \cdot \mathrm{s}^{-1}$. Sendo assim, a difusividade considerada nos cálculos foi equivalente a $1,592 \cdot 10^{-5} \mathrm{~cm}^{2} \cdot \mathrm{s}^{-1}$.

A viscosidade do líquido, utilizada nas equações (19) e (20), correspondeu a $1,0037 \cdot 10^{-2} \mathrm{~cm}^{2} \cdot \mathrm{s}^{-1}$ a $22^{\circ} \mathrm{C}$, segundo Perry e Chilton (1985), e a porosidade do leito foi baseada em Zaiat et al. (1997), correspondente a 0,4.

O valor do número de Sherwood (equação 18) foi obtido igualando-se as equações (17) e (21), e substituindo o valor de $S c$, obtido pela equação (19), e de $\varepsilon$, conforme demonstrado a seguir:

$$
\begin{gathered}
S h \cdot\left(\mathrm{S}_{\mathrm{c}}\right)^{-1 / 3} \cdot\left(\mathrm{Re}_{\mathrm{p}}^{*}\right)^{-1}=\frac{1.09 \cdot\left(\mathrm{Re}_{\mathrm{p}}^{*}\right)^{-1}}{\varepsilon} \\
S h=\frac{1,09 \cdot(504,37)^{1 / 3}}{0,4}
\end{gathered}
$$




$$
\therefore S h=21,69
$$

Rearranjando a equação (18) em função de $k_{s}$, e substituindo os valores de $d_{p}, D_{L}$ e $S h$, finalmente, foi possível encontrar, empiricamente, o coeficiente de transferência de massa, o qual resultou em $4,32 \cdot 10^{-4} \mathrm{~cm} \cdot \mathrm{s}^{-1}$.

\subsubsection{Primeira fase - nitrato como receptor de elétrons}

O modelo cinético de primeira ordem ajustou-se melhor aos pontos obtidos no primeiro perfil, conforme demonstrado na Figura 43. Deve-se considerar que este comportamento foi influenciado pelos fenômenos de transferência de massa, fato que será detalhado posteriormente. A resistência à transferência de massa é mais significativa para sistemas nos quais existe a formação de biofilme, como é o caso da biomassa imobilizada em espuma de poliuretano. Além disso, o consumo completo do substrato, neste caso nitrogênio, é indicativo de que o modelo cinético é de ordem zero.

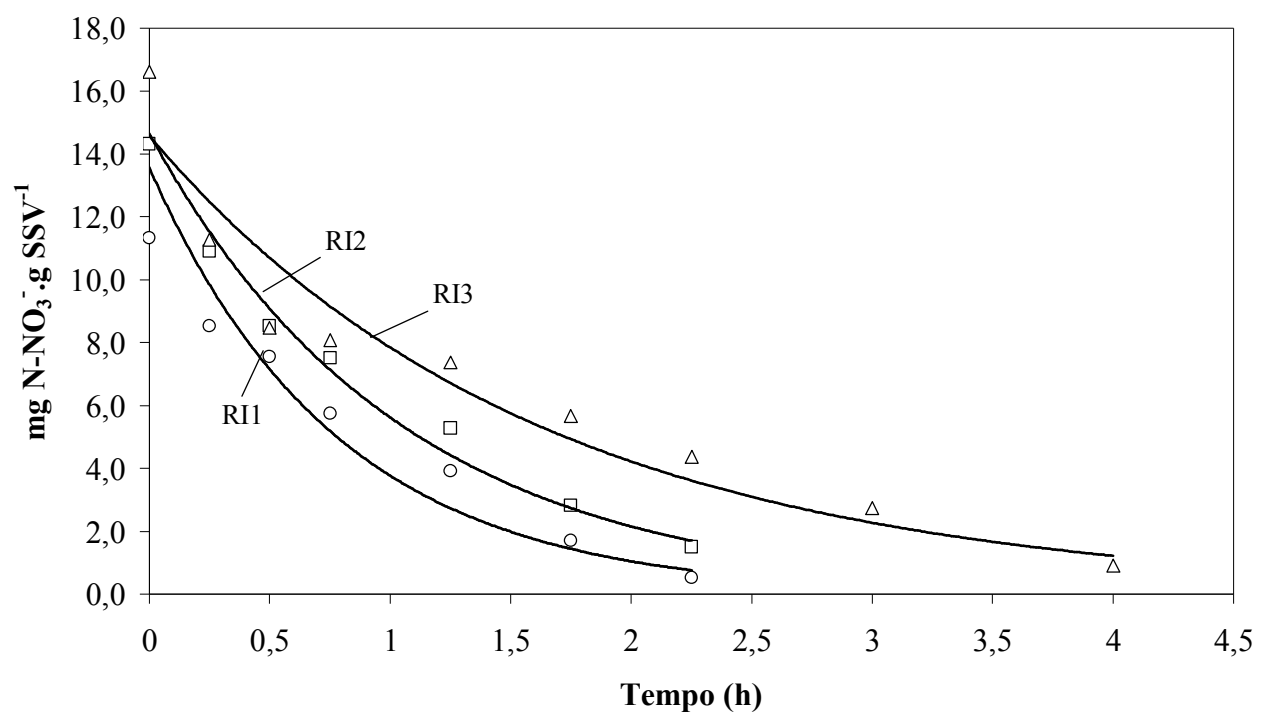

Figura 43 - Ajustes de modelos cinéticos considerando reação de primeira ordem para remoção de nitrato (primeiro perfil): (०) RI1; ( $\square)$ RI2; $(\Delta)$ RI3 
Os valores obtidos para as constantes cinéticas de primeira ordem e os respectivos coeficientes de correlação, referentes à RI1, RI2 e RI3, foram $1,093 \mathrm{~h}^{-1}\left(\mathrm{R}^{2}=0,95\right), 1,106 \mathrm{~h}^{-1}$ $\left(\mathrm{R}^{2}=0,99\right)$ e $0,799 \mathrm{~h}^{-1}\left(\mathrm{R}^{2}=0,95\right)$, respectivamente. Observa-se que as curvas ajustadas de RI1 e RI2 tiveram maior reprodutibilidade, sendo obtidos valores muito próximos da constante cinética. Nestes reatores, o decaimento da concentração de nitrato foi mais rápido quando comparado com RI3, como pode ser observado pelos maiores valores da constante cinética.

A partir dos ajustes de modelos cinéticos, foram determinadas as velocidades específicas de remoção de nitrato ao longo do ciclo, conforme ilustrado na Figura 44.

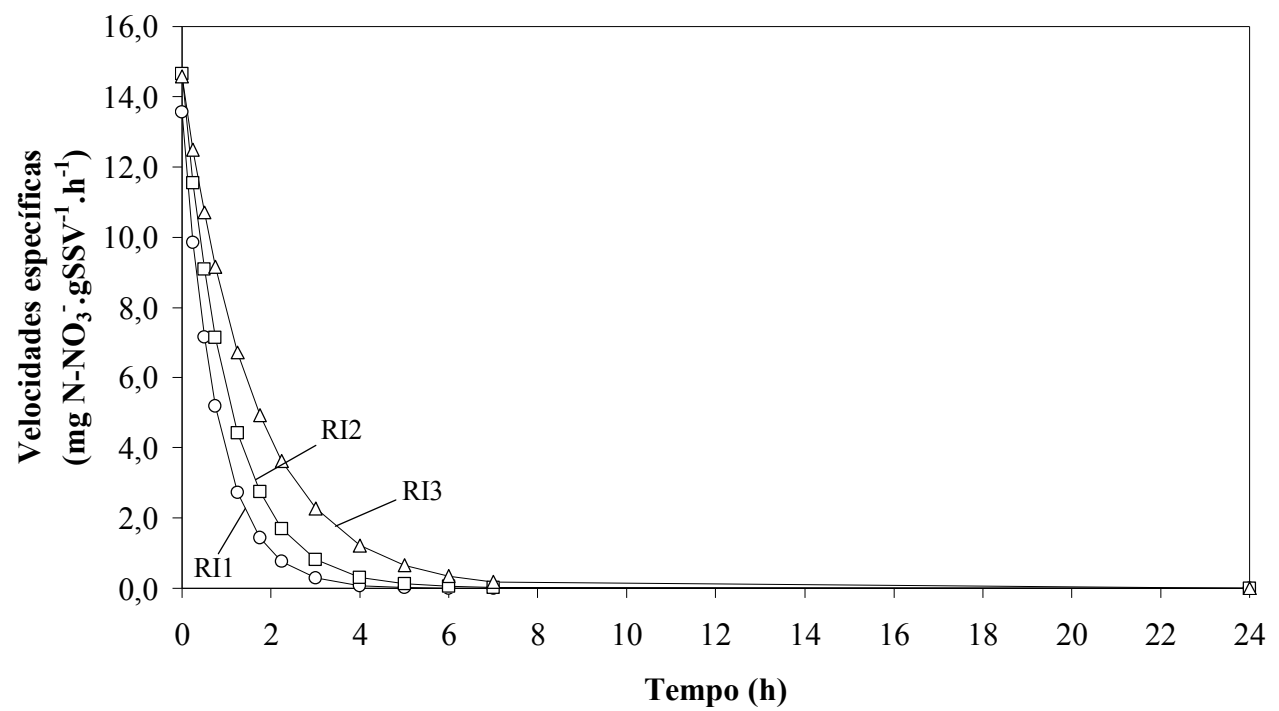

Figura 44 - Velocidades específicas de remoção de nitrato (primeiro perfil): (०) RI1; ( $\square)$ RI2; ( $\Delta$ ) RI3

As máximas velocidades específicas de remoção de nitrato encontradas foram 13,6 mgN.gSSV ${ }^{-1} \cdot h^{-1}$ para RI1, 14,7 mgN.gSSV ${ }^{-1} \cdot h^{-1}$ para RI2 e $14,6 \mathrm{mgN} \cdot \mathrm{gSSV}^{-1} \cdot \mathrm{h}^{-1}$ para RI3. Tais valores são superiores aos resultados encontrados por Beristain-Cardoso et al. (2006), os quais obtiveram velocidade específica de consumo de nitrato de $2,1 \mathrm{mgN} \cdot \mathrm{gSSV}^{-1} \cdot \mathrm{h}^{-1}$. Estes autores realizaram ensaios cinéticos empregando biomassa suspensa, previamente enriquecida em reator UASB de 2 L, inoculado com lodo metanogênico proveniente de indústria de papel, e alimentado com tiossulfato e nitrato a altas concentrações. 
Reyes-Avila et al. (2004) obtiveram velocidade específica de remoção de nitrato, com aplicação de sulfeto como doador de elétrons, em torno de $16 \mathrm{mgN} \cdot \mathrm{gSSV}^{-1} \cdot \mathrm{h}^{-1}$, valor ligeiramente superior aos encontrados nesta pesquisa. Os autores realizaram ensaios cinéticos em reator contínuo de 1,3 L, com agitação constante, empregando biomassa suspensa, proveniente de reator desnitrificante heterotrófico adaptado à desnitrificação autotrófica por meio da aplicação contínua de sulfeto. A relação $\mathrm{N} / \mathrm{S}$ mantida foi equivalente à estequiométrica.

Entretanto, as velocidades referentes à desnitrificação heterotrófica são, de maneira geral, superiores quando comparados à desnitrificação autotrófica. No mesmo trabalho supracitado, Reyes-Avila et al. (2004) obtiveram velocidade de desnitrificação utilizando acetato como doador de elétrons próxima de $80 \mathrm{mgN} \cdot \mathrm{gSSV}^{-1} \cdot \mathrm{h}^{-1}$.

Para avaliar a magnitude dos efeitos da resistência à transferência de massa, foram calculados os parâmetros adimensionais número de Biot $(B i)$, módulo de Thiele observado $\left(\phi_{o b s}\right)$, e fator de efetividades $(\eta)$ os quais podem ser visualizados na Tabela 9 para os três reatores.

Tabela 9 - Parâmetros adimensionais para avaliação da magnitude dos efeitos de transferência de massa, para os três reatores estudados, relativos ao primeiro perfil temporal empregando nitrato como receptor de elétrons.

\begin{tabular}{cccc}
\hline & \multicolumn{3}{c}{ Parâmetros adimensionais } \\
\cline { 2 - 4 } Reatores & $\boldsymbol{B i}$ & $\phi_{\text {obs }}$ & $\boldsymbol{\eta}$ \\
\hline RI1 & 13,57 & 0,580 & 0,799 \\
RI2 & 13,57 & 0,496 & 0,847 \\
RI3 & 13,57 & 0,425 & 0,888 \\
\hline
\end{tabular}

Os efeitos significativos da resistência à transferência de massa externa foram comprovados por meio dos valores obtidos para $B i$, os quais foram inferiores a 100 . Sendo assim, a velocidade de transferência no filme externo foi limitante no processo. Para que tal 
resistência fosse minimizada, a agitação dos reatores poderia ser aumentada; entretanto, haveria desprendimento da biomassa aderida na espuma. A condição de minimização da resistência externa à transferência de massa, obtida por Vieira (1996), foi estabelecida com velocidade rotacional de $150 \mathrm{rpm}$, havendo desprendimento completo da biomassa aderida nas matrizes de espuma de poliuretano.

Os valores encontrados para $\phi_{o b s}$ (superiores a 0,3 ), para os três ensaios, comprovam que os efeitos da resistência à transferência de massa interna também foram significativos, ou seja, a velocidade de reação observada foi limitada pela difusão intraparticular.

Para complementar esta análise, os valores de $\eta$, menores que a unidade, reforçam o fato de que as resistências externa e intraparticular à transferência de massa foram significativas nas condições operacionais utilizadas.

Desse modo, os parâmetros cinéticos encontrados anteriormente são aparentes, pois envolvem, além do processo de conversão, os processos físicos de transferência, isto é, as limitações por transferência de massa. Além disso, existe a possibilidade de o modelo cinético de primeira ordem não ser adequado ao sistema analisado, visto que houve forte influência dos fenômenos de transferência de massa, além da ocorrência da desnitrificação completa, ou seja, consumo completo do substrato, fato que é característico de modelos cinéticos de ordem zero.

O segundo perfil foi realizado após o choque térmico, fato que proporcionou a descaracterização do ajuste de primeira ordem. Neste caso, o modelo de ordem zero foi mais bem ajustado aos dados de concentração de nitrato (Figura 45), com baixos coeficientes de correlação. 


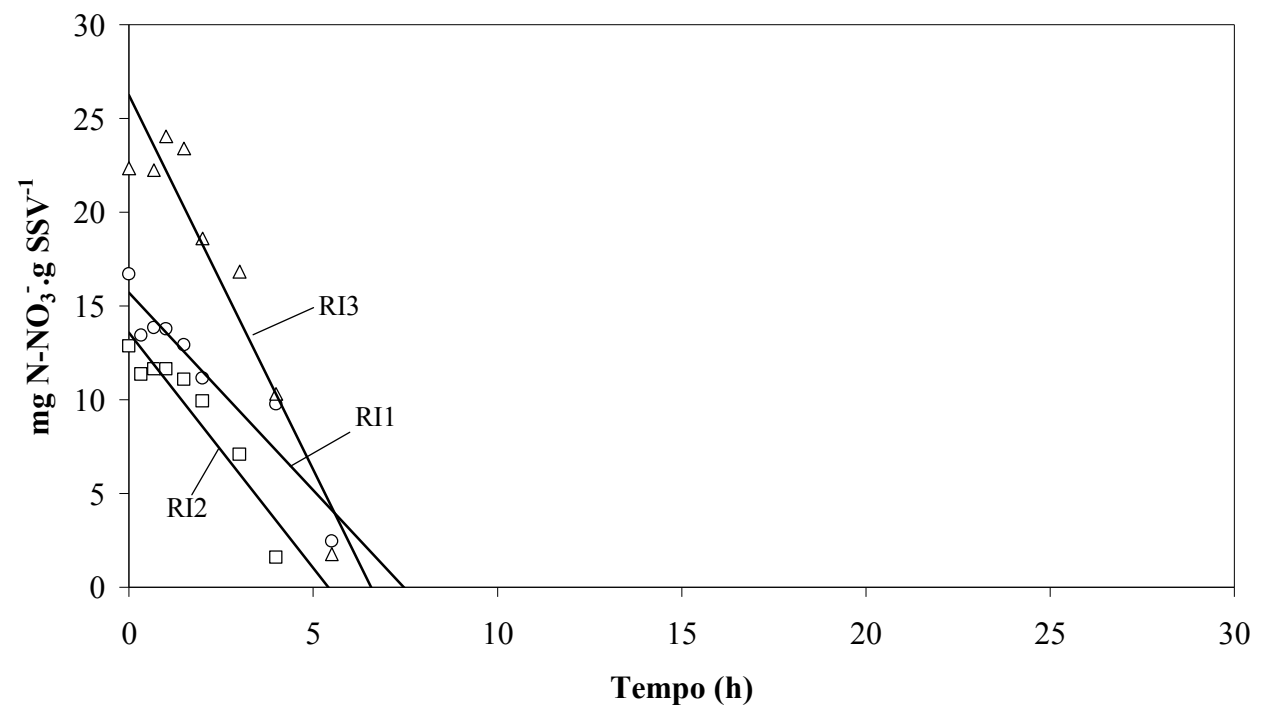

Figura 45 - Ajustes de modelos cinéticos considerando reação de ordem zero para remoção de nitrato (segundo perfil): (०) RI1; ( $\square)$ RI2; ( $\Delta$ ) RI3

Os valores obtidos para as constantes cinéticas de ordem zero e os respectivos coeficientes de correlação, referentes à RI1, RI2 e RI3, foram $2,11 \mathrm{mgN} \cdot \mathrm{gSSV}^{-1} \cdot \mathrm{h}^{-1}\left(\mathrm{R}^{2}=\right.$ $0,90), 2,51 \mathrm{mgN} \cdot g \mathrm{gSV}^{-1} \cdot \mathrm{h}^{-1}\left(\mathrm{R}^{2}=0,88\right)$ e $3,99 \mathrm{mgN} \cdot \mathrm{gSSV}^{-1} \cdot \mathrm{h}^{-1}\left(\mathrm{R}^{2}=0,90\right)$, respectivamente.

Neste caso, as limitações impostas pela transferência de massa intraparticular foram desprezíveis, ao contrário da resistência externa à transferência de massa, conforme observado na Tabela 10. Pode-se inferir que, de alguma forma, o aquecimento promoveu a minimização da resistência interna à transferência de massa, e por isso, o modelo cinético ajustado foi de ordem zero, diferentemente daquele obtido no perfil anterior. Este fato é um indicativo de que a resistência intraparticular teve influência mais efetiva sobre os modelos cinéticos relacionados às reações bioquímicas do que a resistência externa à transferência de massa. 
Tabela 10 - Parâmetros adimensionais para avaliação da magnitude dos efeitos de transferência de massa, para os três reatores estudados, relativos ao segundo perfil temporal empregando nitrato como receptor de elétrons.

\begin{tabular}{ccc}
\hline & \multicolumn{2}{c}{ Parâmetros adimensionais } \\
\cline { 2 - 3 } Reatores & Número de Biot $(B i)$ & Módulo de Thiele $\left(\phi_{o b s}\right)$ \\
\hline RI1 & 13,57 & 0,0611 \\
RI2 & 13,57 & 0,0944 \\
RI3 & 13,57 & 0,0866 \\
\hline
\end{tabular}

\subsubsection{Primeira fase - nitrito como receptor de elétrons}

Do mesmo modo que no primeiro perfil empregando nitrato como receptor de elétrons, o modelo cinético de primeira ordem ajustou-se mais adequadamente aos pontos obtidos no ensaio com aplicação de nitrito, conforme apresentado na Figura 46. Entretanto, os parâmetros cinéticos encontrados revelam que o consumo de nitrito ocorreu de forma mais lenta do que o consumo de nitrato. Neste ensaio, as constantes cinéticas de primeira ordem e os respectivos coeficientes de correlação, referentes à RI1, RI2 e RI3, foram $0,368 \mathrm{~h}^{-1}\left(\mathrm{R}^{2}=\right.$ $0,97), 0,124 \mathrm{~h}^{-1}\left(\mathrm{R}^{2}=0,98\right)$ e $0,301 \mathrm{~h}^{-1}\left(\mathrm{R}^{2}=0,97\right)$, respectivamente. O consumo mais lento de nitrito, quando comparado ao de nitrato, contraria afirmação feita por Krishna e Philip (2005) e Mahmood et al. (2007), que atestam a maior reatividade do nitrito, proporcionando consumo mais rápido de nitrogênio quando este receptor de elétrons é aplicado. 


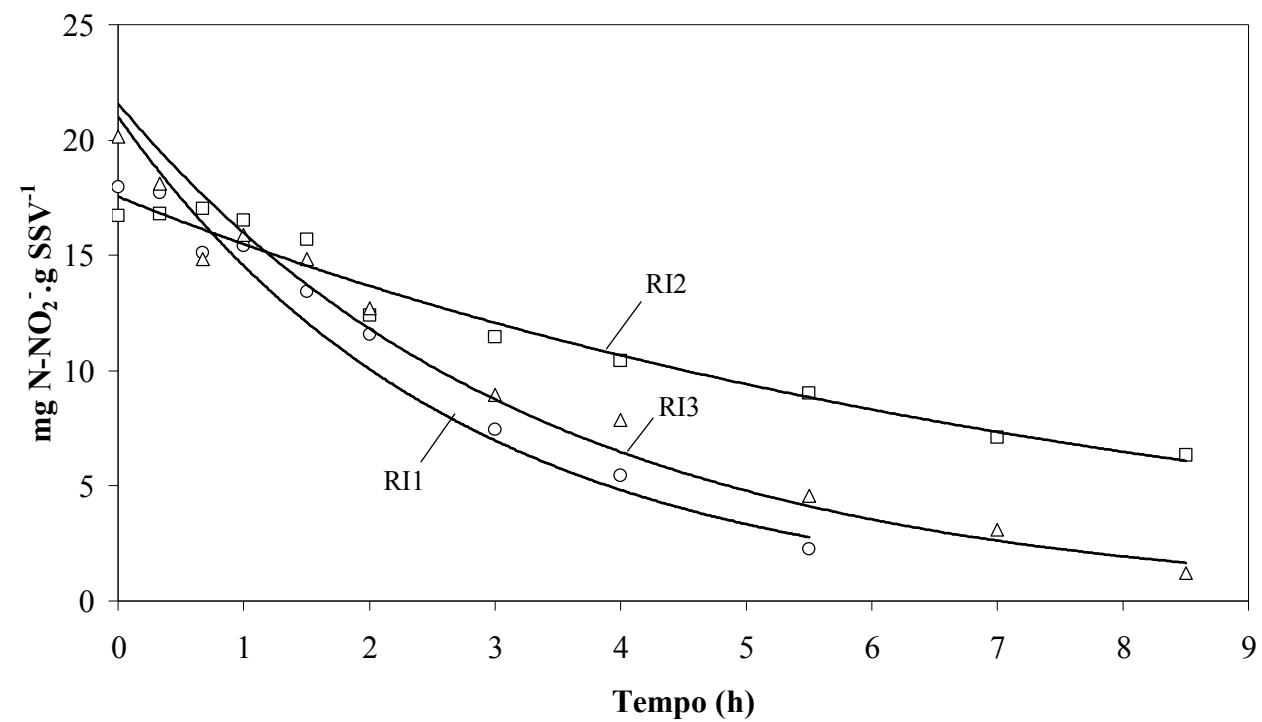

Figura 46 - Ajustes de modelos cinéticos considerando reação de primeira ordem para remoção de nitrito: (०) RI1; (口) RI2; ( $\Delta$ ) RI3

A partir dos ajustes de modelos cinéticos, foram determinadas as velocidades específicas de remoção de nitrito ao longo do ciclo, conforme ilustrado na Figura 47.

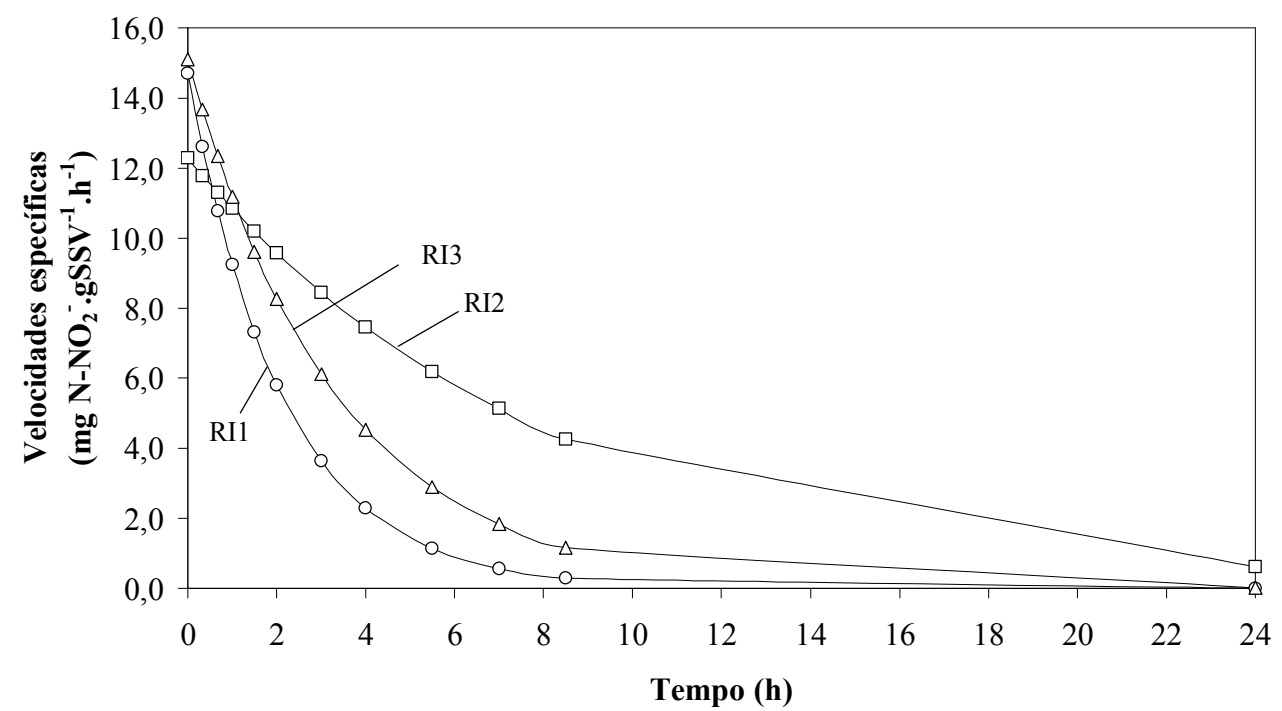

Figura 47 - Velocidades específicas de remoção de nitrito: (o) RI1; ( $\square)$ RI2; ( $\Delta$ ) RI3

As máximas velocidades específicas de remoção de nitrito encontradas foram 14,7 $\operatorname{mgN} . \mathrm{gSSV}^{-1} \cdot \mathrm{h}^{-1}$ para RI1, $12,3 \mathrm{mgN} \cdot \mathrm{gSSV}^{-1} \cdot \mathrm{h}^{-1}$ para RI2 e $15,0 \mathrm{mgN} \cdot \mathrm{gSSV}^{-1} \cdot \mathrm{h}^{-1}$ para RI3. Estes valores aproximaram-se bastante daqueles obtidos com aplicação de nitrato. 
Pérez et al. (2007) obtiveram maior velocidade máxima específica de consumo de nitrito, equivalente a $32 \mathrm{mgN} \cdot \mathrm{gSSV}^{-1} \cdot \mathrm{h}^{-1}$. Os autores utilizaram reator operado em batelada seqüencial (RBS) com aeração intermitente, e volume de 3,5 L, contendo biomassa suspensa heterotrófica desnitrificante adaptada à desnitrificação autotrófica, para o pós-tratamento de efluente de digestor de lodo de esgoto sanitário. Este fato possivelmente foi devido à maior concentração de nitrogênio amoniacal $\left(700-800 \mathrm{mg} \mathrm{NH}_{4}{ }^{+} \cdot \mathrm{L}^{-1}\right)$ presente na água residuária a ser tratada no referido trabalho, que era convertido às formas oxidadas de nitrogênio nos períodos aerados para a ocorrência da desnitrificação autotrófica nos períodos anóxicos.

Quando comparados à desnitrificação heterotrófica via nitrito, as velocidades específicas de desnitrificação autotrófica via nitrito encontradas na presente pesquisa são muito inferiores. Chung e Bae (2002) obtiveram velocidades específicas de desnitrificação heterotrófica utilizando glicose como doador de elétrons entre 31,7 e $66,3 \mathrm{mgN} \cdot \mathrm{gSSV}^{-1} \cdot \mathrm{h}^{-1}$ para nitrito como receptor de elétrons. Os autores operaram reator em batelada seqüencial de $1 \mathrm{~L}$, inoculado com biomassa suspensa desnitrificante, previamente adaptada ao processo.

A modelação cinética relativa às reações bioquímicas sofreu influência efetiva dos fenômenos de transferência de massa, sendo as resistências externas e internas significativas, como pode ser observado pelos valores dos parâmetros adimensionais da Tabela 11.

Tabela 11 - Parâmetros adimensionais para avaliação da magnitude dos efeitos de transferência de massa, para os três reatores estudados, relativos ao perfil temporal empregando nitrito como receptor de elétrons.

\begin{tabular}{cccc}
\hline & \multicolumn{3}{c}{ Parâmetros adimensionais } \\
\cline { 2 - 4 } Reatores & $\boldsymbol{B i}$ & $\phi_{\text {obs }}$ & $\boldsymbol{\eta}$ \\
\hline RI1 & 13,57 & 0,397 & 0,904 \\
RI2 & 13,57 & 0,356 & 0,927 \\
RI3 & 13,57 & 0,363 & 0,923 \\
\hline
\end{tabular}



ao tratamento de esgoto sanitário

Portanto, a velocidade de remoção de nitrogênio, via nitrito, foi limitada pela camada de líquido estagnada ao redor das partículas e pela velocidade de difusão intraparticular. Neste caso, os parâmetros cinéticos obtidos com base nas reações bioquímicas foram aparentes, em função de as condições experimentais utilizadas não possibilitarem a minimização das resistências de transferência de massa.

\subsubsection{Segunda fase - nitrato como receptor de elétrons}

Na segunda fase deste trabalho, os ajustes de modelos cinéticos realizados com base nos valores relativos ao consumo de nitrogênio, obtidos nos perfis temporais, também consideraram a quantidade de biomassa presente nos reatores. Para isso, o teor de SSV presente no efluente de reator anaeróbio tratando água residuária de abatedouro de aves, utilizado na alimentação, foi descontado do valor de SSV medido experimentalmente para cada reator. Desse modo, foi possível obter parâmetros cinéticos específicos da mesma forma que na primeira fase.

A cinética de primeira ordem com relação à remoção de nitrato foi a mais adequada para o ajuste dos dados, em ambos os perfis realizados, como pode ser visualizado nas Figuras 48 e 49. As constantes cinéticas de primeira ordem e os respectivos coeficientes de correlação, referentes ao primeiro perfil, foram: $0,795 \mathrm{~h}^{-1}\left(\mathrm{R}^{2}=0,99\right)$ para $\mathrm{RI} 1 ; 0,737 \mathrm{~h}^{-1}\left(\mathrm{R}^{2}\right.$ $=0,95)$ para RI2; e $0,859 \mathrm{~h}^{-1}\left(\mathrm{R}^{2}=0,95\right)$ para RI3. Os valores das constantes cinéticas determinadas no segundo perfil foram, de modo geral, bastante similares a estes: $0,759 \mathrm{~h}^{-1}\left(\mathrm{R}^{2}\right.$ $=0,98)$ para $\mathrm{RI} 1 ; 1,138 \mathrm{~h}^{-1}\left(\mathrm{R}^{2}=0,98\right)$ para $\mathrm{RI} 2$; e $0,765 \mathrm{~h}^{-1}\left(\mathrm{R}^{2}=0,99\right)$ para RI3. 


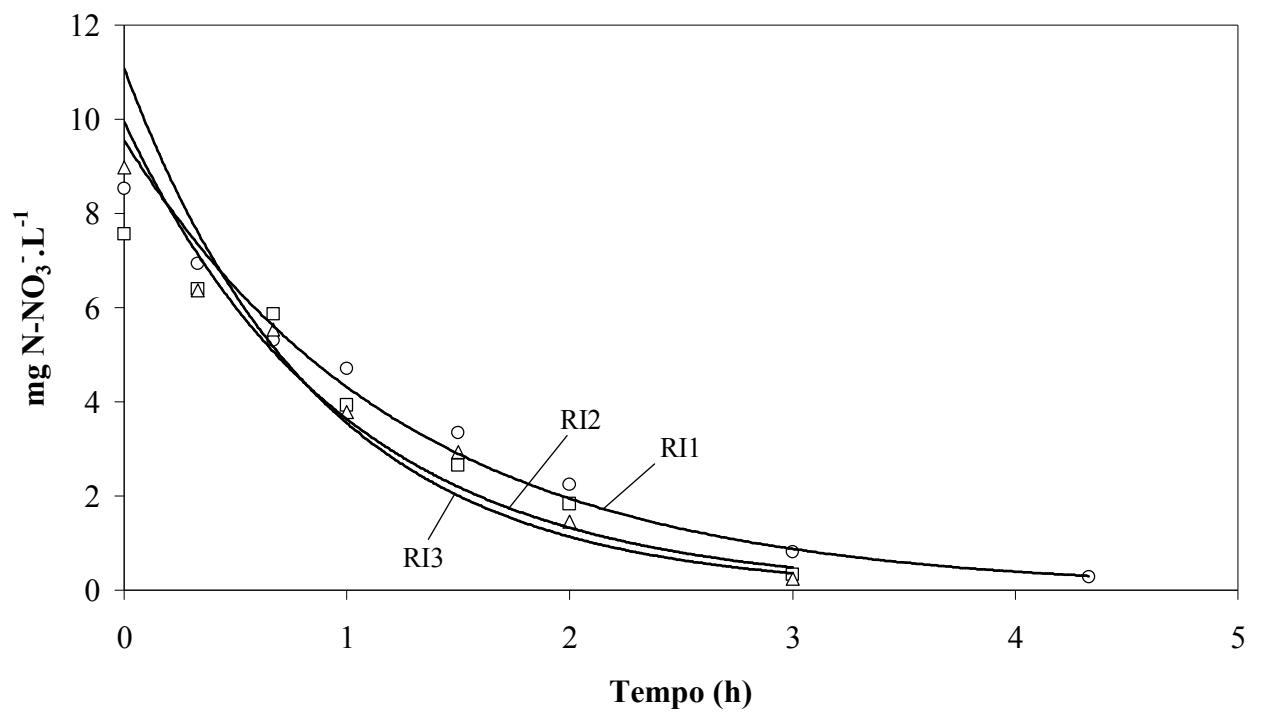

Figura 48 - Ajustes de modelos cinéticos considerando reação de primeira ordem para remoção de nitrato (primeiro perfil da segunda fase): (०) RI1; ( $\square)$ RI2; ( $\Delta$ ) RI3

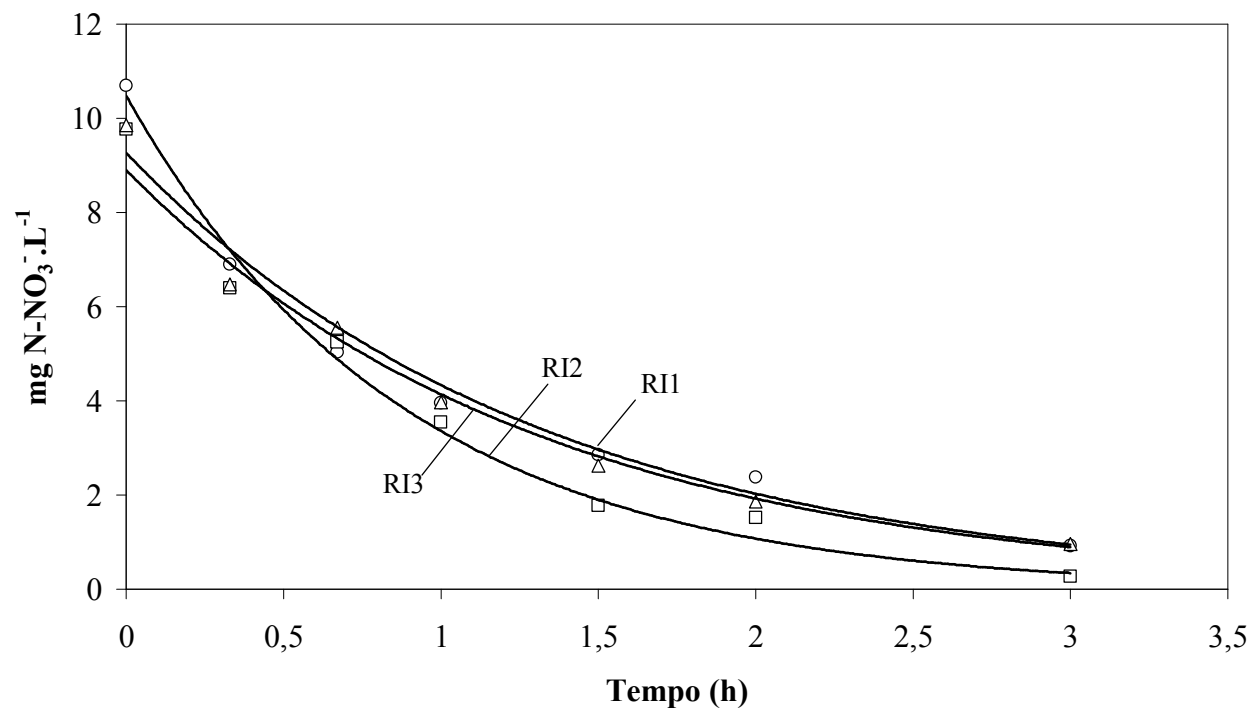

Figura 49 - Ajustes de modelos cinéticos considerando reação de primeira ordem para remoção de nitrato (segundo perfil da segunda fase): (०) RI1; ( $\square)$ RI2; ( $\Delta$ ) RI3

As velocidades específicas de remoção de nitrato foram determinadas a partir dos modelos cinéticos obtidos, conforme ilustrado nas Figuras 50 e 51, referentes ao primeiro e segundo perfis, respectivamente. As máximas velocidades encontradas, em ambos os perfis, variaram de 2 a $6 \mathrm{mg} \mathrm{N} . \mathrm{g} \mathrm{SSV}^{-1} \cdot \mathrm{h}^{-1}$, como pode ser observado na Tabela 12. 
Tabela 12 - Velocidades específicas de remoção de nitrato referentes aos experimentos realizados na segunda fase.

\begin{tabular}{cccc}
\cline { 2 - 4 } & \multicolumn{4}{c}{ Velocidades específicas de remoção de nitrato $\left(\mathbf{m g N . g S S V} \mathbf{H}^{\mathbf{1}} \cdot \mathbf{h}^{\mathbf{- 1}}\right)$} \\
\cline { 2 - 4 } & RI1 & RI2 & RI3 \\
\hline Perfil 1 & 5,93 & 2,66 & 3,75 \\
Perfil 2 & 2,17 & 2,96 & 2,43 \\
\hline
\end{tabular}

Tais valores são bastante inferiores ao encontrado por Reyes-Avila et al. (2004), os quais avaliaram a desnitrificação na presença concomitante de sulfeto e acetato, resultando em velocidade em torno de $46 \mathrm{mgN}-\mathrm{NO}_{3}{ }^{-} \cdot \mathrm{gSSV}^{-1} \cdot \mathrm{h}^{-1}$. Esta diferença pode ser explicada pela ocorrência da desnitrificação heterotrófica juntamente com a desnitrificação autotrófica, visto que o acetato é utilizado como doador orgânico de elétrons, por ser uma fonte de carbono facilmente biodegradável. No presente ensaio, a matéria orgânica presente na alimentação dificilmente seria utilizada para desnitrificação heterotrófica em função de não ser prontamente biodegradável.

Entretanto, comparando-se as velocidades encontradas com valores referentes à desnitrificação autotrófica, utilizando sulfeto como doador de elétrons, na ausência de matéria orgânica, os resultados são similares. No trabalho já citado de Beristain-Cardoso et al. (2006) a velocidade específica de remoção de nitrato foi de $2,1 \mathrm{mgN} \cdot \mathrm{gSSV}^{-1} \cdot \mathrm{h}^{-1}$. 


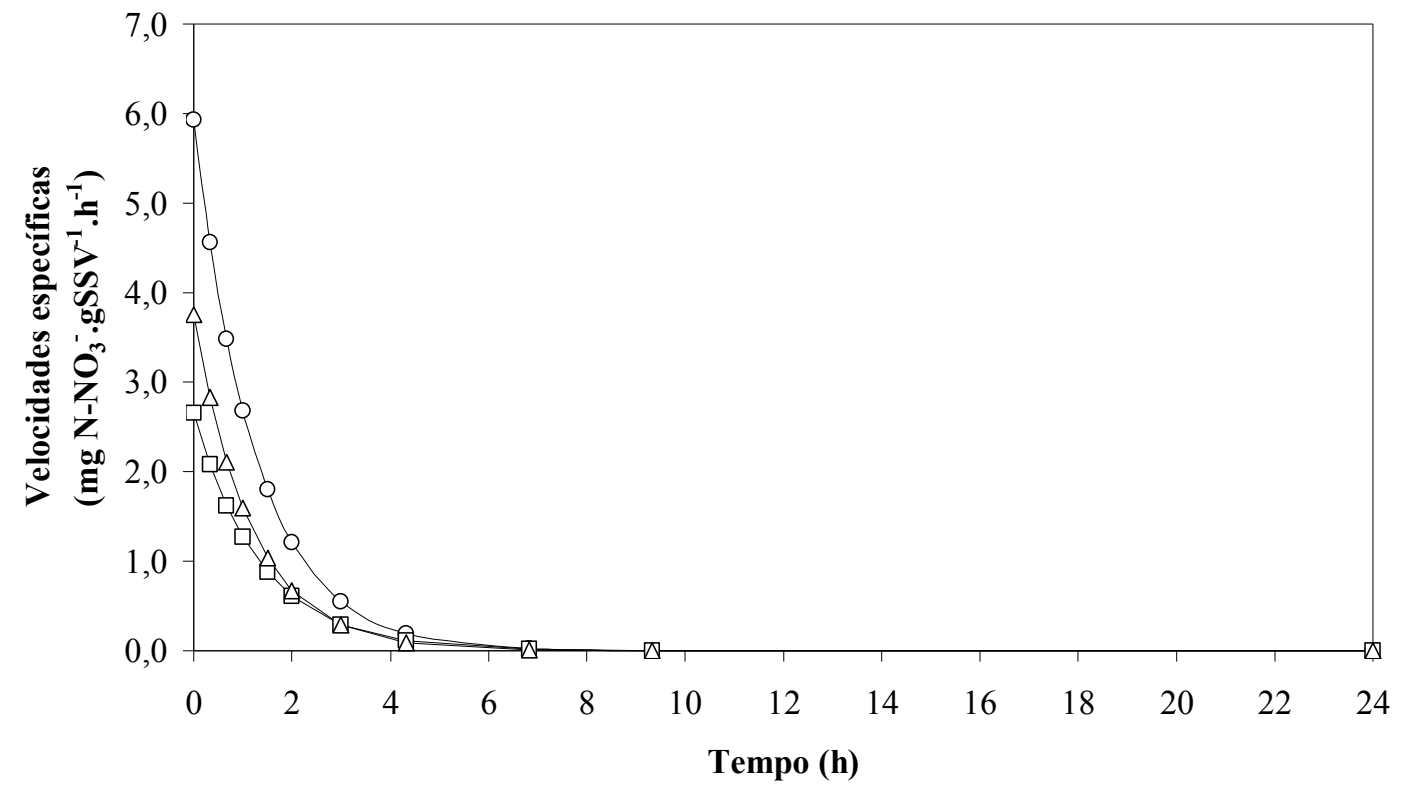

Figura 50 - Velocidades específicas de remoção de nitrato (primeiro perfil da segunda fase): (०) RI1; () RI2; ( $\Delta$ ) RI3

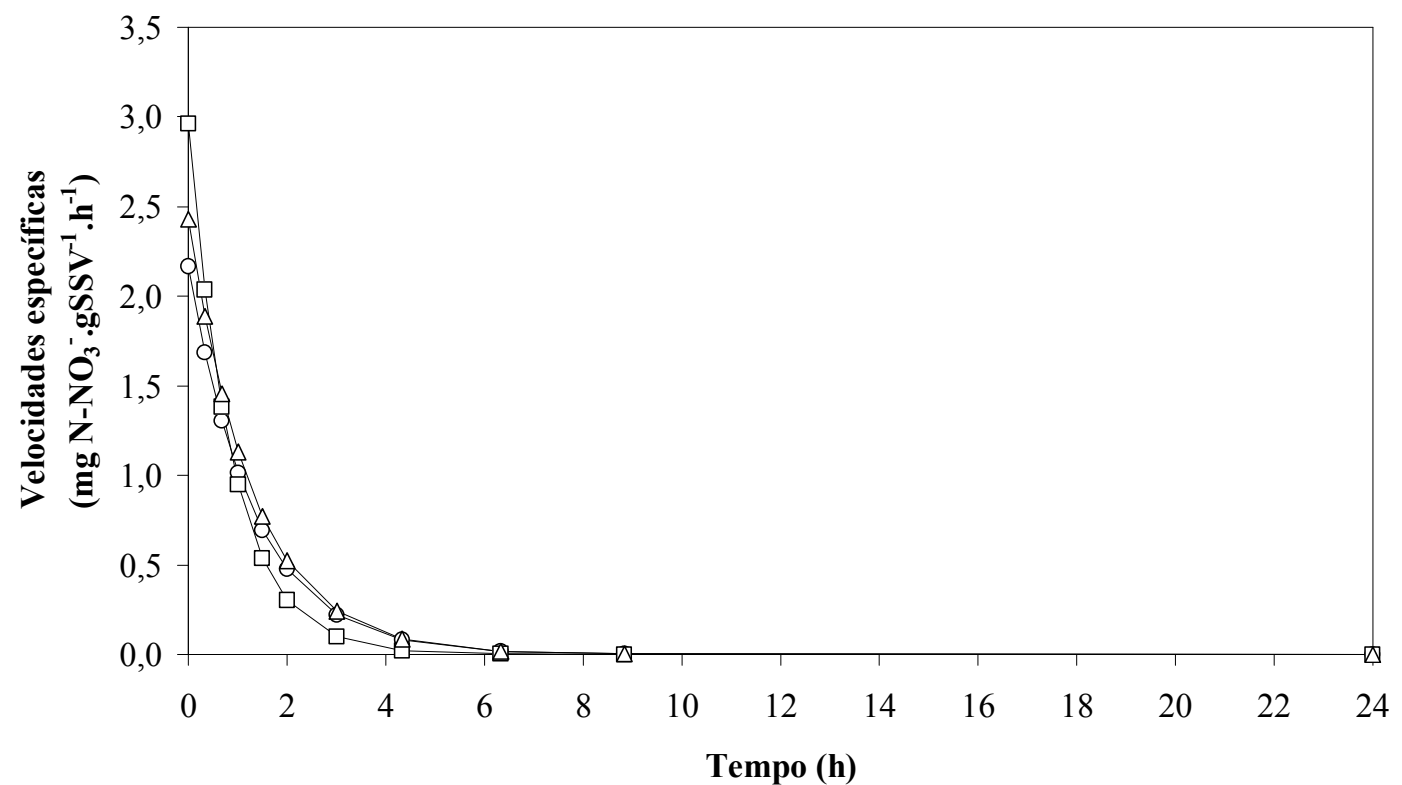

Figura 51 - Velocidades específicas de remoção de nitrato (segundo perfil da segunda fase): (०) RI1; (口) RI2; $(\Delta)$ RI3

As limitações à transferência de massa externa e interna foram significativas, conforme constatado pelos valores dos parâmetros adimensionais encontrados na Tabela 13. Desse modo, a modelagem cinética relativa às reações bioquímicas foi influenciada pelos fenômenos de transferência de massa, sendo as velocidades de transferência no filme externo e de difusão intraparticular as limitantes do processo. Conseqüentemente, os parâmetros 

ao tratamento de esgoto sanitário

cinéticos obtidos anteriormente foram aparentes, por não considerarem as resistências à transferência de massa.

Tabela 13 - Parâmetros adimensionais para avaliação da magnitude dos efeitos de transferência de massa, para os três reatores estudados, relativos ao perfil temporal empregando nitrito como receptor de elétrons.

\begin{tabular}{ccccc}
\hline & & \multicolumn{3}{c}{ Parâmetros adimensionais } \\
\cline { 3 - 5 } & Reatores & $\boldsymbol{B i}$ & $\phi_{o b s}$ & $\boldsymbol{\eta}$ \\
\hline \multirow{2}{*}{ Perfil 1 } & RI1 & 13,57 & 0,542 & 0,821 \\
& RI2 & 13,57 & 0,528 & 0,829 \\
& RI3 & 13,57 & 0,492 & 0,850 \\
\hline \multirow{2}{*}{ Perfil 2 } & RI1 & 13,57 & 0,420 & 0,891 \\
& RI2 & 13,57 & 0,520 & 0,834 \\
& RI3 & 13,57 & 0,438 & 0,881 \\
\hline
\end{tabular}

\subsection{ENSAIOS ABIÓTICOS}

Os ensaios abióticos revelaram perda de parte do sulfeto solúvel no meio líquido durante o período de um ciclo, como pode ser observado pelos dados da Tabela 14. Pequena parcela pode ter sido oxidada a sulfato em função da presença de oxigênio residual no meio líquido, como deve ter ocorrido na segunda fase. O restante do sulfeto não detectado provavelmente foi perdido para o headspace, em função do equilíbrio químico entre a fase líquida e gasosa deste composto (item 3.2.1). Com base na Lei de Henry, pode-se inferir que o sulfeto na forma gasosa foi utilizado após a solubilização no meio líquido, a qual ocorre de forma proporcional à pressão parcial do gás no headspace. Dessa forma, o sulfeto aplicado foi realmente utilizado pelos microrganismos. Além disso, os outros compostos tiveram pouca ou nenhuma alteração, especialmente o receptor de elétrons utilizado (nitrato). Desse modo, como as conversões biológicas envolveram todos os compostos analisados, o processo de 
desnitrificação autotrófica com uso de sulfeto como doador de elétrons ocorreu principalmente em função das atividades biológicas. 
Tabela 14 - Efeito das atividades químicas na desnitrificação autotrófica avaliada em reatores em batelada durante um ciclo de 24 horas.

\begin{tabular}{|c|c|c|c|c|c|c|c|c|c|c|c|c|c|c|}
\hline & \multirow[b]{2}{*}{$\mathbf{N} / \mathbf{S}$} & \multirow{2}{*}{$\begin{array}{l}\text { Adição de } \\
\text { espumas }\end{array}$} & \multicolumn{2}{|c|}{$\mathbf{p H}$} & \multicolumn{2}{|c|}{$\operatorname{mgSDT} . L^{-1}$} & \multicolumn{2}{|c|}{$\mathrm{mgS} \mathrm{SO}_{4}{ }^{2-} \cdot \mathrm{L}^{-1}$} & \multicolumn{2}{|c|}{$\mathrm{mgN}^{-\mathrm{NO}_{3}}{ }^{-} \mathbf{L}^{-1}$} & \multicolumn{2}{|c|}{$\mathrm{mgN}^{-\mathrm{NO}_{2}}{ }^{-} \mathbf{L}^{-1}$} & \multicolumn{2}{|c|}{$\operatorname{mgN}-\mathrm{NH}_{4}{ }^{+} \cdot \mathrm{L}^{-1}$} \\
\hline & & & Início & Final & Início & Final & Início & Final & Início & Final & Início & Final & Início & Final \\
\hline \multirow{2}{*}{ Fase 1} & 0,8 & $\mathrm{Sim}$ & 7,16 & 7,06 & 57,5 & 41,88 & 6,02 & 3,60 & 25,65 & 25,67 & 0,00 & 0,00 & 9,32 & 7,32 \\
\hline & 0,8 & Não & 7,22 & 7,14 & 63,75 & 56,25 & 6,11 & 2,70 & 25,36 & 25,38 & 0,00 & 0,00 & 8,25 & 8,55 \\
\hline \multirow{3}{*}{ Fase 2} & 1,6 & Sim & 7,21 & 7,29 & 11,28 & 2,20 & 5,65 & 6,04 & 13,21 & 13,90 & 0,00 & 0,00 & 30,2 & 28,73 \\
\hline & 0,8 & Sim & 7,41 & 7,40 & 59,6 & 42,30 & 6,18 & 8,30 & 13,77 & 14,10 & 0,00 & 0,00 & 11,39 & 10,73 \\
\hline & 0,8 & Não & 7,43 & 7,40 & 53,00 & 40,60 & 6,40 & 8,28 & 14,31 & 13,35 & 0,00 & 0,00 & 12,26 & 11,46 \\
\hline
\end{tabular}




\subsection{EXAMES MICROSCÓPICOS}

Os exames microscópicos foram realizados ao longo de todo o período de operação das duas fases, contemplando o início dos experimentos e todas as condições testadas. As microscopias não revelaram diferenças significativas entre as triplicatas com relação às morfologias analisadas. Por este motivo, as imagens apresentadas são representativas dos três reatores.

\subsubsection{Primeira fase}

Nas espumas retiradas no período inicial dos experimentos, quando era aplicada baixa concentração de solução de sulfeto $(\mathrm{N} / \mathrm{S}=4,8)$, e nitrato como receptor de elétrons, foi verificada a presença de diversas morfologias remanescentes do lodo de inóculo, em função da biomassa estar pouco selecionada. Foram encontrados filamentos, cocos, bacilos dispersos e aglomerados de bacilos, além de morfologias semelhantes à Methanosarcina. Tais morfologias também foram constatadas por Hirasawa (2008), em pesquisa que englobou a caracterização morfológica do lodo de inóculo proveniente de reator UASB tratando água residuária de abatedouro de aves (Avícola Dacar S/A - Tietê, SP), o qual corresponde ao mesmo lodo utilizado no presente trabalho. Além das morfologias citadas anteriormente, foi observada a presença de material inerte. Algumas das morfologias estão apresentadas na Figura 52. 


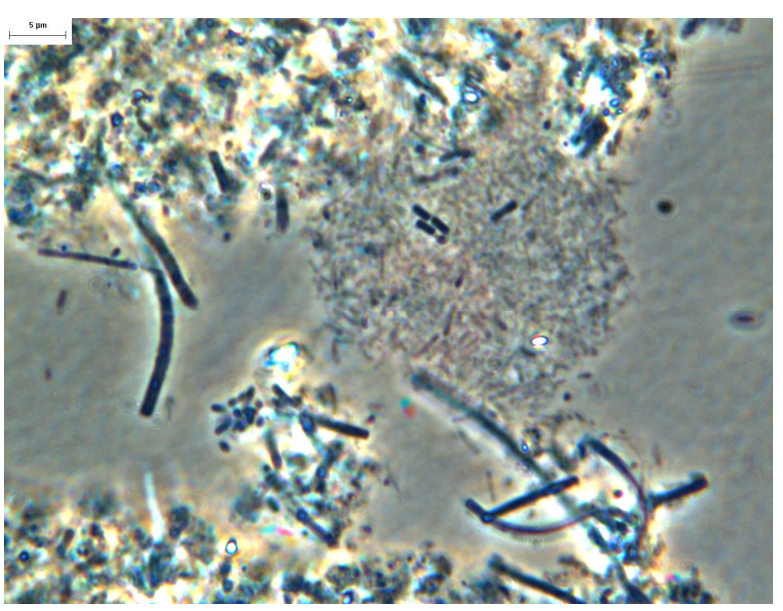

(a)

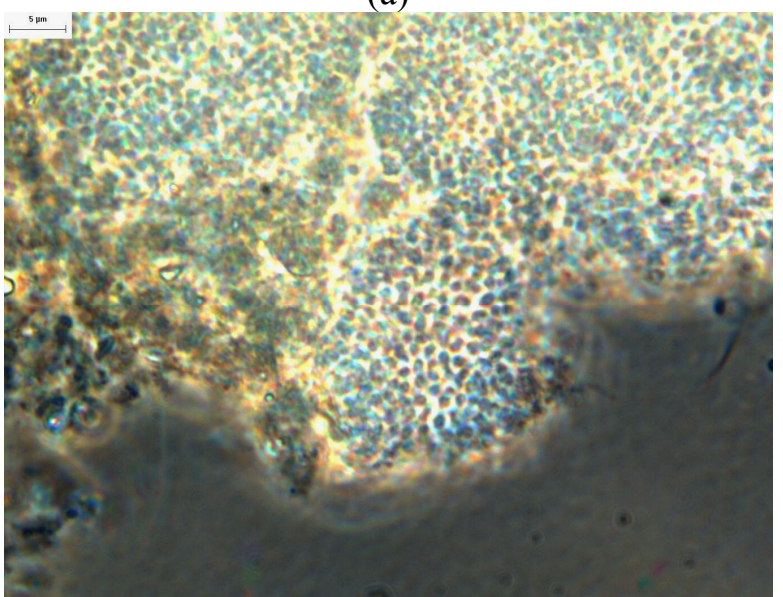

(c)

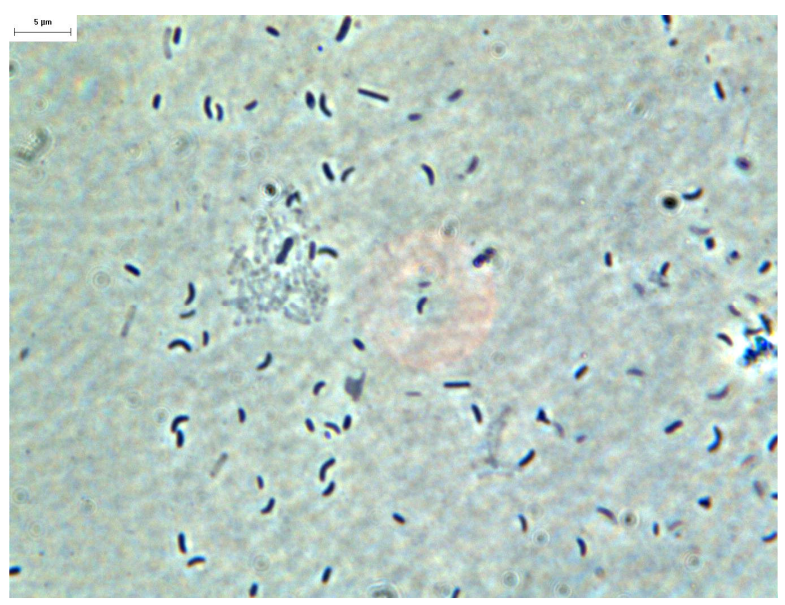

(b)

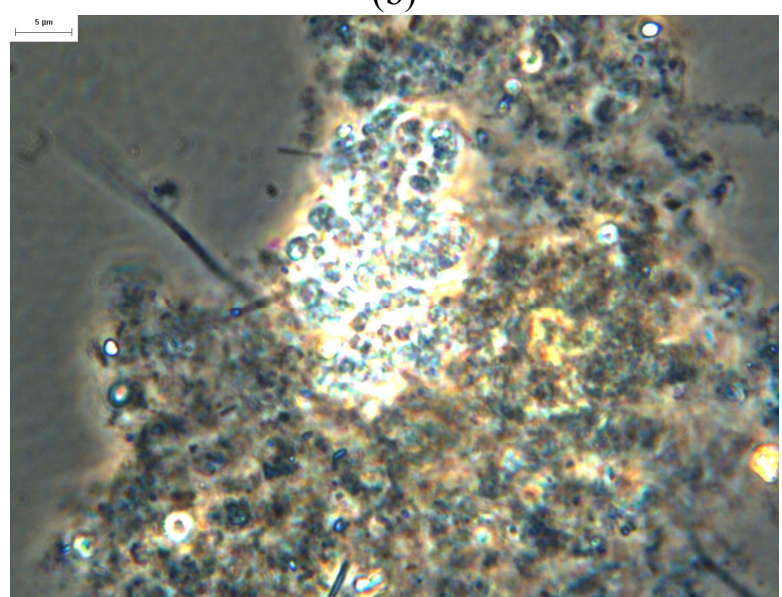

(d)

Figura 52 - Morfologias observadas sob microscopia óptica de contraste de fase no período inicial dos experimentos. (a) Filamentos, cocos, aglomerado de bacilos e material inerte, (b) bacilos dispersos, (c) cocos, (d) morfologia semelhante a Methanosarcina

Após 30 dias de operação, mantida a condição anterior, a biomassa estava mais selecionada, sendo observada a predominância de bacilos e alguns filamentos. Foram encontrados muitos aglomerados com coloração dourada, o que é indicativo da presença de enxofre elementar. Considerando os resultados operacionais, a alta densidade de bacilos é indicativa de morfologia semelhante às bactérias autotróficas desnitrificantes, como a espécie Thiobacillus denitrificans. Entretanto, deve-se ressaltar que, provavelmente, parte das formas bacilares é remanescente do lodo de inóculo, já que neste é encontrada muitas dessas morfologias. Algumas imagens estão apresentadas na Figura 53. 


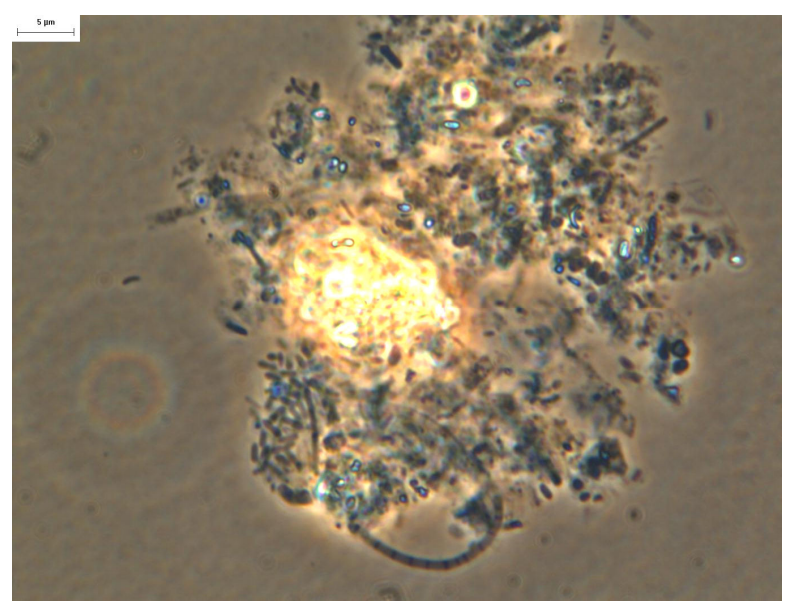

(a)

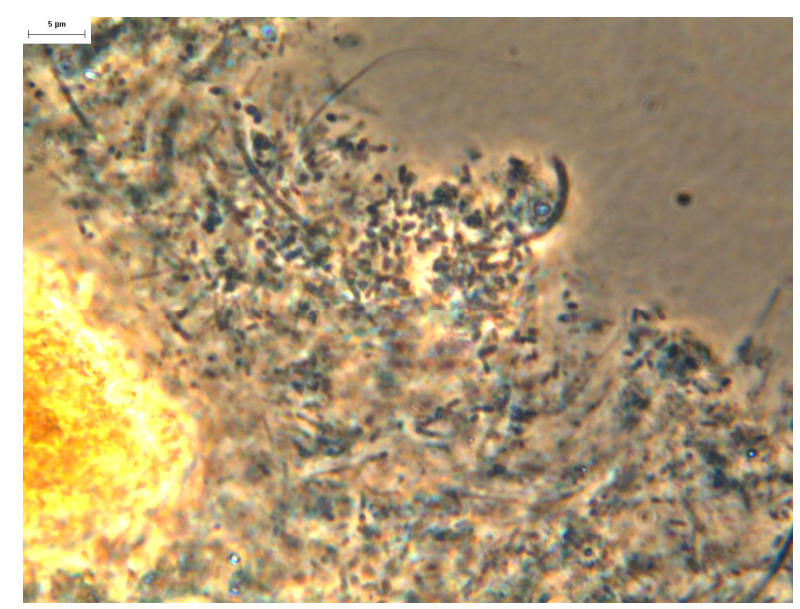

(b)

Figura 53 - Morfologias observadas sob microscopia óptica de contraste de fase após 30 dias de operação da primeira fase. (a) Aglomerado de bacilos próximos à formas semelhantes à enxofre elementar, (b) Aglomerado de bacilos próximos à formas semelhantes à enxofre elementar e alguns filamentos.

$\mathrm{Na}$ condição em que foi adicionada solução de sulfeto na concentração estequiométrica relativamente a nitrato $(\mathrm{N} / \mathrm{S}=1,6)$, as microscopias não revelaram morfologias muito diferentes das encontradas na condição anterior, sendo observados bacilos, alguns filamentos e formas semelhantes a enxofre elementar (Figura 54). A presença de bacilos com possíveis incrustações de enxofre também foi observada por Garbossa (2006), o qual avaliou a diversidade microbiana presente no RAAHF, que recebia efluente de reator UASB tratando esgoto sanitário, após o fornecimento de biogás.

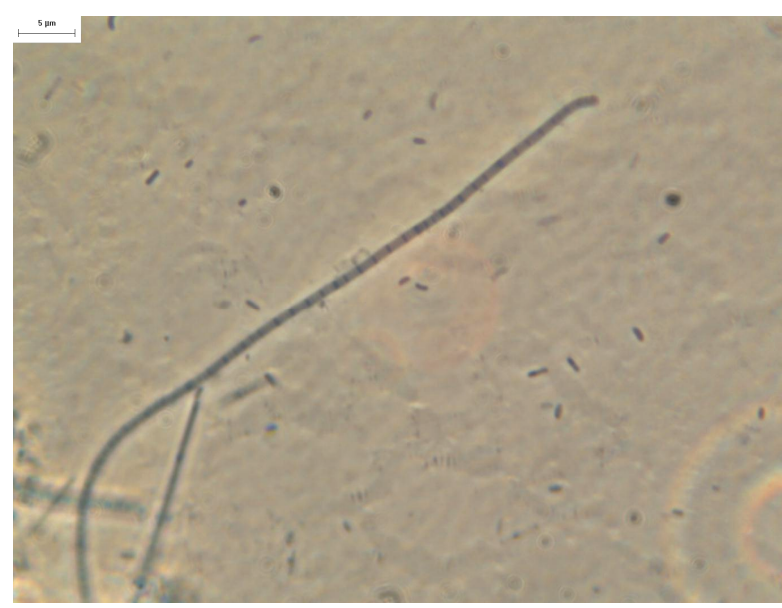

(a)

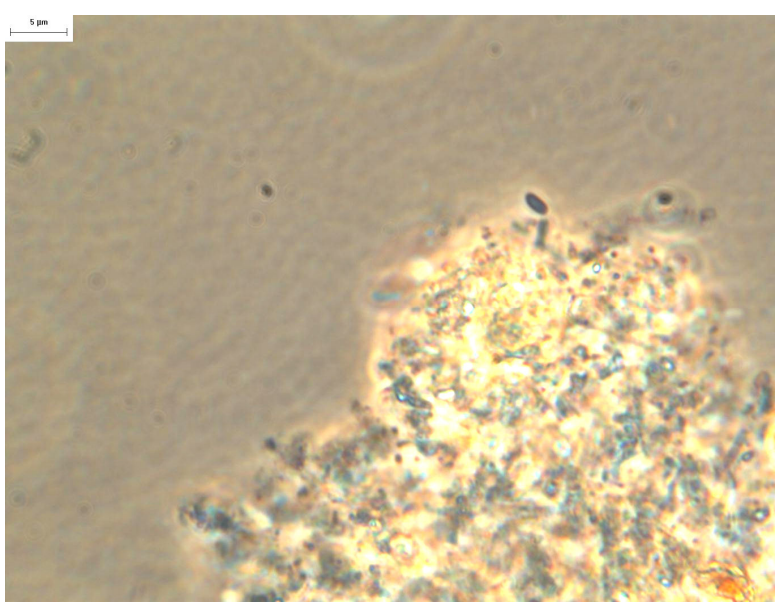

(b)

Figura 54 - Morfologias observadas sob microscopia óptica de contraste de fase na condição N/S equivalente a 1,6. (a) Bacilos dispersos e filamentos (b) Formas semelhantes à enxofre elementar 

ao tratamento de esgoto sanitário

$\mathrm{Na}$ condição N/S de 0,8 (excesso de sulfeto em relação à estequiometria relativa a nitrato), as microscopias foram realizadas após o choque de temperatura de $65^{\circ} \mathrm{C}$. Observouse que as células não foram destruídas pelo aquecimento, havendo a predominância de bacilos. Foi constatada maior quantidade de formas semelhantes a enxofre elementar, em função da maior concentração de sulfeto aplicada. Este fato está de acordo com os resultados obtidos pelas análises das formas de enxofre: a aplicação de sulfeto em excesso favoreceu a oxidação incompleta do mesmo, havendo maior formação de compostos intermediários de enxofre, como enxofre elementar. Algumas imagens estão apresentadas na Figura 55.

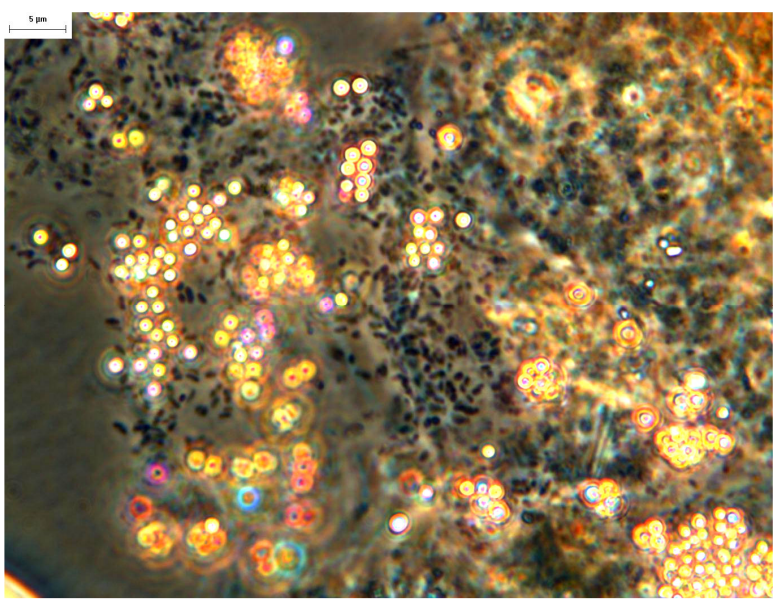

(a)

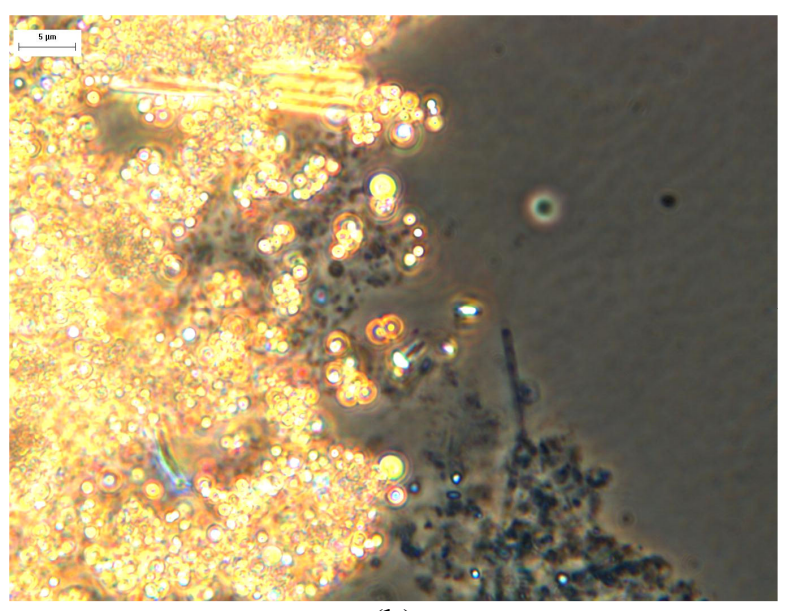

(b)

Figura 55 - Morfologias observadas sob microscopia óptica de contraste de fase na condição N/S equivalente a 0,8. (a) Bacilos e formas semelhantes à enxofre elementar (b) Formas semelhantes à enxofre elementar

As microscopias referentes aos experimentos em que foi aplicado nitrito como receptor de elétrons foram realizadas após o aquecimento de $100^{\circ} \mathrm{C}$, que ocasionou o término dos ensaios. Desse modo, as imagens registradas revelaram a destruição das células, sendo notada a presença de bacilos com morfologia descaracterizada, como ilustrado na Figura 56. 


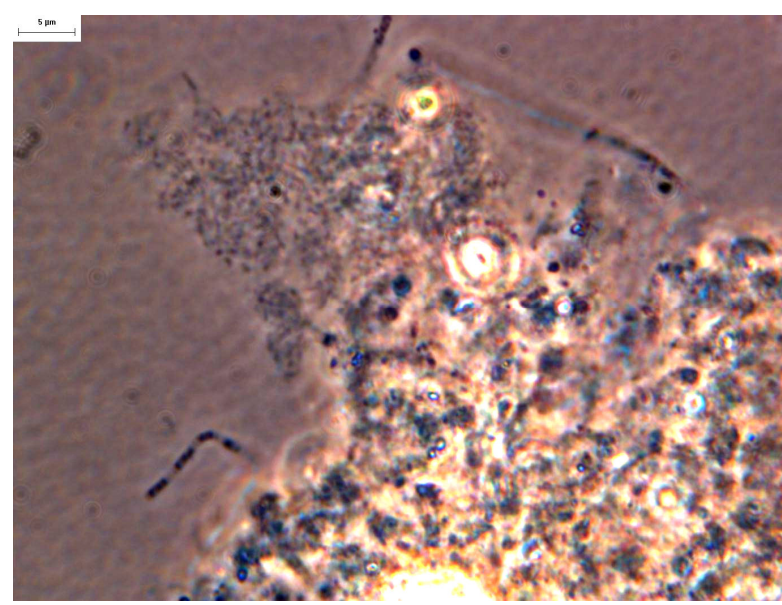

(a)

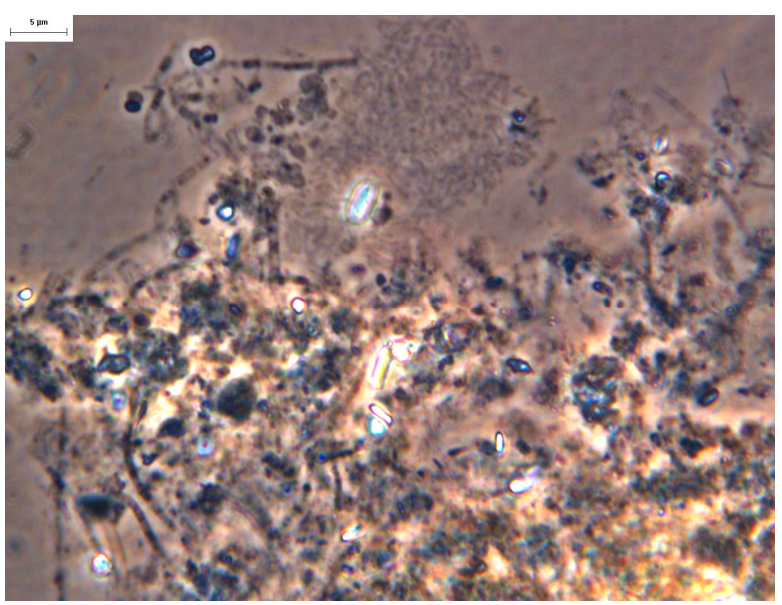

(b)

Figura 56 - Morfologias observadas sob microscopia óptica de contraste de fase na condição em que foi aplicado nitrito como receptor de elétrons, após o aquecimento de $100^{\circ} \mathrm{C}$. (a) e (b) bacilos com morfologia descaracterizada

\subsubsection{Segunda fase}

Com relação aos experimentos realizados na segunda fase do trabalho, as microscopias também revelaram a predominância de bacilos e alguns filamentos. Foram observadas poucas espiroquetas. Também foram visualizadas algumas formas indicativas de enxofre elementar. Algumas imagens estão apresentadas na Figura 57.

Comparando estas morfologias com as observadas na primeira fase, de maneira geral, parece ter havido maior quantidade de bacilos nos experimentos desta fase, sendo que, em grande parte, encontravam-se aglomerados. Entretanto, as incrustações de enxofre visualizadas foram mais escassas, apesar de os resultados das análises de concentração das formas de enxofre indicarem a formação de compostos intermediários. Este fato pode ser justificado pela menor concentração de solução de sulfeto aplicada nestes experimentos em comparação com os da fase anterior, e, assim, a formação de compostos intermediários de enxofre, como o enxofre elementar, foi menor. 


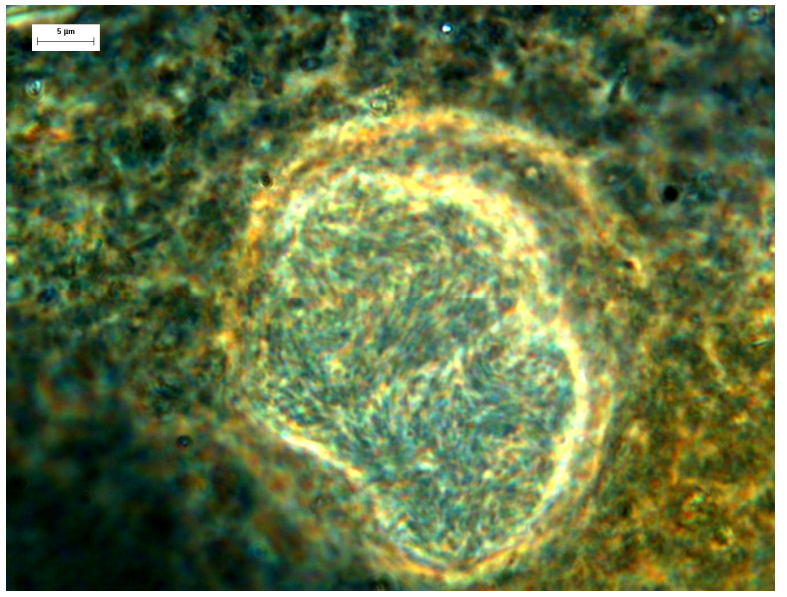

(a)

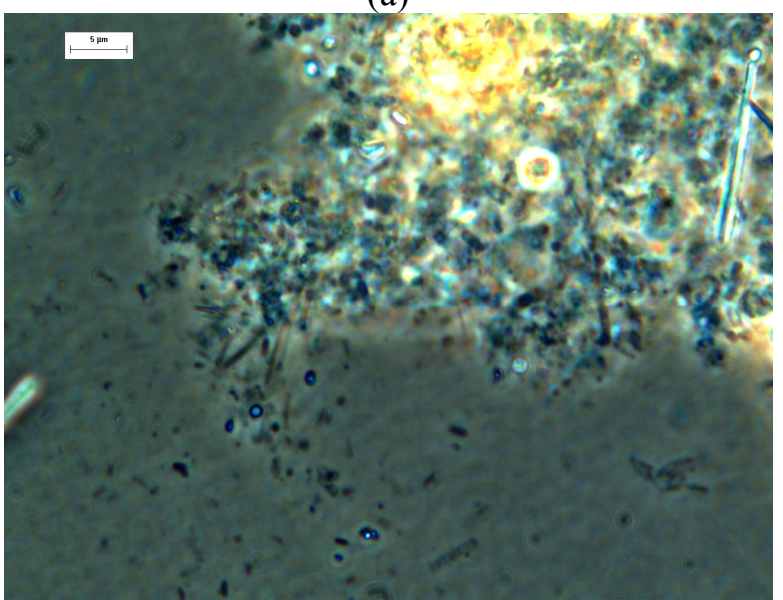

(c)

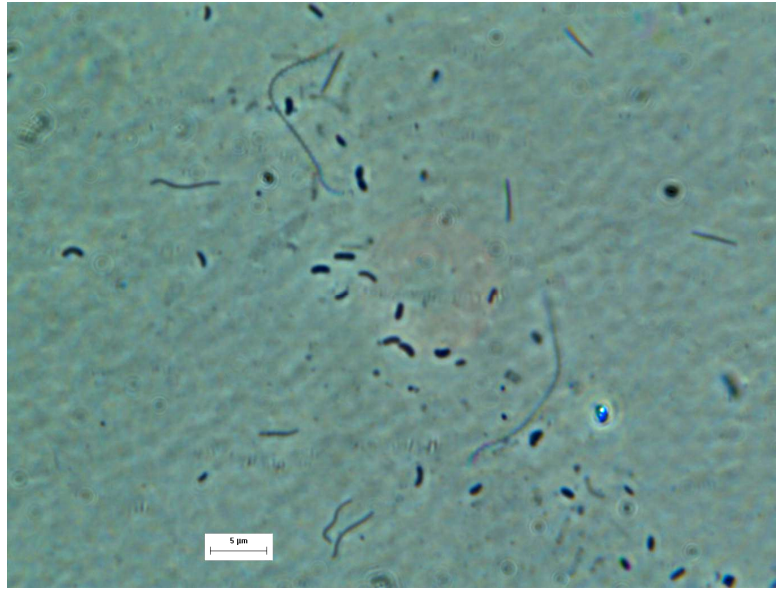

(b)

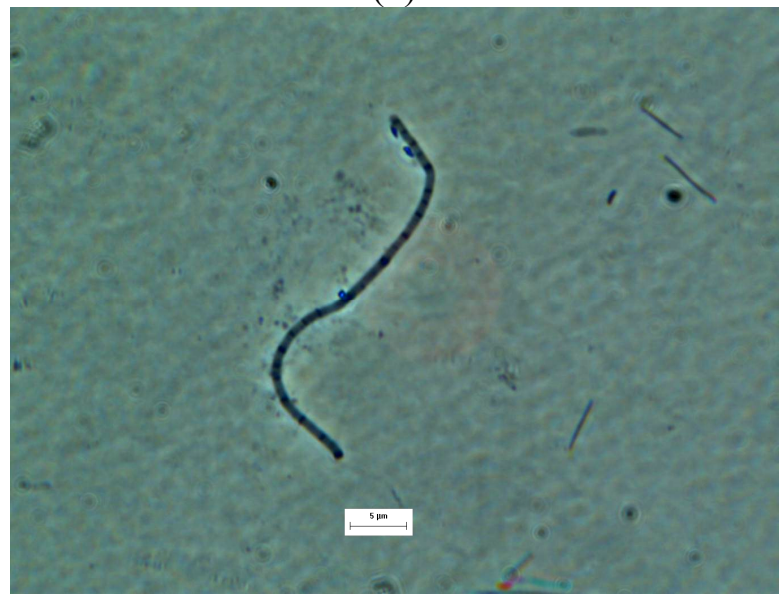

(d)

Figura 57 - Morfologias observadas sob microscopia óptica de contraste de fase referente aos experimentos realizados na segunda fase. (a) aglomerado de bacilos, (b) bacilos dispersos e espiroquetas, (c) bacilos e formas semelhantes a enxofre elementar, (d) filamento e espiroquetas

\subsection{DISCUSSÃO GERAL}

O principal resultado deste trabalho foi a constatação da viabilidade técnica da aplicação da desnitrificação autotrófica no tratamento de efluentes de reatores anaeróbios nitrificados e parcialmente nitrificados, em reatores operados em batelada contendo biomassa imobilizada em espumas de poliuretano, utilizando-se sulfeto como doador de elétrons.

Com relação à primeira fase da pesquisa, na qual os reatores foram alimentados com água residuária sintética nitrificada simulando efluente de reatores anaeróbios tratando esgoto sanitário, foi detectada a desnitrificação completa tanto com o uso de nitrato quanto de nitrito como receptores de elétrons. Todavia, a remoção completa de compostos oxidados de 
nitrogênio só ocorreu quando foram aplicadas relações N/S inferiores à estequiométrica, ou seja, quando foi injetado sulfeto em excesso. Quando a condição de N/S aplicada foi correspondente à estequiometria relativamente aos compostos oxidados de nitrogênio (nitrato ou nitrito) e sulfeto, observou-se acúmulo de nitrito ao longo dos ciclos. Existiram evidências de formação de compostos intermediários de enxofre, principalmente quando foi aplicado sulfeto em excesso (baixas relações N/S), o que comprova que os produtos finais da oxidação do sulfeto podem ser afetados pela relação N/S. Os níveis de concentração de nitrogênio amoniacal entre os ciclos não indicaram a ocorrência de RDNA. O pH se manteve próximo a neutralidade durante todo período de operação, com aplicação de ambos os receptores de elétrons utilizados, exceto quando a concentração de bicarbonato injetada foi insuficiente, na condição N/S equivalente a 4,8 .

$\mathrm{Na}$ segunda etapa do trabalho, na qual a alimentação dos reatores foi realizada com mistura de água residuária sintética nitrificada e efluente real de reator anaeróbio tratando água residuária de abatedouro de aves, também foi constatada a desnitrificação autotrófica com uso de sulfeto como doador de elétrons e aplicação de nitrato como receptor; entretanto, o processo ocorreu na relação $\mathrm{N} / \mathrm{S}$ correspondente à estequiometria relativa a nitrato e sulfeto, e não houve formação significativa de sulfato, nem mesmo ao final do ciclo. Este fato é um indicativo de que existiram outras fontes de elétrons para a redução completa de nitrato, sem acúmulo de nitrito, as quais provavelmente estavam presentes no efluente de abatedouro aves, proveniente de reator UASB, utilizado. Além disso, todo o sulfeto foi consumido muito antes do término da desnitrificação completa. Os altos níveis de concentração de nitrogênio amoniacal foram atribuídos à água residuária de reator anaeróbio tratando efluente de abatedouro de aves utilizada na alimentação, a qual contém originalmente alto teor deste composto. Com relação ao pH, foi necessária a elevação da concentração de bicarbonato para 

ao tratamento de esgoto sanitário

aumentar o poder de tamponamento do meio, e desse modo, manter os valores de $\mathrm{pH}$ próximos de 7,0.

Os valores médios dos parâmetros analisados no início e final de 24 horas, em ambas as fases, estão apresentados na Tabela 15, na qual também está especificado o receptor de elétrons empregado.

Tabela 15 - Valores médios dos parâmetros monitorados nas duas fases do trabalho, para cada receptor de elétrons utilizado, medidos no início e ao final de 24 horas.

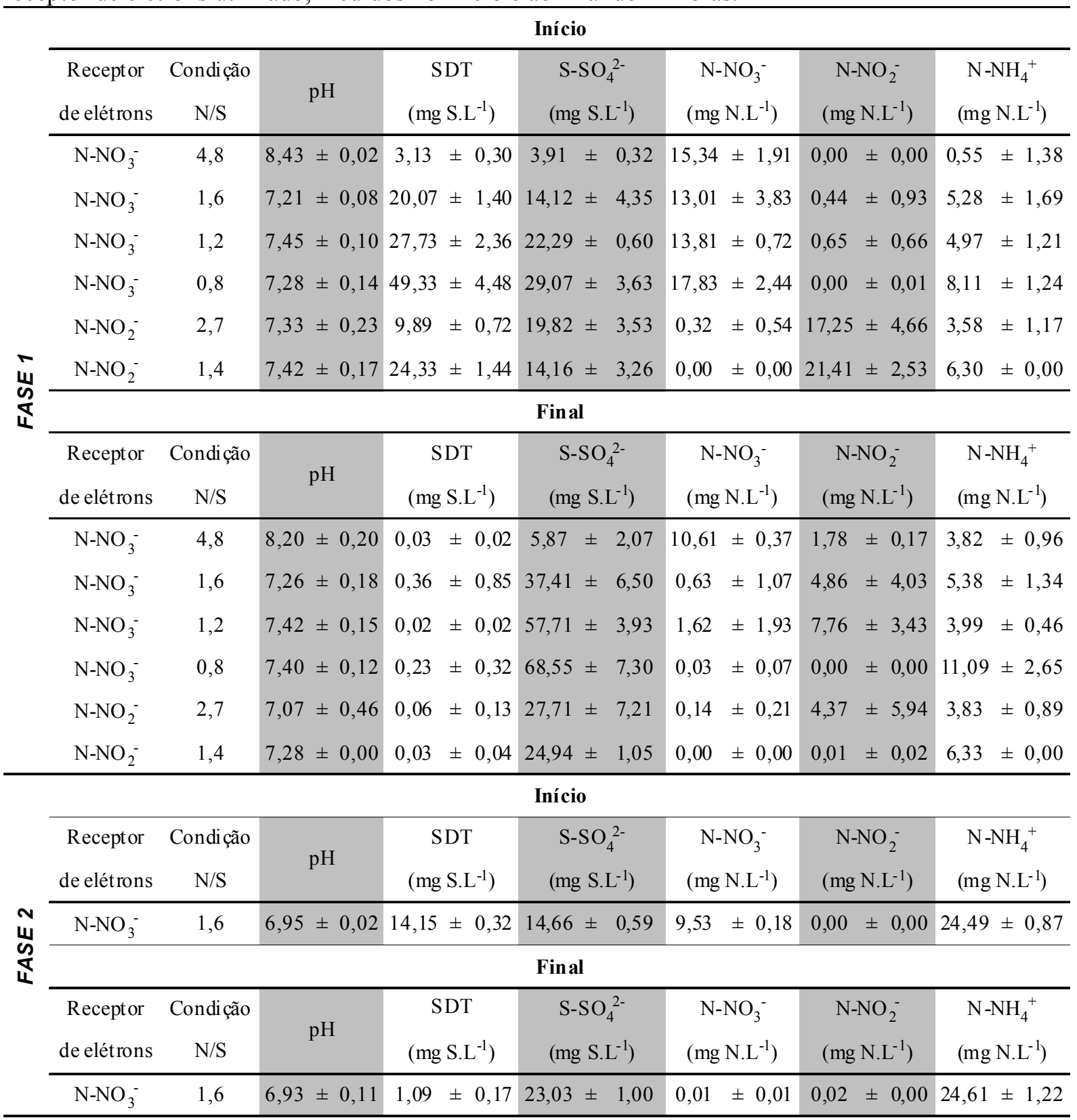


A modelagem cinética relativa às reações bioquímicas, de maneira geral, sofreu influência dos fenômenos de transferência de massa, de forma que as velocidades de remoção de nitrogênio foram limitadas efetivamente pelas resistências à transferência de massa externa e interna. A exceção ocorreu no segundo perfil da primeira fase, empregando nitrato como receptor de elétrons, em que a resistência à transferência de massa intraparticular não teve efeito significativo no processo. Este fato deve ter ocorrido em função do choque térmico a que foram submetidos os reatores, e, de alguma forma, este aquecimento reduziu as limitações impostas pela resistência à difusão intraparticular. Neste caso, o modelo cinético ajustado foi de ordem zero, ao contrário do que ocorreu nos outros perfis das duas fases, em que o modelo de primeira ordem foi mais adequado.

Desse modo, as resistências à transferência de massa interna e externa tiveram influência sobre a ordem do modelo cinético ajustado. Além disso, foi observada desnitrificação completa em praticamente todos os ensaios, ou seja, houve consumo completo do substrato, comportamento que não ocorre para modelos de decaimento exponencial de primeira ordem, relativo apenas às reações bioquímicas, e é característico de modelos de ordem zero. Para reforçar este fato, Garbossa (2006) obteve modelo cinético de ordem zero relativo à remoção de nitrogênio em experimentos em batelada contendo biomassa imobilizada em matrizes cúbicas de espuma de poliuretano. A água residuária utilizada consistiu em efluente sanitário sintético nitrificado e o doador de elétrons fornecido foi apenas sulfeto. Segundo o autor, os efeitos da resistência externa à transferência de massa foram minimizados em função da agitação de $150 \mathrm{rpm}$ utilizada.

Sendo assim, há indícios de que, se as resistências à transferência de massa fossem minimizadas no presente experimento, os modelos cinéticos de remoção de nitrogênio ajustados seriam de ordem zero. E, portanto, as velocidades das reações bioquímicas não seriam afetadas pela concentração dos substratos. 

ao tratamento de esgoto sanitário

Os dados relativos à modelagem cinética de todos os ensaios realizados nas duas fases e nas respectivas condições testadas estão apresentados, de forma geral, na Tabela 16.

Tabela 16 - Valores médios dos parâmetros relativos à modelagem cinética, obtidos para os três reatores, contemplando as duas fases do trabalho e os dois receptores de elétrons utilizados.

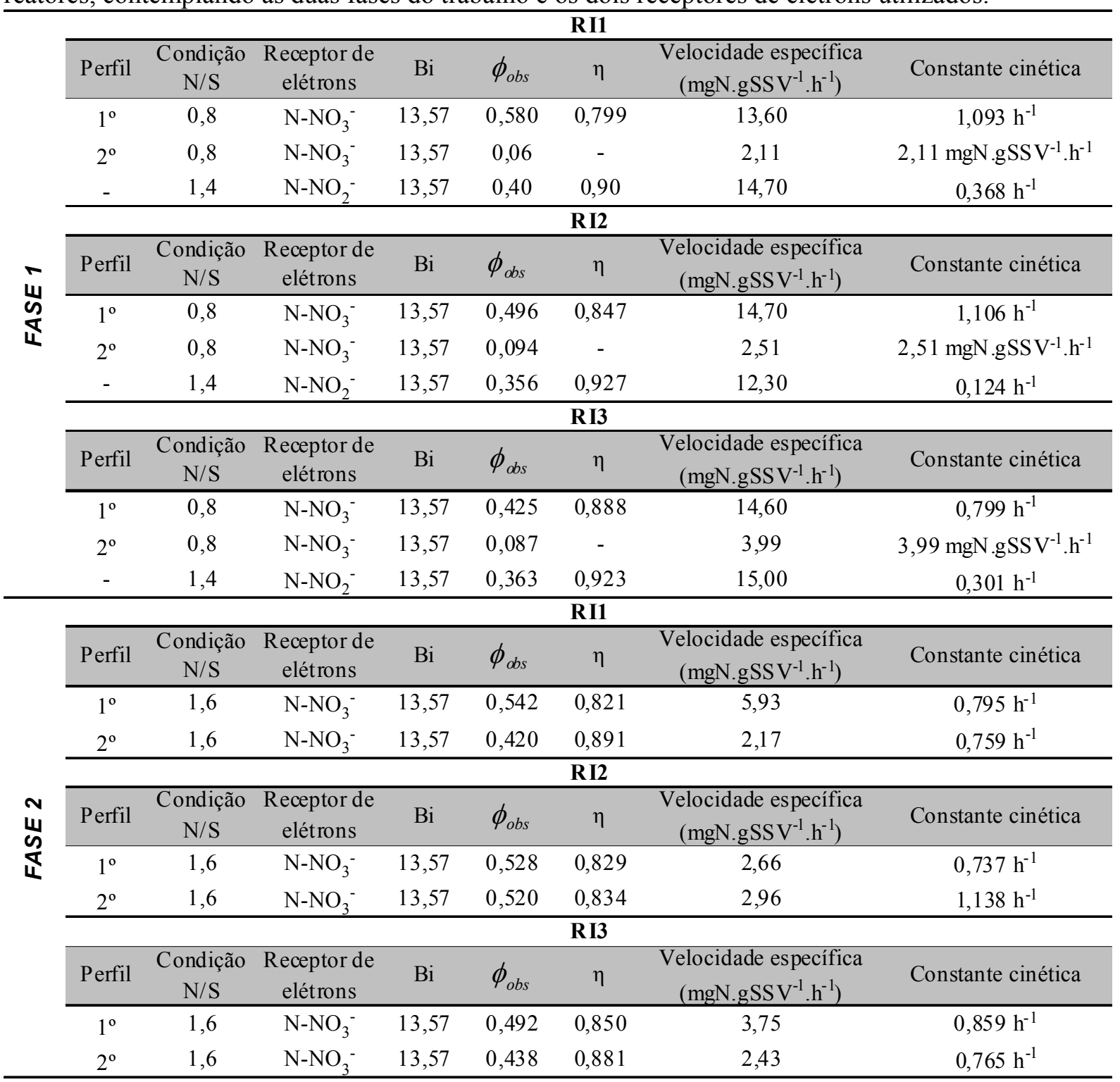

As microscopias revelaram, de forma geral, a predominância de bacilos e presença de incrustações de enxofre elementar, sendo estas últimas mais evidentes quando as concentrações de sulfeto aplicadas eram maiores. Este fato está em concordância com os resultados obtidos nas análises de concentração das formas de enxofre, que indicaram maior 
formação de compostos intermediários de enxofre, como enxofre elementar, quando era injetado sulfeto em excesso. 


\section{Conclusões}

A principal conclusão deste trabalho foi a constatação da viabilidade técnica da aplicação da desnitrificação autotrófica usando sulfeto como doador de elétrons no tratamento de efluentes de reatores anaeróbios nitrificados e parcialmente nitrificados, empregando biomassa imobilizada.

Os resultados obtidos também permitem concluir que:

$\checkmark$ Nos reatores alimentados com efluente sanitário sintético nitrificado, a desnitrificação autotrófica completa ocorreu de maneira estável somente quando a concentração dos receptores de elétrons, nitrato ou nitrito, foi limitante, o que corresponde a baixas relações $\mathrm{N} / \mathrm{S}$

$\checkmark$ Nos reatores alimentados com água residuária parcialmente nitrificada (mistura de efluentes), a desnitrificação autotrófica completa ocorreu de maneira estável quando as concentrações de nitrato e sulfeto aplicadas foram equivalentes à estequiometria com base nas reações químicas;

$\checkmark$ Os produtos finais da oxidação do sulfeto na desnitrificação autotrófica foram afetados pela relação N/S, sendo que a aplicação de sulfeto em excesso, com relação à estequiometria relativa a nitrato e nitrito, promoveu maior formação de compostos intermediários do enxofre;

$\checkmark$ Existiram evidências de que a água residuária de reator anaeróbio tratando efluente de abatedouro de aves possui fontes adicionais de elétrons para a redução de nitrato e nitrito associada à desnitrificação com emprego de sulfeto; 
$\checkmark$ Os valores do fator de efetividade, módulo de Thiele e número de Biot, indicam que as resistências à transferência de massa externa e intraparticular foram significativas nas condições operacionais estudadas;

$\checkmark$ De modo geral, a cinética de remoção de nitrogênio seguiu modelo de decaimento exponencial de primeira ordem; entretanto, evidências comprovam que este fato ocorreu em função dos fenômenos de transferência de massa e tal cinética de remoção poderia seguir modelo de ordem zero, ou seja, a velocidade de remoção do substrato é independente da concentração do mesmo;

$\checkmark$ Os parâmetros cinéticos aparentes obtidos revelaram que, de maneira geral, o processo teve melhor desempenho utilizando nitrato como receptor de elétrons, ao invés nitrito;

$\checkmark$ As máximas velocidades específicas aparentes de remoção de nitrogênio foram da ordem de $15 \mathrm{mgN} \cdot \mathrm{gSSV}^{-1} \cdot \mathrm{h}^{-1}$, tanto com o emprego de nitrato como de nitrito como receptor de elétrons, quando os reatores foram alimentados com efluente sanitário sintético nitrificado;

$\checkmark$ A máxima velocidade específica aparente de remoção de nitrogênio na forma de nitrato atingiu valor próximo a $6 \mathrm{mgN} \cdot \mathrm{gSSV}^{-1} \cdot \mathrm{h}^{-1}$, quando os reatores foram alimentados com água residuária parcialmente nitrificada;

$\checkmark$ As microscopias realizadas revelaram, de maneira geral, a predominância de bacilos, aglomerados e dispersos, e formas semelhantes a enxofre elementar. 
Utilização de sulfeto como doador de elétrons para a desnitrificação autotrófica aplicada 101 ao tratamento de esgoto sanitário

\section{SUGESTÕES}

A partir dos resultados obtidos na presente pesquisa, são propostas as seguintes sugestões para trabalhos futuros relacionados à desnitrificação autotrófica empregando sulfeto como doador de elétrons:

$\checkmark$ Determinar a cinética intrínseca do processo, na qual os parâmetros cinéticos são obtidos em condições cujos fenômenos de transferência de massa são desprezíveis;

$\checkmark$ Avaliar o comportamento do processo na presença de efluente real de reator anaeróbio tratando esgoto sanitário, com o emprego do sulfeto presente na fase líquida do efluente e no biogás;

Estudar o comportamento do processo em reatores com fluxo contínuo;

Investigar e identificar a população microbiana envolvida no sistema. 


\section{REFERÊNCIAS BIBLIOGRÁFICAS}

Anh, Y. (2006) Sustainable nitrogen elimination biotechnologies: A review. Process Biochemistry, v.41, p.1709-1721.

Bailey, J.E. e Ollis, D.F. (1986). Biochemical Engeneering Fundamentals. 2ed, McGraw-Hill Book Company, 984p

Bartchelor, B. e Lawrence, A.W. (1978). A kinetic model for autotrophic denitrification using elemental sulfur. Water Research, v.12, p. 1075-1084.

Beristain-Cardoso, R.; Sierra-Alvarez, R.; Rowlette, P.; Flore, E. R.; Gómez, J.; Field, J. A. (2006). Sulfide oxidation under chemolithoautotrophic denitrifying conditions. Biotechnology and Bioengineering, v.95, n.6, p.1148-1157.

Bringi, V. e Dale, B.E. (1990). Experimental and theoretical evidence for convective nutrient transport in an immobilized cell support. Biotechnology Progress, v.6, n.3, p.205-209.

Brunet, R. C. e Garcia-Gil, L. J. (1996). Sulfide-induced dissimilatory nitrate redution to ammonia in anaerobic freshwater sediments. FEMS Microbiology Ecology, v. 21, p. 131138.

Callado, N.H. e Foresti, E. (2000). Tratamento de esgoto doméstico com remoção de nitrogênio e fósforo em reatores seqüenciais em batelada. In: Congresso Interamericano de Ingenieria Sanitaria y Ambiental. Anais. Porto Alegre, AIDIS. CD-ROM.

Campos, J.L.; Carvalho, S.; Portela, R.; Mosquera-Corral, A.; Méndez, R. (2008). Kinetics os denitrification using sulphur compounds: effects of $\mathrm{S} / \mathrm{N}$ ratio, endogenous and exogenous compounds. Bioresource Technology, v.99, p. 1293-1299.

Chernicharo, C. A. L. (2006). Post-treatment opitions for the anaerobic treatment of domestic wastewater. Reviews in Environmental Science and Bio/Technology. v. 5, p. 73-92.

Chung, J. e Bae, W. (2002). Nitrite reduction by a mixed culture under conditions relevant to shortcut biological nitrogen removal. Biodegradation, v.13, p.163-170.

Droste, R.L. e Kennedy, K.J. (1987). Steady state kinetics of anaerobic downflow stationary fixed film reactors. Water Science Technology, v.19, p.275-285.

Foresti, E.; Zaiat, M.; Vallero, M. (2006). Anaerobic processes as the core technology for sustainable domestic wastewater treatment: Consolidated applications, new trends, perspectives, and challenges. Reviews in Environmental Science and Bio/Technology, v.5, p. 3-19.

Garbossa, L. H. P. (2006). Avaliação de sistemas anaeróbio-aeróbio com biomassa imobilizada para remoção de matéria carbonácea e nitrogênio de esgoto sanitário e uso de $\mathrm{H}_{2} \mathrm{~S}$ na desnitrificação. 125p. Tese (Doutorado) - Escola de Engenharia de São Carlos, Universidade de São Paulo.

Gommers, P.J.; Buleveld, W.; Zuiderwijk, F.J; Kuenen, J.G. (1988). Simultaneous sulfide and acetate oxidation in a denitrifying fluidized bed reactor. Water Research, v.22, p.10851095.

Henze, M.; Harremoes, P.; Jassen, J.C.; Arvin, E. (1997). Wastewater Treatment. Biological and Chemical Processes. 2 ed. German: Springer. 
Utilização de sulfeto como doador de elétrons para a desnitrificação autotrófica aplicada 103 ao tratamento de esgoto sanitário

Her, J. e Huang, J. (1995). Influences of carbon source and C/N ratio on nitrate/nitrite denitrification and carbon breakthrough. Bioresource Technology. v. 54, p 45-51.

Hirasawa, J.S. (2008). Avaliação da metanogênese e sulfetogênese na presença de oxigênio, sob diferentes relações etanol/sulfato, utilizando técnicas da Biologia Molecular. 114p. Tese (Doutorado) - Escola de Engenharia de São Carlos, Universidade de São Paulo.

Hulshoff Pol, L. W.; Lens, P. N. L.; Stams, A. J. M.; Lettinga, G. (1998). Anaerobic treatment of sulphate-rich wastewaters. Biodegradation, v.9, p 213-224.

Iamamoto, C. Y. (2006). Remoção de nitrogênio de águas residuárias com elevada concentração de nitrogênio amoniacal em reator contendo biomassa em suspensão operado em bateladas seqüenciais e sob aeração intermitente. São Carlos. 139p. Tese (Doutorado) - Escola de Engenharia de São Carlos, Universidade de São Paulo.

Janssen, A. J. H.; Lettinga, G.; Keizer, A. (1999). Removal of hydrogen sulphide from wastewater and waste gases by biological conversion to elemental sulphur: Colloidal and interfacial aspects of biologically produced sulphur particles. Colloids and Surfaces: A Physicochemical and Engineering Aspects, v.151, p.389-397.

Kalyuzhnyi, S.; Gladchenko, M.; Mulder, A.; Versprille, B. (2006) DEAMOX-New biological nitrogen removal process based on anaerobic ammonia oxidation coupled to sulphide-driven conversion of nitrate into nitrite. Water Research, v. 40, p. 3637-3645.

Khin, T. e Annachhatre, A.P. (2004). Novel microbial nitrogen removal processes. Biotechnology Advances, v.22, p.519-532.

Kim, I. S. e Park, W. (2004). Respirometric monitoring for the determination effective height and reaction rate constant in up-flow autotrophic denitrification reactor packed with sulfur. Environmental Monitoring and Assessment, v.104, p 221-234.

Kimura, K.; Nakamura, M.; Watanabe, Y. (2002). Nitrate removal by a combination of elemental súlfur-based denitrification and membrane filtration. Water Research, v.36, p. $1758-1766$.

Kleerebezem, R. e Mendez, R. (2002). Autotrophic denitrification for combined hydrogen sulfide removal from biogas and pos-denitrification. Water Sci.Techn., v.45, n.10, p.349356.

Koenig, A. e Liu, H. (2000). Kinetic model for autotrophic denitrification in sulphur packedbed reactors. Water Reaserch, v.35, n.8, p 1969-1978.

Krishna, K. R. e Philip, L. (2005). Studies on removal of nitrogen dioxide using Thiobacillus denitrificans immobilized biotrickling filter. Journal of Clean Technology and Environmental Policy, v. 7, n.4, p. 285-293.

Krishnakumar, B. e Manilal, V. B. (1999). Bacterial oxidation of sulphide under denitrifying conditions. Biotecnhology Letters, v. 21, p. 437-440.

Lee, H. J.; Bae J. H.; Cho, K. M. (2001). Simultaneous nitrification and denitrification in a mixed methanotrophic culture. BiotechnologyLetters, v. 23, p. 935-941.

Mahmood, Q.; Zheng, P.; Cai, J.; Wu, D.; Hu, B.; Li, J. (2007). Anoxic sulfide biooxidation using nitrite as electron acceptor. Journal of Harzadous Materials, v.147, p.249-256.

Manconi, I.; Carucci, A; Lens, P. (2007). Combined removal of sulfur compounds and nitrate by autotrophic denitrification bioaugmented activated sludge system. Biotechnology and Bioengineering, v.18, n.3, p.551-560. 
Metcalf e Eddy. Inc. (2003). Wastewater Engineering - Treatment and reuse. 4 ed. New York, McGraw-Hill Internacional edition, 1819p.

Moon, H. S.; Ahn, K. H.; Lee, S.; Nam, K.; Kim, J. Y. (2004). Use of autotrophicsulfuroxidizers to remove nitrate from bank filtrate in a permeable reactive barrier system. Environ. Pollut.,v.129, p. 499-507.

Oh, S. E.; Bum, M. S.; Yoo, Y. B.; Zubair, A.; Kim. I. S. (2002) Nitrate removal by simultaneous sulfur utilizing autotrophic and heterotrophic denitrification under different organics and alkalinity conditions: batch experiments. Water Sci. Techn. V.47, n.1, p.237244.

Pérez, R.; Galí, A.; Dosta, J.; Mata-Alvaréz, J. (2007). Biological nitrógeno removal (BNR) using sílfides for autotrophic denitrification in a sequencing batch reactor (SBR) to treat reject water. Ind. Eng. Chem. Res., v. 46, p. 6646-6649.

Perry, R. H. e Chilton, C. C. (1985). Chemical Engineers Handbook. 5 ed, McGraw-Hill, New York.

Pochana, K. e Keller, J. (1999). Study of factors affecting simultaneous nitrification and denitrification (SDN), Water Science and Technology, v. 39, n. 6, p. 61-68.

Reyes-Ávila, J.; Razo-Flores, E.; Gómez, J. (2004). Simultaneous biological removal of nitrogen, carbon and sulfur by denitrification, Water Research, v. 38, p. 3313-3321.

Ros, M. (1995). Denitrification kinetics in an activated sludge system, Water Science Technology, v. 32, p. 323-330.

Schmidt, I.; Sliekers, O.; Schmid. M.; Bock, E.; Fuerst, J.; Gijs Kuenen, J.; Jetten, M. S. M.; Strous, M. (2003). New concepts of microbial treatment processes for the nitrogen removal in wastewater. FEMS Microbiology Reviews, v.27, p.481-492.

Sierra-Alvarez, R; Beristain-Cardoso, R.; Salazar, M.; Gómez, J.; Razo-Flores, E.; Field, A. J. (2007). Chemolitotrophic denitrification with elemental sulfur for groundwater treatment. Water Research, v.41, p.1253-1262.

Soares, M. I. M. (2002). Denitrification of groundwater with elementar sulfur, Water Research, v. 36, p. 1392-1395.

Speece, R. E. (1996). Anaerobic biotechnology for industrial wastewater. Ed. Archae Press, Nashville, Tennessee, 394p.

Standard Methods for the Examination of Water and Wastewater (2005). 20th ed. American Public Health Association / American Water Works Association / Water Environment Federation, Washington, DC, USA.

Vaiopoulou, E.; Melidis, P.; Aivasidis, A. (2005). Sulfide removal in wastwater from petrochemical industries by autotrophic denitrification. Water Research, v.39, p. 41014109.

Van Handeel, A. e Marais, G. (1999). O comportamento do sistema de lodo ativado: Teoria e aplicações para projetos e operação, Epgraf, Campina Grande, 472p.

Verstraete, W. e Philips, S. (1998). Nitrification-denitrification process and technologies in new contexts. Environmental Pollution, v.102, p.717-726.

Vieira, L. G. T. (1996). Estimativa de parâmetros cinéticos intrínsecos de utilização de substrato por lodo anaeróbio imobilizado. 63p. Dissertação (Mestrado) - Escola de Engenharia de São Carlos, Universidade de São Paulo. 
Utilização de sulfeto como doador de elétrons para a desnitrificação autotrófica aplicada 105 ao tratamento de esgoto sanitário

Villaverde, S. (2004). Recent developments on biological nutrient removal processes for wastewater treatment. Reviews in Environmental Science and Bio/Technology, v.3, p.171183.

Welty, J. R.; Wicks, C. E.; Wilson, R. E. (1984). Fundamentals of momentum, heat and mass transfer. 3ed, John Wiley e Sons, New York.

Wilhelm, E.; Battino, R.; Wilcock, R. J. (1977). Low-pressure solubility of gases in liquid water.Chem. Rev, v.77, p.219-262.

Zaiat, M.; Veira, L. G. T.; Foresti, E. (1996). Intrinsic kinetic parameters of substrate utilization by immobilized anaerobic sludge. Biotechnology and bioengineering, v. 53, p. 220-225.

Zhang, T. C. e Lamp, D. G. (1999). Sulfur: limestone autotrophic denitrification processes for treatment of nitrate-contaminated water: batch experiments. Water Research, v.33, n.3, p. 599-608. 